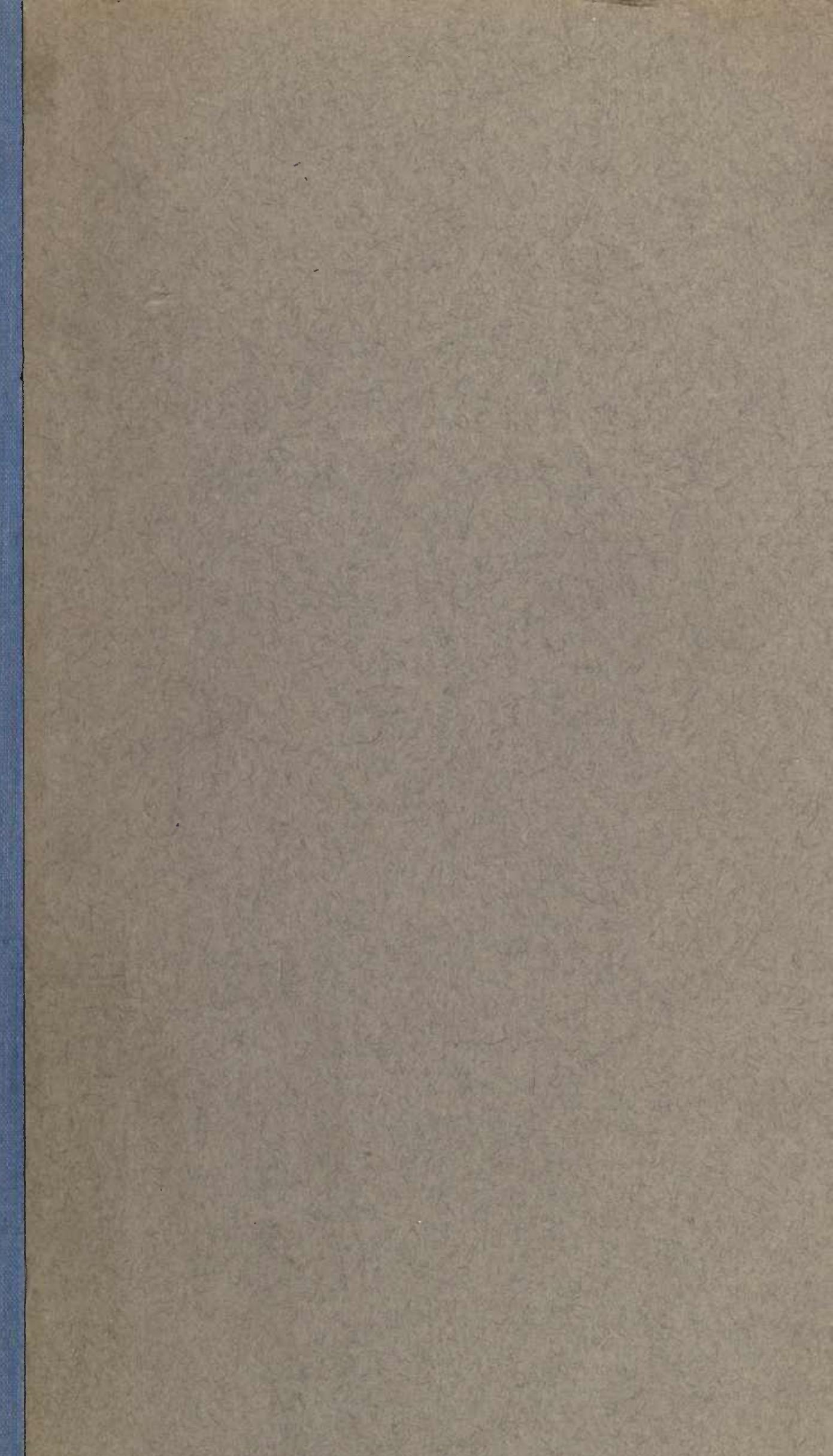




\section{BERKELEY LIBRARY UNIVERSITY OF CALIFORNIA}

\section{c.s.5 \\ B \\ ex.}






\title{
Check List of Books
}

\author{
$\mathrm{ON}$
}

Angling, Fish, Fisheries

Fish-Culture, Etc.

IN THE

Library of

DANIEL B. FEARIN G

Member of Suffolk Club, South Haven, L. I.; West Island Club, R. I.; Triton Club, P. Q., and Life Member of the American Fish Culturists' Association.

NEWPORT, R. I.

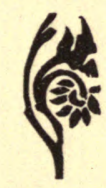

NEW YORK

Printed for Private Distribution

I 901 
JOHN POLHEMUS PRINTING COMPANY, I2I FULTON STREET, NEW YORK.

GASE

$\mathrm{B}$

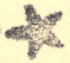


Lor Teury thorpe. Eop irit
vacuice

Dawiel B. Aarcicǵp

bugfent. R.I. apprecialive tauks. elayg.1901. 


\section{NOTE.}

HE collecting of books treating on special subjects has been prevalent for a long series of years. I doubt if any subject has given more pleasure to the collector, than that afforded the seeker after works on Angling, Fish, Fishing, Fish-Culture, Fisheries, and kindred subjects.

The numerous writers on the Art of Angling from the earliest times to the present, testify to its fascination and popularity. No other branch of out-door sport has ever called forth such efforts in its praise, such minute directions for its pursuit, nor in such quantity, as has been given to the "gentle art."

This collection, commenced in 1890, has grown steadily, till it now numbers over two thousand titles. No attempt has been made to collect the many editions of that famous pastoral, "The Complete Angler," by Walton and Cotton. Yet enough are included to represent their contribution to the literature of Angling. Some of the titles included here will be searched for in vain in other collections. This list has been made to have in a convenient form a check against duplication while searching for new titles.

Twenty-five copies only printed for private distribution.

NEwPoRT, R. I., April, 1901.
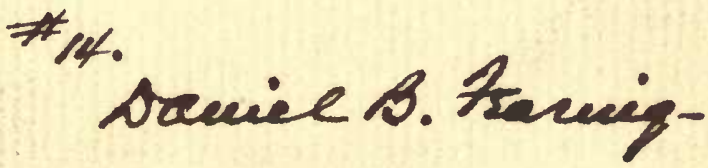




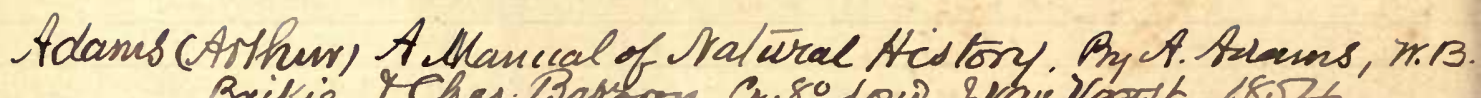
Beitie YChas. Pakboon G.80 dow. gvain Vardt, 1804

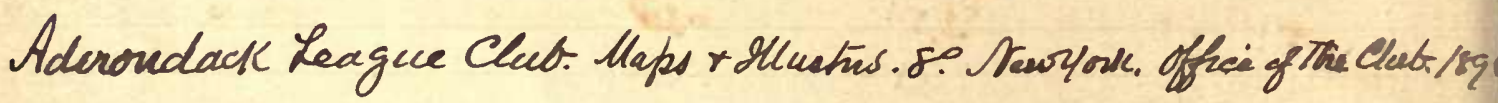




\section{CHECK LIST.}

A BBOT' (CHAS. C.) A Naturalist's Rambles About Home. $12 \mathrm{mo}$. A N. Y.: D. Aprleton, 1884.

ABBOTT (CHAS. C.) Waste-Land Wanderings. 12mo. N. Y.: HARPER Bros., 1887.

ABBOTT (CHAS. C.) Days Out of Doors. 12mo. N. Y.: D. AppleTON \& Co., 1889.

ABBOTT (CHAS. C.) Outings at Odd Times. 16mo. N. Y.: D. AppleTON \& Co., 1890.

ABBOTT (CHAS. C.) Recent Rambles. First Edition. Illustrated. 12mo. Phila.: 1892.

ABBOTT (CHAS. C.) In Nature's Realm. 90 Drawings by Oliver Kemp. 8vo. Trenton, N. J.: 1900.

ABBOTT (CHAS. C.) Upland and Meadow. 12mo. N. Y.: N. D.

ABBOTT (SAMUEL). Ardenmohr Among the Hills. Illustrations. 8vo. London: 1876.

$\operatorname{ADAM}(W$.$) Gem of the Peak. Third Edition. 12mo. London: 1843$.

$\operatorname{ADAM}(W$.$) Dales, Scenery, Fishing Streams, and Mines of Derbyshire.$ Illustrated. 12mo. London: W. KeNT \& Co., 1861.

ADAMS (A. LEITH). Field and Forest Rambles. (Part III. Fishes). Illustrated. 8vo. London: H. S. King \& Co., 1873.

ADAMS (JOHN QUINCY). Duplicate Letters, the Fisheries and the Mississippi. Second Edition. 8vo. Louisville : 1823.

ADAMS (W. H. D.) Mysteries of the Ocean. New Edition, Revised. Illustrations. 8vo. London: 1870.

[ADAMS (WM. TAYLOR).] Sports and Pastimes for In-Doors and Out, with Additions by Oliver Optic. (pseud.) 16mo. Boston: G.W.CotTRELL, N. D.

ADVANTAGES (On the) and Utility of a Proposed New 'Treatise on the Art of Angling, etc. 12mo. N. P.: N. D.

AFLALO (F. G.) Sport in Europe. Illustrations. "4to. Lond.: Sandos \& Co., 1901.

AGASSIZ (ELIZABETH C.) and Alexander Agassiz. Seaside Studies in Natural History. 8vo." Boston : Trornor \& Fier.ds, 1865.

AGASSIZ (LOUIS). Histoire Naturelle des Poissons d'Eau Douce de L'Europe Centrale. Plates. Oblong 4to. Neuchatel: 1839. 
AGASSIZ (LOUIS). Histoire Naturelle des Poissons d'Eau Douce de L'Europe Centrale. Embryologie des Salmones par C. Vogt. 4to. Neuchatel : 1842.

AGASSIZ (LOUIS). Lake Superior: with Narrative of the Tour by J. E. Cabot. Illustrated. 8vo. Boston: 1850.

AGASSIZ, BAIRD and JORDAN. Six Species of North American Fresh-Water Fishes. Six Lithographs from Drawings by A. Sonrel. Explanation of Plates by D. S. Jordan. Folio. Washington: SmrrHsonian INstitution, 1889.

AGRIPPA (HENRY CORNELIUS). The Vanity of Arts and Sciences. [Chap. LXXVI., of Fishing.] Portrait. 12mo. London: J. C. For Samuel Speed, 1676.

AKERMAN (JOHN YONGE). Spring-Tide; or The Angler and His Friends. Portrait and Illustrations. 16mo. Lond.: R. Bentrex, 1850.

AKERMAN (JOHN Y.) Spring-Tide. Second Edition. 16mo. R. BENrLEY, 1852.

ALBIN (ELEAZAR). The History of Esculent Fish. Plates, (uncolored.) And An Essay on the Breeding of Fish, etc., by Roger North. 4to. London: Edward JeFFret, 1794.

ALBIN. NOR'TH (Hon. ROGER). A Treatise on Fish and Fish Ponds. 18 Colored plates by E. Albin. Folio. London: J. Goopwin, N. D.

ALDAM (W. H.) A Quaint Treatise on "Flees, and the Art a' Artyfichall Flee Making," by an Old Man. Two Chromo-Lithographic Facsimiles and Patterns of Flies, with Samples of Materials. 4to. London: J. B. $\mathrm{D}_{\Delta \mathrm{Y},}, 1876$.

ALDROVANDUS (VLYSSIS). De Piscibus Libri V. et de Cetis Liber I. á Ioanne Corneliouteruerio, etc. Folio. (Stamped pigskin, dated 1660). Francofurti : 1647.

ALEXANDER (COL. SIR JAS. EDWD.) Salmon-Fishing in Canada. Illustrated. 12mo. Lond.: Longman, 1860.

ALEXANDER (W., F. S. A. and L. S.) A Journey to Beresford Hall, the Seat of Charles Cotton, Esqre. Facsimile MS., etc. Portrait and Vignette. 4to. London: J. R. Sмгтн, 1841.

[ALFRED (H. J.)] $\Lambda$ Complete Guide to Spinning and Trolling. By "Otter." Illustrated. 16mo. London: 1855.

[ALFRED (H. J.)] A Complete Guide to Spinning and Trolling. By "Otter." Second Edition. Illustrated. London: 1863. 
Haska. Attiotory of the Wrougs of alaska. 80. Sart trancisco $18 \%$ 
American (The, Agricull urist Cycloperia of hatural Atiotory/: sllustrated. $18^{\circ}$ from tom. Agreculturist $n y$.

1887 
[ALFRED (H. J.)] The Modern Angler. By "Otter." Illustrated. 16mo. London: Alfred \& Son, 1864.

[ALFRED (H. J.)] The Modern Angler. By "Otter." Illustrated. Second Edition. 16mo. London: Alrred \& Son, 1866.

[ALFRED (H. J.)] The Modern Angler. By "Otter." New Edition. Illustraten. 16mo. London: (1876).

[ALFRED (H. J.)] A Complete Guide to Spinning and Trolling. By "Otter." New Edition. Illustrated. 16mo. London: N. D. (1878).

ALFRED (H. JERVIS). On the Science of "Pike Fishing." 8vo. London: Alfred \& Son, N. D. (1881)?

ALLEN (RICHA RD L.) Last Letters of. Photo-Portrait. 8vo. N. Y. : 1871.

ALLERTON (R. G.) Brook Trout Fishing. Colored Trout, Portrait, etc. $12 \mathrm{mo}$. New York : 1869.

AMERICAN FISH CULTURISTS' ASSOCIATION REPORTS. (First Report made in 1870.) 19 Reports, being Nos. 6, 7, 10, 11, 12, $13,14,15,17,19,20,22,23,24,25,26,27,28$ and 29 . 8vo. $1878-1900$.

* This Association was organized in 1870, and was called "The American Fisheries Society," afterwards changed to "The American Fish Cultural Association," and finally assumed the above title.

AMERICAN ANGLER. Edited by Wm. C. Harris. Vols. I.-XV. Folio. New York: 1881-1889.

AMERICAN GAME FISHES. By W. A. Perry ("Sillalicum"), A. A. Mosher and others. Colored Flies and other illustrations. 8vo. Chicago and New York: 1892.

AMERICAN TURF REGISTER AND SPORTING MAGAZINE. Vols. I.-IV.-Sept., 1830, to Aug., 1833. (Fish and Fishing, Tront Fishing, etc.) 8vo. Baltimore : 1830-1833.

AMERICAN TURF REGISTER AND SPORTING MAGAZINE. Edited by $\mathrm{Wm}$. T. Porter. Illustrated. (Trout Fishing on L. I., etc.) Vol. I. New Series. 8vo. N. Y.: 1839.

AMPHLETT (F. H.) The Lower and Mid Thames. Illustrations. 16mo. London (1894).

[ANDERDON (JOHN L.)] The River Dove. By J. L. A. $16 \mathrm{mo.}$ London: Wm. Pickering, 1847.

ANDERSON (REv. JOHN, D. D.) Sprigs of Heather. 12mo. Edin. and Perth: 1884.

ANDROSCOGGIN LAKES. Illustrated. (Information on Hunting and Fishing.) 16mo. Boston: 1888. 
ANGLER'S (THE) ALMANAC AND POCKET-BOOK FOR 1853. By a Practical Angler. Illustrated. 16mo. London: (1853).

ANGLER'S (THE) ALMANAC AND POCKET-BOOK FOR 1854. Illustrated. 16mo. London: (1854).

ANGLER'S (THE) ALMANAC AND POCKET-BOOK FOR 1855. Illustrated. 16mo. London: (1855).

ANGLER'S (THE) ASSISTANT. Vignette. 12mo. London: W. MAsoN, N. D.

ANGLER'S (THE) ASSISTANT. Being An Epitome of ye Whole Art of Angling. 4to, broadside. Sold by M. Sheepy, under the Royal Exchange in Cornhill. Pr. 6d. N. P., N. D.

ANGLER'S (THE) ASSISTANT, or the Complete Art of Angling. Frontispiece (part of which is colored) and Vignettes on cover and title. 12mo. York: C. Croshaw, N. D.

ANGLER'S (THE) COMPANION. Bailey's New Edition. Colored Frontispiece. 12mo. London: J. BaILEx, N. D.

ANGLER'S (THE) COMPANION. Illustrated. 16mo. London: J. Allen, N. D.

ANGLER'S COMPANION AND GUIDE (THE) to the White Horse Fisheries, etc. 24 mo. London: Cowie, N. D.

ANGLER'S (THE) GUIDE. By a Lover of the Art. Frontispiece of Fish. 24mo. London: Joseph Smith, 1828.

ANGLER'S (THE) GUIDE. With Every Necessary Information for Angling. Engravings. 24mo. London: R. Holmes, N. D.

ANGLER'S (THE) HANDBOOK. Two Colored Plates of Flies. New Edition. 32mo. London: Routledge, 1846.

ANGLER'S (THE) MAGAZINE. By a Lover of that Innocent and Healthful Diversion. 16mo. London: Printed For W. OWen, 1754. ANGLER'S (THE) MANUAL; with 12 plates designed and etched by S. Howitt. Oblong 24mo. Liverpool : 1808.

ANGLER'S (THE) NOTE-BOOK AND NATURALIST'S RECORD. Green Series Complete. Six woodcuts. Sq. 8vo. London: 1880.

ANGLER'S (THE) NOTE-BOOK AND NATURALIST'S RECORD. The Yellow Series Complete. Illustrated. Sq. 8vo. London: 1888. ANGLER'S (THE) POCKET-BOOK. Third Edition. 16mo. London : H. K. Catston, 1805.

ANGLER'S (THE) POCKET-BOOK. 12mo. Norwich: J. PAyne, N. D. 
Annual. The Row Bud. (4 Contributions on Fih Fishuig) 180 Appleton's Atand = Bcoll of Anericin traved. The hosthere

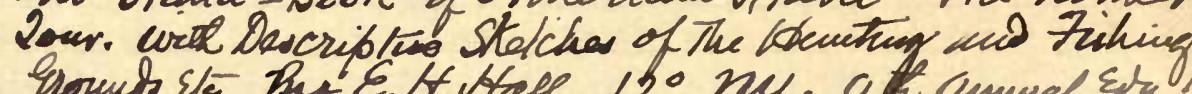

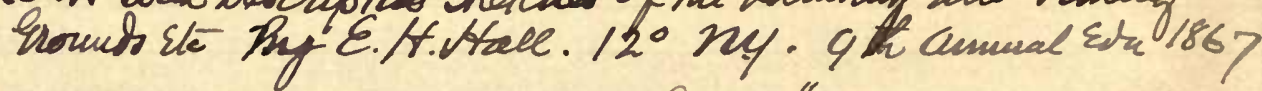
trmals of my Villegen Bo The aukior of "Belect Temale Biog-

Ashmead, Duffield, The Childs' Hustrated Book of hatural toriston. Fishes. The thale, Pitce Fly in tish, salmor shavk ullackere, swort tid tood. colored plate of Each fich 4; Phich S. Whimad 1868 
ANGLER'S (THE) POCKET COMPANION ; A Complete and Superior Treatise on the Art of Angling. Bailey's New Edition. 24mo. London: J. BAILEY, N. D.

ANGLER'S SPECIALTIES. Enterprise Manufacturing Co., Akron, O. Oblong 8vo. Akron: 1898.

ANGLING. Article from the 8th edition of the Encyclopædia Britannica, written by Jas. Wilson, with several plates of Fish. 4to. N. P., N.D. ANGLING. Illustrated Article on Angling. Taken from "Chambers's Information for the People." 4to. N. P., N. D.

ANGLING JOURNAL. 4 vols. fol. (Vols. III., IV., V., VI.), from March 31, 1883, to Dec. 25, 1886 . London.

ANGLING. The Out-of-Door Library. By Leroy M. Yale and others. Illustrated. 12mo. (New York): Chas. Scribner's Sons, 1896.

ARMISTEAD (J. J.) An Angler's Paradise. 8vo. Published by the Angler's Limited. [London]: 1895.

ARMISTEAD (J. J.) A Handy Guide to Fish Culture. Engravings. 12mo. Published by The Angler's Limited. Scarborough: 1897.

ARMSTRONG (CHAS.) The British Angler's Handbook. Illustrated. 32mo. London: N.D.

* The Author formerly with J. Cheek.

ARNOLD (AUGUSTUS C. L.) AND SAMUEL (EDWARD A.) The Living World. Animals, Birds, Fishes, etc. Illustrated. 2 vols., 4to. Boston: S. W ALKeR \& Co., 1868.

ART OF ANGLING. Bailey's New and Complete Edition. Colored Frontispiece. $16 \mathrm{mo}$. London: J. BaILEY, N. D.

ART (THE) OF ANGLING. Front. and Vig. 48mo. London: Hodgson de Co., 43 King St., Snow Hill, and 43 Holywell St., Strand, N. D.

ART (THE) OF ANGLING. Front. and Vig. 48mo. London : HodGson \& Co., 10 Newgate St., N. D.

ART (THE) OF HUNTING, TRAPPING AND FISHING. Illustrated. 16mo. N. Y.: Hurst \& Co., N. D.

ART (THE) OF PRESERVING HEALTH. First Edition. 8vo. London: A. Millar, 1744.

ARTEDI (PETRI). Ichthyologia Sive Opera-Omnia de Picibus Scilicet, etc. Edidit Carolus Linnæus. 12mo. Lugduni Batavorum: C. WISHorf, 1738.

ASIATIC SOCIETY OF JAPAN, Transactions of. Vol. III., part II.;

Vol. V., part I. Maps, etc. 8vo. Yokohama: 1884. 
ASHTON (JOHN). Curious Creatures in Zoology. 130 Illustrations. 8vo. N. Y.: CASSELL, N. D.

ASHWORTH (EDMUND AND THOMAS). A Treatise on the Propagation of Salmon, etc. Woodcut Title and a Plate. 12mo. Stockport: E. H. King, 1853.

ASHWORTH (THOS.) Salmon ('The) Fisheries of England, 1868. Colored Front. 16mo. London and Bath : N. D.

ATHLETIC SPORT FOR BOYS. 194 Woodouts (Angling). $16 \mathrm{mo}$. N. Y.: Dick \& Fitzaerald, N. D.

AUSTIN (HENRY). American Game and Fish Laws. 16mo. Boston : 1891.

AUSTIN (F. W. G.) Remarks on the Fisheries Bill, Addressed to the Hon. A. Campbell. 8vo. Quebec: 1865.

AVON. (pseud.) How I Became a.Sportsman. Illustrated. $12 \mathrm{mo.}$ London : 1882.

AXON (WM. E. A.) Field (The) Naturalist. Illustrated. Sq. 8vo. Manchester: 1883.

AYRES (WM. O.) Enumeration of the Fishes of Brooklaven, Long Island. 8vo. (Boston: 1842.)

* From Boston Journal of Natural History, pp. 255-302. 1843.

AYRTON (WILLIAM). Adventures (The) of a Salmon. Illustrated. 16mo. London: 1853.

D ADDELEY (JOHN). London (The) Angler's Book. 12mo. London : G. Parsonage, 1834.

BADHAM (Rev. C. DAVID). Prose Halieutics, or Ancient and Modern Fish Tattle. 12mo. London: 1854.

[BAGG (R. BOWERS) ]. Lochleven (The) Angler. By "An Ex-President of the Kinross-Shire Fishing Club." Front. and map. 16mo. Kinross: 1874.

BAGNALL (GEORGE). Piscatorial Rambles. 16mo. London: R. J. Kennett, 1865.

BAILEY (N.) All the Familiar Colloquies of Desiderius Erasmus, of Rotterdam. 12mo. London: J. DARBY, etc., 1725.

* With "Venatio on Fishing with a Worm," etc.

BAILEY (WM.) Angler's (The) Instructor. First Edition. 12mo. London and Nottingham : 1857.

BAILEY (WM.) Angler's (The) Instructor. Second Edition. $16 \mathrm{mo}$. Nottingham and London: (1866). 


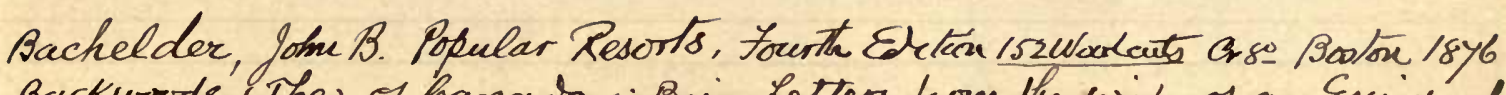
Backwords (The) of banada: Being Letten from the wife of an Enciegrawh officer. Heisi: $16^{\circ}$ Loudru: C.Mnight. 1836. 

BAILEY (WM.) Angler's (The) Instructor. Third Edition, Revised. 12mo. London and Nottingham: N. D. (1866).

BAILLIE-GROHMAN (WM. A.) Camps in the Rockies. Illustrated. 12mo. London: 1882.

BAILLIE-GROHMAN (WM. A.) Camps in the Rockies. Map. $12 \mathrm{mo}$. New York: 1882.

BAINBRIDGE (GEO. C.) Fly (The) Fisher's Guide. First Edition. With Colored Plate of a Trout, and 7 Plates of Colored Flies. 8vo. Livcrpool: Printed for the Author, 1816.

* Large Paper Copy.

BAINBRIDGE (GEO. C.) Fly (The) Fisher's Guide. Second Edition, with Additions. 8 Colored Plates. 8vo. Liverpool : 1828.

BAINBRIDGE (GEO. C.) Fly (The) Fisher's Guide. Colored Plates. Third Edition. 8vo. London and Liverpool: 1834.

BAINBRIDGE (GEO. COLE). Fly (The) Fisher's Guide. Colored Plates. Fourth Edition. 12mo. London: 1840.

BARBER (JOSEPH). Crumbs from the Round Table. 12mo. New York: Leypolit) \& HoLt, 1866.

BARKER (THOS.) The Art of Angling. 16mo. London: Printed by R. H., 1651.

* Burn's Reprint of the First Edition. Reprint of Second Edition (1657) also bound in with the above.

BARKER (THOMAS). The Art of Angling. Second Edition. $12 \mathrm{mo.}$ London: Printed in the year 1653.

BARKER'S DELIGHT: or, The Art of Angling. Second Edition. 16mo. London: Printed by J. G. For Riohard Marriot, 1657.

* Burn's Reprint.

BARKER'S DELIGHT: or, The Art of Angling. The Second Edition, Much Enlarged. By Thomas Barker. 12mo. London: J. G. MarRIOT, 1657.

* Four Copies, Reprinted for J. H. Burn, Maiden Lane, Covent Garden, 1820. This is one of the four straw-colored copies.

BARNARD (Rev. M. R.) Sport in Norway, and Where to Find It. Front. 12mo. London: 1864.

[BARNES (DAME JULYANS).] Literary Researches Into the Histøry of the Book of Saint Albans. By Joseph Haslewood. (150 copies printed). 4to. London: Reprinted by Harding \& Wright, 1810. [BARNES (DAME JULYANS).] An Older Form of The Treatyse of Fysshynge Wyth An Angle. Sq. 8vo. London: 1883.

* Only 200 Copies of this Edition, called Foolscap Quarto, printed. 
[BARNES (DAME JULYANS).] An Older Form of The Treatyse of Fysshynge Wyth An Angle. Preface and Glossary by Thos. Satchell. 8vo. London: 1883.

* Four Hundred Copies printed solely for presentation to friends.

[BARNES (DAME JULYANS).] The Treatyse of Fysshynge With an Angle. An American Edition, Edited by Geo. W. Van Siclen. $16 \mathrm{mo}$. New York : 1875.

[BARNES (DAME JULYANS).] A Treatyse of Fysshynge Wyth an Angle. Edited by "Piscator." 8vo. Edinburgh: Privately PRINTED, 1885.

* Large Paper of the "Bib-Curiosa" Series.

[BARNES (DAME JULYANS).] The Boke of St. Albans. Reproduced in Facsimile. 4to. London: E. Stock, 1899.

"BARRISTER AT LAW." The Laws of England Concerning the Game of Hunting, Hawking, Fishing and Fowling, etc. By A Barrister at Law. 16mo. In the Savoy: E. \& R. Nutr, 1727.

BARROWS (SAM'L J. AND ISABEL C:) The Shaybacks in Camp. Map. 16mo. Boston and New York: 1887.

BARRY (Rev. GEO., D.D.) History of the Orkney Islands. Map and Plates. 4to. Edinburgh: 1805.

* Fish on the Coast of Orkney, etc.

BARRY (W.) Moorland and Stream. Shooting and Trout Fishing. 12mo. London: 1871.

BARRY (WM.) Sporting Rambles and Holiday Papers. 16mo. London and New York: Routledge, N. D.

BARTLETT (A. E.) The Ludicrous Experiences of a Humorous Angler. By An Old Fisherman. Illustrated. Sq. 24mo. Kalamazoo, Mich.: (1884).

BASSETT (FLETCHER S.) Sea Phantoms. Revised Edition. Illustrated. 12mo. Chicago: 1892.

BATEMAN (REv. GREGORY C.) Fresh-Water Aquaria. Illustrated. 12mo. London : 1890.

BATES (FRANK A.) Stories of Lake, Field and Forest. Engravings. 12mo. South Braintree, Mass.: 1899.

BATHURST (Hon. and Rev. CHAS.) Notes on Nets. Plates. $16 \mathrm{mo.}$ London: JoHN VAN Voorst, N. D.

BAUDE (J. J.) L'Empoissonnement des Eaux Douces. 8vo. (Paris: 1861.)

*Taken from " Revue des Deux Monde." 


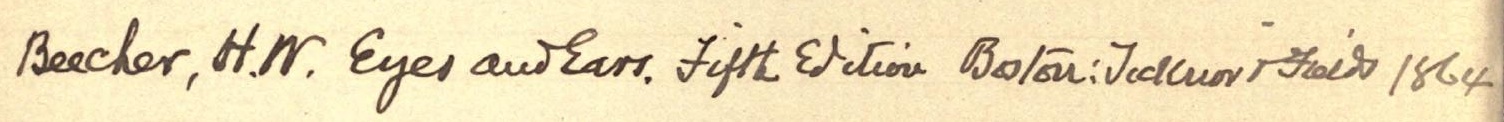


BAUDRILlaRT (M.) Traité Général des Eaux et Forêts, Chasses et Peches. Quatrieme Partie. Atlas of Plates. Fol. Paris: Arthus Bertrand, 1827.

BAUDRILLART. Dictionnaire de Pêches. Arec un Atlas Composé de 40 Planches. (Text only.) 4to. Paris: 1833.

BEARD (D. C.) American Boy's Handy Book. New Edition. $12 \mathrm{mo.}$ New York: 1899.

BEARD (D. C.) The Jack of All Trades. Illustrated. 12mo. New York: Scribners, 1900.

BEAUFOY (HENRY). Speech to the British Society for Extending the Fisheries, etc. 8vo. London: 1788.

BECKER (BERNARD H.) Holiday Haunts by Cliffside and Riverside. Front. $12 \mathrm{mo}$. London: 1884.

BEDDARD (F.E.) A Book of Whales. Forty Illustrations. $8 \mathrm{vo.}$ London: 1900.

BEECHER (HENRY WARD). Star Papers. First Edition. $12 \mathrm{mo.}$ New York: 1855.

BEECHER (HENRY WARD). Eyes and Ears. First Edition. $12 \mathrm{mo.}$ Boston : 1862.

BEECHER (HENRY WARD). Norwood. First Edition. 12mo. New York : 1868.

BEECHER (HENRY WARD). Norwood. Fortieth Edition. $12 \mathrm{mo.}$ New York: Scribner, 1868.

BEETON (S. O.) Books of Home Pets. The Aquarium, etc. Illustrated. 12mo. London: (1862.)

[BEEVER (JOHN).] Practical Fly-Fishing: Founded on Nature. By Arundo. (pseud.) 16mo. London: For the Aurhor, 1849.

BEEVER (JOHN). Practical Fly-Fishing. 12mo. London: 1893.

BEEVER (JOHN). Practical Fly-Fishing. A New Edition, with a Memoir of the Author. By W. G. Collingwood. 8vo. London: 1893.

*Fifty-six copies printed on Dutch handmade paper, No. 29.

BELLAMY (J. C.) The Housekeeper's Guide to the Fish-Market, and an Account of the Fishes and Fisheries. First Edition. $24 \mathrm{mo}$. London: Longmans, 1843.

BELON (PIERRE). La Nature and Diuersité des Poissons. Engravings. Oblong 32mo. A Paris: Chez Chas. Ettienne, 1555.

[(BELTON).] Angler (The) in Ireland. Tro Engraved Frontispieces after dravings by Saml. Lover. 2 vols. 12mo. London: 1834. 
[(BELTON).] Two Summers in Norway. 2 Maps. 2 vols. 12mo. London : 1840.

BENJAMIN (S. W. G.) Multitudinous (The) Seas. Illustrated. $16 \mathrm{mo.}$ N. Y.: Appleton, 1879.

BENNET (J. HENRY). Winter and Spring on the Shores of the Mediterranean. Fourth Edition. Illustrations and Maps. $12 \mathrm{mo.}$ New York: 1870.

BENNETT (J. W.) Rare and Curious Fishes of Ceylon. The Drawings in sepia before the coloring. 4to. London: 1851.

BENNETT (J. W.) A Selection of Rare and Curious Fishes of Ceylon. Colored Copy. 4to. London: For the Adthor, 1851.

BENTLEY (C. S.) Sense (The) of Pain in Fishes. 8vo. London: 1881.

BENTLEY (H. CUMBERLAND). The Legend of the Black Loch. Illustrated by Wycliffe T'aylor. ()blong 4to. London: Mressrs. Fores, N. D.

BENTLEY (H. CUMBERLAND). Poems. (With Legend of the Black Loch). 8vo. London: 1900.

BERTHELOT (SABIN). Etudes sur les Pêches Maritimes dans la Mediterranée et L'Ocean. 8vo. Paris: 1868.

BERTRAM (JAS. G.) Harvest (The) of the Sea. 50 illustrations. First Edition. 8vo. London: Murray, 1865.

BERTRAM (J. G.) Harrest of the Sea. 50 illustrations. 8ro. New York: Appleton, 1866.

BERTRAM (J. G.) Harrest of the Sea. Second Edition, with illustrations. 8vo. London: Murray, 1869.

BERTRAM (J. G.) Harvest of the Sea. Third Edition, with 50 illustrations. 12mo. London: Murray, 1873.

BERTRAM (J. G.) Harvest of the Sea. Fourth Edition. 12mo. London: Alex. Gardner, 1885.

BEST (THOMAS). A Concise Treatise on the Art of Angling. Second Edition, corrected and enlarged. Front. 16mo. London: C. Stalker, N. D.

BEST (THOS.) A Concise Treatise on the Art of Angling. Third Edition, corrected and improved. Front. 16mo. London: B. CROsBY, 1794.

BEST (THOS.) A Concise Treatise on the Art of Angling. Fourth Edition, corrected and improved. Front. 16mo. London: B. CвоsвY, 1798. 
Benselt (Geo.) Gatherings gets. Aataralish in Australia: Musi in colors. 80 Lous: G.VanVoosh 1860

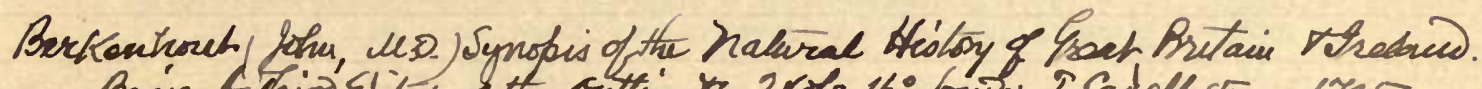

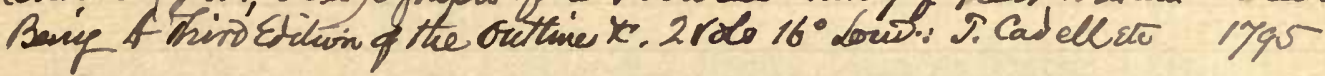



BEST (THOS.) A Concise Treatise on the Art of Angling. Fifth Edition, carefully revised. Front. 16mo. London: B. Crossr, 1802. BEST (THOS.) A Concise Treatise on the Art of Angling. Sixth Edition. 16mo. London: B. Crosby \& Co., 1804.

BEST (THOS.) A Concise Treatise on the Art of Angling. Seventh Edition. Front. 16mo. London: B. Crosby, 1807.

BEST (THOS.) A Concise Treatise on the Art of Angling. Eighth Edition. Front. 16mo. London: B. Crosbr, 1808.

BES'T (THOS.) A Concise Treatise on the Art of Angling. Ninth Edition. Front. 16mo. London: B. Crosby, 1810.

BEST (THOS.) Art (The) of Angling. Tenth Edition. Front. $16 \mathrm{mo.}$ London : B. \& R. Crosby, 1814.

BEST (THOS.) Art (The) of Angling. Eleventh Edition. Front. of Flies and Vignette on Title. 16mo. London: Baldwin, Cradock \& Jox, 1822.

BEST (THOS.) Art of Angling and Nobb's Complete Troller. Twelfth Edition. Revised by John Jackson. Front. and Vignette. $32 \mathrm{mo}$. London : 'Thos. Tega, 1838.

BEST (THOS.) Art of Angling and Nobb's Complete Troller. Vig. Thirteenth Edition. Revised by John Jackson. 32mo. London. Thos. Tega, 1846.

BETHUNE (GEO. W.) Oration Before the Literary Societies of Yale College, Aug. 19, 1845. 8vo. Phila.: Jonn C. Clark, 1845.

BEWICK. A Memoir of Thomas Bewick, Written by Himself. Wood engravings. 8ro. London: Lonamans, 1862.

BEWICK MEMENTO. With an Introduction by Robert Robinson. Illustrated. 4to. London: Field \& TUER, 1884.

BIGLAND (JOHN). A Natural History of Birds, Fismes, Reptiles and Insects. 12 colored plates. First Edrtion. 12mo. Phila.: JoHN GrIGG, 1828.

BIGLAND (JOHN). A Natural History of Birds, Fishes, Reptiles and Insects. 12 colored plates. 12mo. Phila.: JoHN GRIGG, 1832.

BIGLAND (JOHN). A Natural History of Birds, Fisues, Reptiles and Insects. New Edition. Woodcuts. 12mo. Phila.: Lippincotr, 1865. BISHOP (NATHANIEL H.) Voyage of the Paper Canoe. Front. 8vo. Boston: Lee \& Sirmpard, 1878.

BISHOP (W. H.) Fish and Men in the Maine Islands. Illustrated. 12mo. New York: Harpers, 1885. 
BLACKER (W.) Art of Angling, and Complete System of Fly-Making and Dyeing of Colors. Front. 24mo. London: Published by the A Uthor, March, 1842.

BLACKER (WILLIAM). Blacker's Art of Fly-Making, etc., Comprising Angling and Dyeing of Colors. Engravings of Salmon and Trout Flies, etc. Rewritten and Revised by Blacker Himself. $16 \mathrm{mo}$. London : 1855.

* First Edition in this shape.

BLACKER (WILLIAM). Art of Fly Making. Frontispiece (uncolored) and Colored Plates of Flies, etc. Third Edition. 16mo. London: 1855.

BLACKMORE (R. D.) Slain by the Doones. 16mo. New York: Dond, Mrad \& Co., 1897.

BLACKMORE (R. D.) Tales from the Telling-House. 16mo. London : Low, 1898.

BLACKMORE (R. D.) Crocker's Hole, Trout Fishing in Maine, etc. 12mo. N. P., N. D.

"BLACK PALMER." Scotch Loch Fishing. By "Black Palmer." 12mo. Edin. and London: Blaokwood, 1882.

BLACK'S GUIDE TO THE ENGLISH LAKES. Map, 4 Charts, and Views. 16mo. Edin.: A. \& C. Black, 1841.

BLACK'S GUIDE TO MOFFAT. With Railway Chart and Map. 16mo. Edin.: A. \& C. Brack, 1871.

[BLAGRAVE (JOS.)] The Epitome of the Art of Husbandry. By J. B., Gent. 16mo. London: Printed for Benjamin Billingsir, 1685.

BLAINE (DELABERE P.) An Encyclopædia of Rural Sports. 600 Engravings on Wood. First Edition. 2 vols., 8vo. London: 1840.

BLAINE (D. P.) Rural Sports. A New Edition Revised and Corrected. 600 Engravings. 8vo. London: 1852.

BLAKE (PROF. CARTER). Special Illustrated Guide to the International Fisheries Exhibition. 12mo. London: (1883).

BLAKEY (ROBT.) Angler's Complete Guide to the Rivers and Lakes of England. Front. 16mo. London: Whittaker \& Co., 1853.

BLAKEY (ROBT.) Angler's Complete Guide to the Rivers and Lakes of England. Front. 16mo. London: G. Philip \& Son, 1856.

BLAKEY (ROBT.) Angler's Complete Guide to the Rivers and Lakes of England. Second Edition Revised and Enlarged. Front. $16 \mathrm{mo}$. London: W. Kent \& Co., 1859. 

Blakey (R.) Angling; or, How to fnyle re Hew Editini Heustins. 180 aond. Roulletye, Tarue, Mouslegye 
BLAKEY (ROBT.) Angler's (The) Guide to the Rivers and Lochs of Scotland. Front. 16mo. London: D. Bogue, 1854.

BLAKEY (ROBT.) The Angler's Complete Guide to the Rivers and Lochs of Scotland. Second Edition. 16mo. London: 1859.

BLAKEY (ROBT.) Angler's (The) Song Book. 16mo. London: G. Cox, 1855.

BLAKEY (ROBT.) Angling; or, How to Angle, and Where to Go. A new Edition with Illustrations. 16mo. London and N. Y.: RootLEDGE, 1859.

BLAKEY (ROBT.) Angling: How to Angle, etc. New Edition with Illustrations. 16mo. London and N. Y.: RouTledes, 1865.

BLAKEY (ROBT.) Angling; How to Angle, etc. New Edition with Illustrations. $16 \mathrm{mo}$. London and N. Y.: N.D.

[BLAKEY (ROBT.)] Hints on Angling. By Palmer Hackle. 8vo. London: W. W. Robinson, 1846.

BLAKEY (ROBT.) Historical Sketches of the Angling Literature of all Nations. 16mo. London: J. R. Sмтн, 1856.

BLAKEY (ROBT.) Old Faces in New Masks. First Edition. Frontispiece and Engraved Title by G. Cruilishank. 12mo. London:W. KENT \& Co., 1859.

BLANCHARD (EMILE). Les Poissons Des Eaux Douces de la France. Avec 52 Planches Hors Text et 115 figures. 4to. Paris : 1880.

BLANCHERE (H. DE LA). Nouvean Dictionnaire Général des Pêches. Preface par Aug. Dumeril. Colored and other illustrations. 4to. Paris : 1868.

BLANCHERE (H. DE LA). La Pêche en eau Douce Contenant Tous les Principes de la Pêche a la Ligne, etc. Illustrated. $12 \mathrm{mo}$. Paris: N. D.

BLIGHT (J. T.) A Week at The Land's End. Illustrated. $16 \mathrm{mo}$. London: Lovgmans, 1861.

BLISS (RICHARD, JR.) On the Osteology of the Anterior Vertebræ in $\rightarrow$ Doras Niger, with a Comparison of the Structure of the Dorsal Fin in Doras and Balistes. 8vo. N. P., N. D.

BLOCH (MARC ELIESER). Ichthyologie ou Histoire Naturelle des Poissons. En Six Parties. Avec 216 Planches. 6 vols. 8vo. (2 vols. of Plates.) Berlin: L'Auteur, 1796.

BLOCH. Histoire Naturelle des Poissons. Avec les figures dessinées d'Appres Nature. 10 vols. 24mo. Paris: Chez Derentille. (An ix.) 1809. 
BOARDMAN (SAM'L L.) and ATKINS (CHAS. G.) The Menbaden and Herring Fisheries of Maine. 8vo. N. P., N. P.

BOAZ (H.) Angler's (The) Progress. A Poem. 12 cuts. 16mo. London : Printed for J. H. Burn, 1820.

* Burn's Reprint.

BOAZ (H.) Angler's (The) Progress. A Poem. 12 Woodcuts. Second Edition on Large PAPER. 12mo. London : J. H. BurN, 1820.

BOCCIUS (GOTTLIEB). A Treatise on the Management of FreshWater Fish. Cut of Spiegel or Mirror Carp on Title. 8vo. London: J. VAN Voorst, 1841.

BOCCIUS (GOTTLIEB). Fish in Rivers and Streams. 8vo. London: J. VAN VoORST, 1848.

BOLLES (FRANK). Land of the lingering Snow. 16mo. Boston and New York: 1891.

BOLLES (FRANK). At the North of Bearcamp Water. 16mo. Boston and New York : 1893.

BONNATERRE (L'ABBE). Ichthyologie. Text and 102 Plates in 1 vol. 4to. Paris : Chez Panckodcke, 1788.

BONNET (CHARLES). Histoire Naturelle et de Philosophie. Portrait and Plates. 4to. Neuchatel: S. F AUCHE, $_{1779 .}$

BONNET (CHAS.) Histoire Naturelle et de Philosophie. 2 vols. 4 to. Neuchatel: Samuel Fadohe, 1781.

- The Volume only containing his Notes on Fish.

BOOSEY (THOS.) Piscatorial Reminiscences and Gleanings. By An Old Angler and Bibliopolist. Front. 16mo. London: W. PickerING, 1835.

BOOSEY (THOS.) Anecdotes of Fish and Fishing. 8vo. London and Glasgow: 1887 .

BORDER (The) Angler. Map. Second Edition. 16mo. Edin. and London: 1858.

BORDER (The) Angler. Shilling Edition. 16mo. Edin.: J. Menzues, N. D.

BOSTON FISH BUREAU. Annual Reports for the Years 1885, 1887, 1893, 1894, 1895, 1898, 1899 and 1900. 8 vols. 12mo. Boston.

BOSTON AND MAINE RAILROAD. Lakes and Streams. Illustrated. Square 8ro. Boston: Passenger Dept., 1896.

BOSTON AND MAINE RAILROAD. Fishing and Hunting. Illustrated. Sq. 8vo. Boston: PAssenger Dept., 1897. 


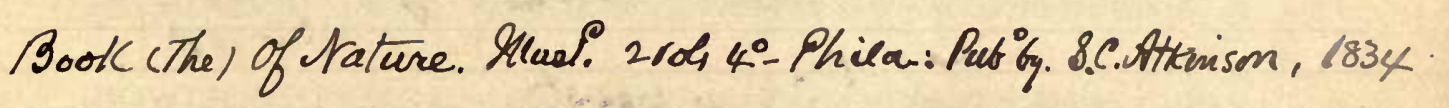

Borne. (Ulase Von Dem). Sllustarites Aandbuch der Angelfischerei.195 Hustüs. 12: Bertin 1845 


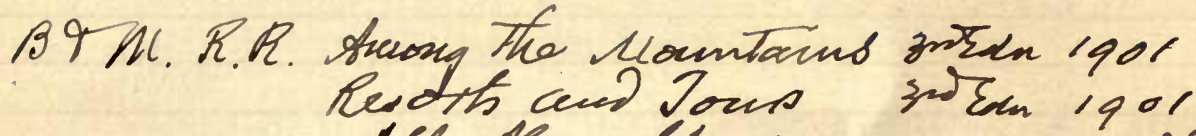
Lakes aubs Shove 1901 Bishing Hofuenting iq00 
BOSTON AND MAINE RAILROAD. Lake Sunapee. Illustrated. Sq. 8vo. Boston : Pagsenger Dept., 1897.

BOUCHON-BRANDELY (M.) Rapport au Ministre L'Instruction Publique sur L'Etat de la Pisciculture en France et dans les Pays Voisins. 8vo. Paris: 1873.

* Three pamphlets by same author in this Volume.

BOUSSUETI (FRANCISCI). Svrregiani-Doctor is Medici, de Natura Aguatilium Carmen. Quam de Piscibos Marinis Scripsit Historiam, ETC. Fine old engravings of Fish, etc. Sq. 8ro. LugdunI: Aprd Matrhiam Bonhome, 1558.

BOWDEN (REv. J.) The Naturalist in Norway. With Some Account of the Principa? Salmon Rivers. Illustrated. 12mo. London: L. REEVE \& Co., 1869.

BOWLKER (RICHARD). The Art of Angling. Improved in all its Parts. Especially Fly-Fishing. First Edition. 21mo. Worcester: Printed by M. Olivers, in Higi Street, N. D. [1758 ?]

BOWLKER (RICHARD). The Art of Angling. 24mo. Worcester : Printed by M. Olivers, in Hrah Street, N. D. [1758?]

* With four more pages than the above described copy.

BOWLKER (CHAS.) Art of Angling. Third Edition. Frontispiece mounted. 16mo. Birmingham: Printed by and for Swinney \& EvetTs. N. D.

BOWLKER (CHAS.) Art of Angling. Front. Fourth Edition. $16 \mathrm{mo}$. Birmingham and London : 1786.

BOWLKER (CHAS.) Art of Angling. Frontispiece. Fifth Edition. 16mo. Birmingham and London: M. Swinnex, 1788.

BOWLKER (CHAS.) Art of Angling. Frontispiece. Sixth Edition. 16mo. Birmingham and London: Swinney \& W ALKER, 1792.

BOWLKER (CHAS.) Art of Angling. Frontispiece (mounted). A New Edition. 16mo. Birmingham: Swinney \& Hawkins, N. D.

BOWLKER (CHAS.) Art of Angling. Front. A New Edition. (Seventh). 16mo. Ludlow: H. Prooter, 1806.

BOWLKER (CHAS.) Art of Angling. Front. A New Edition. (Eighth). 24mo. Ludlow: H. Procter, 1814.

BOWLKER (CHAS.) Art of Angling. Front. of Colored Flies. Ninth Edition. 16mo. Ludlow : Procter \& Jones, 1826.

BOWLKER (CHAS.) Art of Angling. Front. of Colored Flies. Tenth Edition. 16mo. Ludlow: Procter \& Jones, 1829. 
BOWLKER (CHAS.) Art of Angling. Front. Flies. Eleventh Edition. 16mo. Ludlow : R. Jones, 1833.

BOWLKER (CHAS.) Art of Angling. Front. of Flies. Twelfth Edition. 16mo. Ludlow: R. Jones, 1839.

BOWLKER (CHAS.) Art of Angling. Front. of Flies. A New Edition Revised. 16mo. Ludlow: R. Jones, 1854.

BOYS' OWN BOOK. First American Edition. Illustrated. Sq. 24 mo. Boston: Munroe \& Fraxcis, 1829.

BOYS' OWN BOOK, Extended. Illustrated. Sq. 24mo. Boston: Munroe \& Francis, 1851.

BOYS' OWN BOOK. Illustrated. Sq. 16mo. Louisville : Morton \& Griswold, 1854.

BOY'S OWN JOLLY ANGLING BOOK. Illustrated. 16mo. London: N. P., N. D.

BOY. EVERY BOY'S BOOK. Illustrated. A New Edition (Second ?) 12mo. Londou and New York: Rovtledge, 1862.

BOYS' HANDY BOOK OF SPORTS, Pastimee, Games and Amusements. Illustrated. 12mo. London: WARD Lockr \& Co. (1863 ?) BOYS' 'TREASURY OF SPORTS, Pastimes and Recreations. Nearly 400 Engravings. Third American Edition. 16mo. Boston: J. P. HiLl, 1848.

BOYCE (W. D.) A Strike. Portrait and Illustrations. Sq. 8vo. Chicago : 1894 .

BOYLE (Hon. R.) Occasional Reflections Upon Several Subjects. $16 \mathrm{mo}$. Londoll: Printed by W. Wilson for Henry Herrinaman, 1665.

BOYLE (Hon. R.) Occasional Reflections Upon Several Subjects. Portrait of the Author Eng. by Vander Gucht. Second Edition. $16 \mathrm{mo.}$ London: H. Herringman, 1669.

* Bound in at end "A Meditation Upon a Broomstick." London: Printed for E. Curll, 1710. Attributed to Dean Swift.

BRABAZON (WALLOP). Deep Sea and Coast Fisheries of Ireland. Illustrated by W. Cooper. First Edition. 8vo. Dublin: 1848.

BRADFORD (CHAS. BARKER). The Brook Trout. Illustrated. 16mo. New York (1900).

BRADLEY (TOM). Yorkshire Rivers. No. 1. The Wharf. Bird's-Eye View of the River. Second Edition. 12mo. Leeds : 1890.

BRADLEY (TOM). Torkshire Rivers. No. 2. The Nidd. Bird's-Eye View of the River and Roads Adjoining. 12mo. Leeds: 1890. 


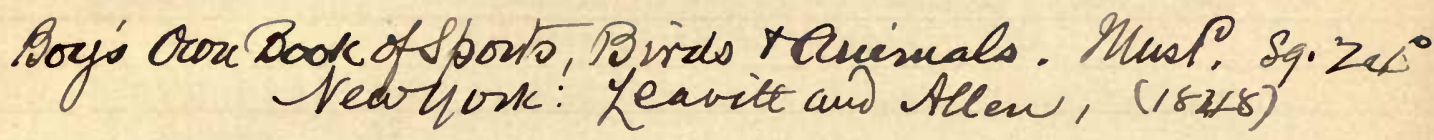

Boyle, Hou. R. Oecasional Reflections Whou Several Subjecto. $16^{\circ}$ Loudow: [Reprinh] Oxford. Hex. Tmbrose Classon, 1848. 

BRADLEY (TOM). Yorkshire Rivers. No. 3. The Ure. View of Roads and River Adjoining. 12mo. Leeds: 1890.

BRAITHWAITE (GEO. FOSTER). Salmonidæ of Westermorland. Frontispiece. 12mo. London and Kendal: 1884.

BREVOORT (JAS. CARSON). Notes on Some Figures of Japanese Fish. Colored Plates. 4to. Washington: 1856.

BRITISH FISHES. A Familiar History of. Illustrated. 16mo. London: Society for Promoting Xian. Knowledge. N. D.

BRITISH FISH AND FISHERIES. 24mo. London : Religrous Traot SocIETY. N. D.

BRITISH FISHERIES DIRECTORY 1883-4. 16mo. London: 1883.

BRITISH MUSEUM. List of the Specimens of Fish in the Collection of the British Museum. 16mo. London: 1851.

BROCCHI (P.) Traite de Zoologie Agricole Compenant des Eléménts de Pisciculture, etc. 603 Figures in. Text. 8vo. Paris : 1886.

BROCCHI (Dr.) La Pisciculture dans les Eaux Donces. Illustrated. 8vo. Paris: N. D.

BROMLEY-DAVENPORT (W.) Sport, Fox-Hunting, Salmon-Fishine, etc. Illustrated. First Edition. Sq. 8vo. London: Chapman \& HALL, 1885.

BROMLEY-DAVENPORT (W.) Sport. Illustrated. New Edition. 8vo. London : 1886.

BROMLEY-DAVENPORT (W.) Sport. Illustrated. New Edition. 12mo. London : 1888.

BROOKES (R.) A New and Accurate System of Natural History. Illustrated. First Edition. (Vol. III. is on Fishes.) 6 vols., 16mo. London: Printed for J. Newbeky, 1763.

BROOKES (RICHARD). Art of Angling. Illustrated with 133 Cuts. First Edition. 16mo. London: JoHN W

BROOKES (RICHARD). Art of Angling. 139 Cuts. Second Edition. 16mo. London: J. WATts, 1743.

BROOKES (R.) Art of Angling now Improved with Additions and Formed into a Dictionary. 135 Cuts. First Edition in this shape. 16mo. London: T. Lowndes, 1776.

BROOKES (R.) Art of Angling. 135 Cuts. Third Edition, with great improvements. 16mo. London: T. Lowndes, 1770.

BROOKES (R.) Art of Angling. 135 Cuts. Fourth Edition. $16 \mathrm{mo}$. London: T. Lowndes, 1774. 
BROOKES (R.) Art of Angling. 135 Cuts. Fifth Edition. 16mo. London: T. Lowndes, 1781.

BROOKES (R.) Art of Angling. 135 Cuts. Sixth Edition. $16 \mathrm{mo.}$ London: W. Lowndes, 1785.

BROOKES (R.) Art of Angling. 135 Cuts. A New Edition. $16 \mathrm{mo.}$ London: W. Lowndes, 1793.

BROOKES (R.) Art of Angling. 135 Cuts. A New Edition. $16 \mathrm{mo}$. London: W. Lowndes, 1799.

BROOKES (R.) Art of Angling. 135 Cuts. A New Edition, Corrected. 16mo. London: W. Lowndes, 1801.

BROWN (ABBIE FARWELL). The Book of Saints and Friendly Beasts. Illustrated. 12mo. Boston and New York: 1900.

[BROWN (JOHN J.)] The American Angler's Guide. Engravings. By An American Angler. First Edition. 24mo. New York: BurGess, Stringer \& Co., 1845.

[BROWN (JOHN J.)] American Angler's Guide. Engravings. By An American Angler. Second Edition. 24mo. New York: BuraEss, Stringer \& Co., $1 \varepsilon 46$.

[BROWN (J. J.)] American Angler's Guide. Third Edition. Illustrated. 12mo. New York: 1849.

[BROWN (J. J.)] American Angler's Guide. Illustrated. Fourth Edition. $16 \mathrm{mo}$. N. Y., 1849.

[BROWN (J. J.)] American Angler's Guide. Illustrated. Fourth Edition Revised, with a Second PART. 20 Lngravings of Angle Fish and Illustrations on the Margins of the Leaves. 12mo. New York: 1850.

[BROWN (J. J.)] American Angler's Guide. Fourth Edition. 20 Engravings of Angle Fish, etc. 12mo. New York: D. Appleton \& Co., 1857.

BROWN (J. J.) American Angler's Guide. Illustrated. Fifth Edition, with the addition of a third part. 25 Engravings of the Principal Angle Fish. 8vo. New York: 1876.

The first Edition, with the name on Title as Author.

BROWN (J. J.) Angler's Almanac for 1848. Illustrated. 8vo. New York: 1848.

BROWN (J. J.) Angler's Almanac for 1849. Illustrated. 8vo. New York: 1849.

BROWN (J. MORAY). Stray Sport. Illustrated. 2 vols. $12 \mathrm{mo.}$ Edin. and London : 1893. 
Brougham, Hany, Lord. Dialogues on hrstuich $24^{\circ}$ Phila.
E. Ferrett tlo

E. jerrett tlo $18 \& 5$ 


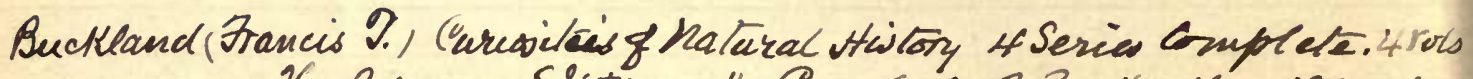
He Popular Elition. Hinil. 18-Sond. R/Bentley Hon 1982-3 
BROWN (THOS., Kr.) Certain Miscellany Tracts. 12mo. London : Chas. Mearne, 1684.

BROWN (WM.) Natural History of the Salmon. Illustrated. $16 \mathrm{mo.}$ Glasgow and London: 1862.

BROWNE (J. ROSS). Etchings of a Whaling Cruise. Engravings. 8vo. New York: 1846.

BROWNE (MOSES). Piscatory Eclogues. Frrst Edirion. Front. from the $3 d$ Edition inserted, the first to have one. 12mo. London: Printed by C. Ackers, 1729.

BROWNE (MOSES). Poems on Several Subjects. Frontispiece Engraved by J. Basire after H. Gravelot. 12mo. London: EDward CAvE, 1739.

BROWNE (MOSES). Angling Sports in Nine Piscatory Eclogues. Front. Third Edition. 16mo. London: Printed for Edward and Chas. Dilly, 1773.

BUCHAN (JOHN). Musa Piscatrix. Illustrated. 12mo. London : JoHN LANe, 1896.

BUCHANAN (REv. JOHN LANNE). A General View of the Fishery of Great Britain. 8vo. London: Printed for Tho. KAY, 1794.

BUCHANAN (ROBERT). The Land of Lorne. Illustrated. 2 vols. 12mo. London: 1871.

BUCKLAND (FRANCIS T.) Curiosities of Natural History. Front. First American Edition, from the Fourth London Edition. $12 \mathrm{mo.}$ New York: 1859.

BUCKLAND (FRANCIS T.) Curiosities of Natural History. First Series. Front. Tenth Edition. 16mo. London: Bentley, 1838.

BUCKLAND (FRANCIS T.) Curiosities of Natural History. Second Series. Front. 12mo. New York: 1860.

BUCKLAND (FRANCIS T.) Curiosities of Natural History. Second Series. Front. Sixth Edition. 16mo. London: 1867.

BUCKLAND (FRANCIS T.) Curiosities of Natural History. Illustrated. Third Series. Second Edition. 16mo. London: Bentuer, 1868.

BUCKLAND (FRANK T.) Fish Hatching. 12mo. London : 1863.

BUCKLAND (FRANK). Manual of Salmon and Trout Hatching. $12 \mathrm{mo}$. London: 1864.

BUCKLAND (FRANK). Log-Book of a Fisherman and Zoologist. Illustrated. First Edition. 12mo. London: 1875. 
BUCKLAND (FRANK). Log-Book of a Fisherman and Zoologist. Illustrated. Sixth Thousand. 12mo. London : 1891.

BUCKLAND (FRANK). Natural History of British Fishes. Illustrated. 12mo. London: (1880).

BUCKLAND. Life of Frank Buckland, by his Brother-in-Law Geo. C. Bompas. Portrait. Sixth Edition. 8vo. London: Smitn, Elder \& Co., 1885.

BUCKLAND (FRANK). Familiar History of British Fishes. Illustrated. 12mo. London: J. Truscotт \& Son, N. D.

BUCKLEY (ARABELLA B.) The Winners in Life's Race, or the Great Backboned Family. Illustrated. 12mu. New York: 1893.

BUFFON (LECLERC DE). Histoire Naturelle, Général et Particuliére des Poissons. Edited by C. S. Sonnini. Portrait and a series of finely colored plates. 14 vols. 12mo. Paris: F. Dufart, An. XI.XII., (1811-1812).

BUIST (ROBERT). The Stormonttield Piscicultural Experiments, 18531866. Illustrated. 16mo. Edin.: 1866.

BULGER (GEO. E.) Leaves from the Records of St. Hubert's Club. 8vo. London: L. Booth, 1864.

BULLEN (FRANK T.) The Cruise of the Cachalot. Illustrated. 12mo. New York: 1899.

BULLETIN of The U. S. Fish Commission, 1881-1899. 18 vols. 8vo and 4to. Washington: 1881-99.

BURGESS (J. T.) Angling: A Practical Guide to Bottom Fishing, \&c. Illustrated. 16mo. London: W ${ }_{\Delta \mathrm{RNE}},(1867)$.

BURGESS (J. T.) Angling and How to Angle. Revised and brought down to date by R. B. Marston. Portrait and Illustrations. $12 \mathrm{mo.}$ London: WARNE, 1895.

BURGESS (J. T.) Angling and How to Angle. Revised by R. B. Marston. 70 diagrams and illustrations. 12mo. London: W

BURKE (ULICK J.) The Boy's Walton. Illustrated. 16ıno. London: WARD \& Co., 1878.

BURNAND (F. C.) Round About My Garden; the Incomplete Angler, \&c. 16mo. London: Bradbery, Agnew \& Co., 1876.

BURNAND (F. C.) The Incomplete Angler. After Master Izaak Walton. Illustrated. 8vo. London: Bradbury, Agnew \& Co., 1887. BURROUGHS (JOHN). Locusts and Wild Honey. First Edition. 16mo. Boston: 1879. 

California Repr bowns Fiberies for yearr 1878-1879

Northern (The) Lakes of Canada Mapo thlun his. Edited by Burlew

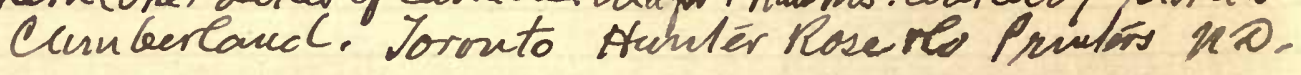


BURROUGHS (JOHN). Writings. Riverside Edition. Illustrations. 5 vols. 12mo. Boston and New York : 1895.

BURTON (Gens. E. F.) Trouting in Norway. Illustrated. $12 \mathrm{mo}$. Carlisle and London: 1897.

BURTON (RICHARD F.) The Lake Regions of Central Africa. Maps and Illustrations. 8vo. New York: Harpers, 1860.

BUSHNAN (J. S., M.D.) Natural History of Fishes. 33 colored plates. 16mo. Edin.: Lizars, 1840.

* Jardine's Naturalist's Library.

BUTLER (BENJ. F.) Address to Protect American Fisheries Against British Aggression. 8vo. Lowell : 1870.

CABINET (THE) OF NATURAL HISTORY AND AMERICAN RURAL SPORTS. Colored plates. 2 vols. and Four Parts (all published) bound in 2 vols. 4to. Phila.: Publisied bx J. \& T. DodGHTY, 1830-1834.

CADMAN (HENRY). Harry Druidale, Fisherman from Manxland to England. Illustrated. 8vo. London: 1898.

CALIFORNIA. Report (Sixth) of the Commissioners of Fisheries. S. of California, year 1880. 8vo. Sacramento: 1881.

CALL (RICHD. E.) Ichthyologia Ohiensis, or Natural History of the Fishes Inhabiting the River Ohio and its Tributary Streams. By C. S. Rafinesque. Portrait. 8vo. Cleveland: 1899.

* Reprint of the Edition of 1820 .

CALL (RICHD. E.) The Life and Writings of Rafinesque. Author's Edition. Portraits and facsimiles. Folio. Louisville: J. P. MorToN \& Co., 1895.

CAMPBELL (LADY COLIN). A Book of the Running Book. $16 \mathrm{mo.}$ London : 1886.

CAMPBELL (LADY COLIN). A Book of the Running Book. $16 \mathrm{mo}$. New York: O. Jodd Co., 1886.

CAMPBELL (LIIUT.-Cor. JAMES). Excursions, Adventures and FieldSports in Ceylon. Maps, colored plates, etc. 2 vols. 8vo. London: T. \& W, Boone, 1843.

CANADIAN PACIFIC RAILWAY. Fishing Resorts Along The. No. IV. Sq. 16mo. Montreal: 1887.

CANADIAN PACIFIC RAILWAY. Fishing and Shooting. Illustrated. Tenth Edition. 8ro. Montreal: 1898. 
CANADIAN PACIFIC RAILWAY. Fishing and Shooting. Illustrated. Fourth Edition. 8vo. Montreal : June, 1900.

CAPEL (CHAS. C.) Trout Culture. First Edition. 16mo. London: HARDWICKE \& Boget, 1877.

CAPEL (CHAS. C.) Trout Culture. Illustrated. Second Edition. 12mo. London and Brighton : 1885.

CAPPER (JOHN). Old Ceylon. Illustrations by Ceylon Artists. 8vo. London and Aberdeen : 1878.

CARBONNIER (PIERRE). Guide Pratique des Pisciculture. Vignette. 16mo. Paris: 1864 .

CARTER (ROBT.) A Summer Cruise on the Coast of New England. 12mo. Boston: 1864.

CARROLL (W.) Angler's (The) Vade Mecum, Containing a Descriptive Account of Water Flies. 12 Colored Plates. First Edition. $12 \mathrm{mo}$. Edin.: A. Constable \& Co., 1818.

CARPENTER (WM.) The Angler's Assistant. Illustrated. First Edition. 16mo. London: David Bogue, 1848.

CARPENTER (WM.) The Angler's Assistant. Front. of Colored Flies and other illustrations. Second Edition. 16mo. London: G. RoutLEDGE \& Co., 1852.

CARPENTIER (JULES). La Pêche Raisonnée et Perfectionnée du Pêcheur Fabricateur Toutes Lignes, etc. 92 engravings. $12 \mathrm{mo}$. Paris : 1879.

[CARTWRIGHT (REV. W.)] Rambles and Recollections of a FlyFisher. Mlustrated. By "Clericus." First Edition. 12mo. London : 1854.

[CARTWRIGHT (REV. W.)] Facts and Fancies of Salmon Fishing. With Original Illustrations. By "Clericus." 12mo. London: CasSELL, 1874.

CARUS (VICTOR). Histoire de la Zoologie Depuis L'Antiquité Jusqu' au XIX Siecle. 8vo. Paris : 1880.

CARVER(JONATHAN). Three Years' Travel Throughout the Interior Parts of North America. 16mo. Walpole, N. H.: Isaian Thomas \& Co., 1813.

CATALOGUES. A Bibliographical Catalogue of English Writers on Angling and Ichthyology. 12mo. London: Joun R. Sмrтн, 1856.

CATALOGUES. ALEXANDER (L. D.) Large and Valuable Library. Angling portion, pp. 31-99. Field Sports, etc., pp. 209-254. 8vo. New York: Bangs \& Co., 1895. 


CATALOGUES. AMERICAN AND MISCELLANEOUS BOOKS. Angling, pp. 20-24. 8vo. Boston: Chas. F. Libbie \& Co., 1899.

CATAlogues. BAILLIÈRE \& FILS. Poissons-Reptiles, etc. 8 vo. Paris : 1893.

CATALOGUES. BARTLETT (JOHN). Books on Angling. Including Ichthyology, Pisciculture, Fisheries and Fishing Laws. Sq. 8vo. Cambridge : 1882 .

* The Supplement is included. 100 of each printed.

CATALOGUES. THE BARTLETT COLLECTION. A List of Books on Angling, Fishes, and Fish Culture. In Harvard College Library. By Louise Rankin Albee. 8vo. Cambridge, Mass.: 1896.

CATALOGUES. BENJAMIN (W. E.) Catalogue of Angling and Sporting Books. N. Y.: 1888.

CATALOGUES. BIBLIOTHECA ICHTHYOLOGIA ET PISCATORIA. Catalogus. D. Mulder Bosgoed. 8vo. Haarlem: 1874. CATALOGUES. BIBLIOTHECA PISCATORIA. Books upon Angling. $16 \mathrm{mo}$. London: W. Pickering, 1836.

CATALOGUES. CLARKE \& CO. (ROBT.) Angling, Hunting, Shooting and Kindred Subjects. 8vo. Cincinnati, O.: 1888.

CATALOGUES. COTTON (REV.H.S.) Very Interesting and Singularly Curious Collection of Books on Angling. 8vo. London: S. Leigh Sothebx, 1838.

CATALOGUES. DODD, MEAD \& CO. (No. 9.) A Collection of Books Principally on Angling and Sporting. 8vo. New York: N. D. CATALOGUES. EXHIBITION OF WALTONIANA. At the Rowfant Club. (Finding List.) 12mo. Cleveland, Oct. 26, 27, 28, 1896. CATALOGUES. EYTON (T. C.) Fishing Literature. 12mo. Wellington, Salop.: 1871.

CATALOGUES. FISHING BOOKS. Drawings of Field Sports, etc. 8vo. London: Mr. Sothebr, 1828.

CATALOGUES. GOSDEN (T.) Engravings and Books on Angling and Field Sports. 16mo. London: 1825.

CATALOGUES. HASTIE (PETER) AND TRACY (E. H.) Library of. Angling, Lots 6268-6309. 4to. New York : Leavitt, 1877.

CATALOGUES. HAWORTH (RICHARD). Very Curious Collection of Works on Archery, Hunting and Fishing. 8vo. London: Mr. SoTHEBY, 1826.

CATALOGUES. HAYES (FRANCIS B.) Library. Angling Books, pp. 173-185. 8vo. New York: Bangs \& Co., 1898. 
CATALOGUES. HIGGS (WM. S.) Collection of Works on Angling. 8vo. London: Mr. Soтнкву \& Son, 1830.

CATAlOGUES. HOLLINGS (FRANK). Books on Sports and Pastimes. Illustrated cover. No. 17. Sq. 32mo. London: Holborn, W. C., N. D.

CATALOGUES. JONES (JAS.) Old Angling Books. 32ıno, paper. London: E. (No. 2. 1883.)

CATALOGUES. LEGGAT BROS. Angling, Boat Building, Ornithology, Natural History and Sporting. 8vo. New York: N. D.

CATALOGUES. LOCKWOOD \& COOMBES. John E. MeEwan's Collection Angling, Shooting and Field Sports. No. 7. 12mo. June, 1888. New York.

CATALOGUES. [LOWERY (JOHN A.)] Library of A Well-Known New York Collector. Angling, ete. 8vo. New York: BaNas \& Co., 1888.

CATALOGUES. LUYSTER (A. L.) A Special Catalogue of Books on Angling, Shooting, Field Sports, Natural History, etc. 12mo. New York : 1885.

CATAlogues. MARSH (J. C.) Books on Angling. 12mo. London : N. D., (1898.)

CATALOGUES. [MARSTON (R. B.)] A List of Books Relating to Fish, Fishing and Fisheries, to Supplement the Bibliotheca Piscatoria published in 1883. Interleaved. 8vo. London: SAMPson Low, 1901. CATALOGUES. MATHER (FRED.) Fish and Fisheries, etc. 8vo. New York: Bangs \& Co., 1900.

CATALOGUES. MAURICE \& CO. (A.) A Choice Collection of Books on Angling. Principally from the Library of E. F. Snow. 8vo. London: N. D.

CATALOGUES. MAURICE \& CO. (A.) Rare and Curious Sporting Books. 8vo. London: N. D.

CATALOGUES. MILLER (HENRY). Choice Collection of Books on Angling, Hunting, Natural History, etc. 8vo. New York: N. D.

CATALOGUES. MILLER (WM.) Angling, Sporting, etc. No. 11. Kingsland, N.: 1880.

CATALOGUES. PICKERING \& CHATTO. The Book-Lover's Leaflet. (About 400 rare Angling Books.) 12mo. London: 1893.

CATALOGUES. PICKERING \& CHATTO. Old and Rare Books. (Angling and Sporting.) 12mo. London: 1894. 


CATALOGUES. PICKERING \& CHATTO. Illustrated Catalogue of Old and Rare Books. (Angling, pp. 12-18.) 8vo. London: 1898.

C CATALOGUES. QUARITCH (B.) Interesting Books Relating to Games, Sports, etc. 8vo. London : 1899.

CATALOGUES. RICHMOND \& CO. (G. H.) Angling and Sporting BOOKS. 8vo. New York: 1898.

CATALOGUES. RYER (FREDERICK R.) Sporting Literature. 8vo. New York: Bangs \& Co., 1889.

CATALOGUES. SABIN (JOSEPH). A Bibliographical Catalogue of the Waltonian Library belonging to the Estate of Robt. W. Coleman, deceased. 8vo. New York: 1866.

* Only 75 copies printed.

CATALOGUES. SABIN (W. W.) 1,001 Books on Angling, Being the Description of a Most Complete Collection. 12mo. London: 1882. * The Grego Collection bought by Dean Sage.

CATALOGUES. SABIN (W. W.) Books on Angling, with some few on Ichthyology. (Contains Nos. IV., VII., IX. and X.) 8vo. London : 1883-1887.

CATALOGUES. SAGE (DEAN). A Catalogne of Books on Angling. Frontispiece. Square 8vo. New York: De Vinne Press, 1896.

* Only 50 copies printed from the type. No. 22. (Another copy, No. 10.)

CATALOGUES. SATCHELL (THOMAS). The Bibliography of Izaak Walton's Complete Angler. Portrait. Sq., 8vo. London: 1882.

CATALOGUES. SCRIBNER \& WELFORD. Rural Sports, Pastimes, etc. $12 \mathrm{mo}$. New York: N. D.

CATALOGUES. SNOW (EDWIN F.) Valuable and Extensive Library of Books on Angling. 8vo. London: Sothebr, Wilkinson \& HoDGe, 1898.

CATAlOGUES. SOTHERAN \& CO. Books on Angling. 8vo. London : 1899.

CATALOGUES. SUTTON (ALBERT). Sports and Pastimes, Including Angling, Fishing, Fly-Making, etc. Illustrated Cover. 8vo. Manchester : 1899.

CATALOGUES. THORPE (HENRY). Angling, Hunting, Shooting, Natural History, etc. (Nos. 1-2.) 8vo. Brooklyn, N. Y.: 1879-1880.

CATALOGUES. TOOVEY (JAMES). English Sports and Pastimes. 12mo. London: N. D.

CATALOGUES. WALTONIAN LIBRARY. By the American Editor. [G. W. Bethune.] 12mo. N. P., N. D. (N.:Y., 1847.) 
CATALOGUES. WALTON TERCENTENARY. 1593-1893. Angling and Fishing Literature. 8vo. Manchester: Albert Sutron, 1893. * Only 25 copies printed of this edition.

CATALOGUES. WAJTONIAN COLLECTION in Lenox Library. 8vo. New York: Printed for the Trustees, 1893.

CATALOGUES. WALTON \& COTTON. Chronological Hand-List of Various Editions of the Complete Angler, etc. 1593, 1893. $16 \mathrm{mo}$. New York: Grolier Clob, 1893.

* 450 copies printed.

CATALOGUES. WATERS (B. S.) A Catalogue of his Angling Library, Typewritten, from Henry Thorpe's MS. Folio. Jamaica, L. I.: 1898.

CATAlOgUes. WESTWOOD (T.) A New Bibliotheca Piscatoria. Angling and Fishing Literature. 16mo. London: 1861.

CATALOGUES. WESTWOOD (THOS.) Bibliotheca Piscatoria. Waltonian Library. Sq. 8vo. New York: J. W. Bodton, 1873.

CATALOGUES. WESTWOOD (T.) and SATCHELL (T.) Bibliotheca Piscatoria. Books on Angling, etc. 8vo. London: W. Satchell, 1883.

CATALOGUES. WESTWOOD (T.) and SATCHELL (T.) Bibliotheca Piscatoria. 4to. London: W. Satchell, 1883.

* Large Paper Copy.

CATALOGUES. WESTWOOD ('T.) and SATCHELL ('T.) A List of Books Relating to Fish, Fishing and Fisheries, to Supplement the Bibliotheca Piscatoria published in 1883. 8vo, paper. London: SAMpson Low, 1901.

${ }^{*}$ Compiled by R. B. Marston and issued with the English Catalogue of Books for 1900.

CATALOGUES. WESTWOOD \& SATCHELL. Interleaved Copy of a List of Books Relating to Fish, Fishing and Fisheries, to Supplement the Bibliotheca Piscatoria of E. Westwood and T. Satchell. Published in 1883. 8vo. London: SAMrson Low, 1901.

CATON (JOHN DEAN, LL.D.) A Summer in Norway. Second Edition. With Map and Portrait. 8vo. Chicago : 1880.

CALLOW (AGNES). Drops of Water. Colored Plates. Sq. $16 \mathrm{mo.}$ London: 1851.

CATS (JACOB). Alle de Wercken, etc. 4to. Amsterdam: $J_{\triangle N} J_{\triangle \text { COBo }}$ SCHIPPER, 1655.

CATS (JACOB). Alle de Wercken, etc. Fol. Amsterdam: JAN JACoBo SCHIPPER, 1665. 


CAUX (J. W. DE). The Herring and the Herring Fishery. $12 \mathrm{mo.}$ London : 1881.

CHAMBERS (E. T. D.) The Ouananiche and its Canadian Environment. Illustrated. 8vo. New York: Harpers, 1896.

CHAMBERS (E. 'T. D.) The Angler's Guide to Eastern Canada. Sq. 16mo. Quebec: Morning Chronicle Office, N. D.

CHAPMAN (ABEL). Wild Norway. Illustrated by the Author. 8 vo. Edward Arnold, Publisher to the India Office, London and New York: 1897.

CHAMPON (CONSTANTIN). La Pêche en Eau Douce Ouvrage Indespensable anx Pécheurs. Illustrated. 16mo. Paris: N. D.

CHARLES (UNCLE). The Boy's Book of Sports and Games. Illustrations by Henry Sears. (Colorid). 24mo. London: Henry Allman, 1850.

CHARLETON (T. W., R. N.) Ari (The) of Fishing. A Poem. 8vo. North Shields: Printed for the A dTHOR, 1819.

CHARLETONI (GUALTERI). Onomasticon Zoicon. Plerorumque Animalinm Differentias et Nomina Propria Pluribus Linguis Exponens. Plates. Sq. 12mo. Londini : J. Allesstry, 1668.

CHARLETONI (GUALTERI). Exercitationes de Defferenties et Nominibus Animalium. Plates of Birds and Fishes Inserted. Folio. Oxionæ: E. T. Sheldonano, 1677.

[OHASSERESSE (DIANE).] Sporting Sketches. Illustrated. $12 \mathrm{mo}$. London: Macmillan, 1890.

CHASsES et Pêches Anglaises Variêtês de Pêches et de Chasses. Illustrated. 8vo. Paris: N. D.

CHATterton (G. J.) An Essay on Fly-Fishing. 12mo. Printed by Hazell, Watson \& Viney. London and Aylesbury: N. D.

[CHATTO (WM. A.)] Angler's (The) Souvenir. By P. Fisher. (pseud.) Illustrations by Beckwith \& Topham. First Edition. 16mo. London: Chas. Trut, 1835.

[CHATTO (WM. A.)] Angler's Souvenir. "A New Edition. Illustrated. 12mo. London: W ARNE \& Co., N. D.

[CHATTO (WM. A.)] Angler's Souvenir. A New Edition. Plates India Proofs. Sq. 8vo. London: Warne \& Co., N. D.

[CHATTO (WM. A.)] Rambles in Northumberland. By Stephen Oliver, the Younger. (pseud.) Illustrated. 16mo. London: 1835.

[CHATTO (WM. A.)] Scenes and Recollections of Fly-Fishing. By Stephen Oliver. (pseud.) Illustrated. 16mo. London: 1834. 
CHEEK (J.) The Young Angler's Guide. Illustrated. Second Edition. 8vo. London: 1839.

CHEEK (J.) The Young Angler's Guide. Engravings. Third Edition. 8vo. London : 1839.

CHEEK (JOHN). The British Angler's Instructor. Gratis. $32 \mathrm{mo.}$ London: HowletT \& SoN, 1855.

CHEEVER (REv. HENRY T.) The Whale and his Captors. Engravings. $18 \mathrm{mo}$. New York: 1850.

CHESSHYRE (E.) Posthumous Sougs, etc. Silhouette Portrait. $12 \mathrm{mo.}$ Manchester: Henry Jones, 1837.

[CHETHAM (JAMES)]. The Angler's Vade Mecum. A Compendious, yet full, Discourse of Angling. By a Lover of Angling. First Edition. 24mo. London: Printed for Thо. Bassetт, 1681.

[CHETHAM (JAMES)]. The Angler's Vade Mecum. The Second Edition. Illustrated with Sculptures and very much enlarged. $16 \mathrm{mo}$. London: Printed for T. Basset, 1689.

[CHETHAM (JAMES)]. The Angler's Vade Mecum. Third Edition. Illustrated with Sculptures. $16 \mathrm{mo}$. London: Printed For William BAtTERsBX, 1700.

[CHETHAM (JAMES)]. The Angler's Vade Mecum. Third Edition. 16mo. London: Printed for William Battersby, 1700.

CHITTY (EDWARD). The Illustrated Fly-Fisher's Text-Book. By Theophilus South, Gent. 23 Engravings (and 10 Woodcuts inserted). 8vo. London: Bous, 1845.

CHURCH (A. J.) Isis and Thamesis. Illustrated. First Edition. 4to. London: SeEley \& Co., 1880.

* Edition de Luxe with etched title.

CHURCH (A. J.) Summer Days on the Thames. 1llustrated. Second Edition. Sq. 8vo. London: Seelex \& Co., 1890.

CHURCHWARD (JAMES). A Big Game and Fishing Guide. Map and Illustrations. 8vo. Bangor, Maine: 1898.

* Issued by The Bangor \& Aroostook R. R.

CLARK (GEORGE). The Game Laws, from King Henry III. to the Present Period. 16mo. London: Printed for J. Fillding, 1786.

CLARK (FRANK E.) Our Vacations. 24mo. Boston: (1874.)

CLARK (N. W.) I'isciculture. An Address on the Artificial Breeding of Fish, etc. 8vo. Detroit: 1875. 

Glinton (Dewitt) Fishes of the Western States "I "Salne Olsego or Orsego Basser Eng

1815
1825 
[CLARKE (CAPTAIN).] The Angler's Desideratum-Some New and Valuable Inventions by the Author, from a Practice of Nearly Half a Century. 16mo. Edinburgh: M. Anderson, 1839.

CLARKE (KIT.) Where the Trout Hide. Illustrated. 24mo. New York: Brentano's, 1889.

CLARKE (KIT.) Practical Angler. Illustrated. 16mo. New York: 1892.

CLAVE (J.) La Pêche et la Pisciculture: Coste. Sur les Moyens de Repeupler toutes les Eaux de la France par l'eclosion Artificielle des Oeufs de Poisson: Pouchet (Geo.) La Pisciculture en France. (3 pamphlets in one volume.) 8ro. (Paris) V.D.

*From "Revue de Deux MIonde."

CLEMENTS (L.) Shooting, Yachting, and Sea-Fishing Trips. Second Series. By "Wildfowler." 2 vols. 8vo. London: Cirapman \& HALL, 1877.

CLEMENTS (L.) Shooting and Fishing Trips. By "Wildfowler." "Snap Shot." Second Edition. 8vo. Loudon: Chapman \& Hall, 1878.

CLIFFE (CHAS. F.) The Book of South Wales. Maps and Engravings. Third Edition. 16mo. London: 1854.

CLIFFE (JOHN HENRY). Notes and Recollections of an Angler. First Edition. 12mo. London : 1860.

CLIFFE (JOHN HENRY). Notes and Recollections of an Angler. Second Edition. 12mo. London: 1870.

[CLINTON (DE WITT).] Letters on the Natural History and Internal Resources of the State of New York. By Hibernicus. (psend.) $12 \mathrm{mo.}$ New York: E. Burss \& E. White, 1822.

CLOQUET' (HIPPLYTE) (sic.) Dictionnaire des Sciences Naturelles. Planches (85, beautifully colored) of Fish. 8vo. Paris: F. G. LERRADLT, 1816-1830.

[COAD (J.)] Angling (The) Excursions of Gregory Greendrake, Esq. (pserd.), in Ireland. Second Edition. 2 vols. 12mo. Dublin: Ecus $\&$ Alcock, 1826.

[COAD (J.)] Angling Excursions of Gregory Greendrake, Esq. (pseud.) Fourth Edition. Front. 12mo. Dublin: Grant \& Bolton, 1832.

COBBOLD (T. SPENCER). On the Destruction of Fish and Other Aquatic Animals by Internal Parasites. 8vo. London : Clowes, 1883.

CODFISH. A History of the Emblem of the Codfish in the Hall of the House of Representatives. 8vo. Boston: 1895. 
COLE (RALPH). The Young Angler's Pocket Companion. Folded Frontispiece in three parts. First Edition. 24mo. London : Printed FOR R. BASSAM, 1795.

COLE (RALPH). The Young Angler's Pocket Companion. Frontispiece. (four men angling). 32mo. London: Printed for W. Lane, 1795. COLE (RALPH). The Young Angler's Pocket Companion. Frontispiece. (man fishing). 24mo. London: W. MASON, N. D.

* Third Edition. With Chapter on "Smelt Fishing" which all copies do not contain.

COLLIER (J. H.) and HOOPER (J.) American Parlor Aquarium. Illustrated. 12mo. New York: J. H. Colliser, 1866.

COLQUHOUN (JOHN). The Moor and the Loch. Illustrated. First Edition. 8vo. Edin. and London: Bцıоrwood \& Sors, 1840.

COLQUHOUN (JOHN). The Moor and the Loch. Illustrated. Second Edition. 8vo. London: J. Murizay, 1841.

COLQUHOUN (JOHN). The Moor and the Loch. Illustrated. Third Edition. 8vo. Edin. and London: Blaokwood \& Sons, 1851.

COLQUHOUN (JOHN). The Moor and the Loch. Portrait and Illustrations. Sixtlı Edition, enlarged. 2 vols., $12 \mathrm{mo}$. Edin. and London: W. BLACKWOOD \& Sons, 1884.

COLQUHOUN (JOHN). Rocks and Rivers. 12mo. London : MURray, 1849.

COLQUHOUN (JOHN). Salmon-Casts and Stray Shots. 16mo. Edin. and London: Blackwood, 1858.

COLQUHOUN (JOHN). Sporting Days. 12mo. Edin. and London: BLAOKWOOD, 1866.

COLLINS (A. S.) The Impregnation of Eggs in Trout Breeding. 8 ro. N. P., N. D.

* From the American Naturalist. Vol. IV., p. 76.

COMPLE'TE (The) FAMILY-PIECE: and COUNTRY GENTLEMAN, and Farmer's Best Guide. In Three Parts. Third Edition, improved. 16mo. London: C. Rivington, 1741.

COMPLETE (The) Fisherman; or Universal Angler. Frontispiece. First Edition. 16mo. London : Fielding aNd Walker, N. D. (1778). CONCORD AND MONTREAL RAILROAD. Lakes, Ponds and Streams. Maps and Illustrations. 8vo. Concord: 1892.

CONNECIICUT (STATE OF). Report of the Commissioners Concerning the Protection of Fish in the Connecticut River, \&c. May Session, 1867. 8vo. Hartford: 1867. 
boleridge, Hanny Neloon. Six Nirnaths in The Nost Indies ni 1825 thitd Ertim 180 Loudoz Ooluellurray 1832 bollection (A.) of Scance, Curious Traluable Pieces Both ai Verse Pthose $16^{\circ}$ Edriburgh: H. Reidiniow 1773 
Conn. Second Rept, Shell Fish Conn: Sene Assembly Jan 1883

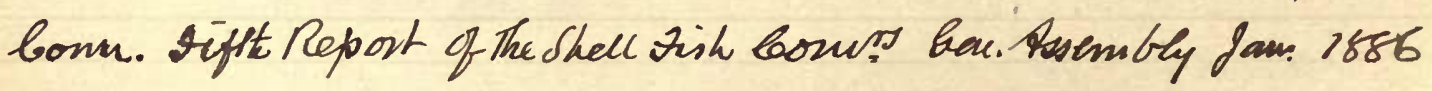

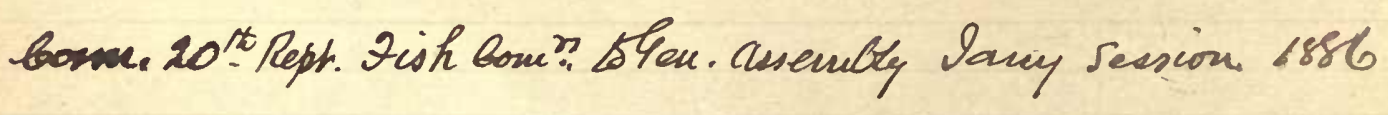


CONNECTICU'T. Report (First Annual) of the Commissioners on Fisheries to the General Assembly. May Session, 1868. 8vo. Nerw Haven: T. J. StaFford, 1868.

CONNECTICU'T. Fourth Report. Commissioners of Fisheries, 1870. 8vo. Hartford: 1870.

CONNECTICUT. Sixth Report. Commissioners of Fisheries, 1872. 8vo. Hartford: 1872.

CONNEUTICUT. Seventh Report. Commissioners of Fisheries, 1873. 8vo. Hartford : 1873.

CONNECTICUT. Eighth Report Comrs. of Fisheries, 1874. 8vo. Hartford : 1874.

CONNECTICUT. Ninth Report of the Fish Comrs., May Session, 1875. 8vo. Hartford : 1875.

CONNECTICUT. Tenth Report Fish Comrs., May Session, 1876. 8vo. Hartford: 1876.

CONNECTICUT. Eleventh Report of the Comrs. on Fisheries, 1877. 8vo. Hartford: 1877.

CONNECTICUT. Twelfth Report Comrs. on Fisheries, 1878. 8vo. Hartford : 1878.

CONNECTICUT. Sixteenth Annual Report Fish Comrs., Jan. Sess., 1882. 8vo. Hartford: 1881. (Sic.)

CONNECTICUT. Seventeenth Report Fish Comrs., Jan. Session, 1883. 8vo. Hartford : 1883.

CONNECTICUT. Eighteenth Report Fish Comrs., Jan. Sess., 1884. 8vo. Hartford : 1884.

CONNECTICUT. Nineteenth Report Fish Comrs., Jan. Sess., 1885. 8vo. Hartford: 1885.

CONNECTICUT. Twenty-First Report Fish Comrs., Jan. Sess., 1887. 8vo. Hartford: 1886. (Sic.)

CONROY (THOS. J.) Handbook for Sportsmen. Oblong 8vo. N. Y.: 1889.

CONROY (THOS. J.) Illustrated Retail Price List and Handbook for Sportsmen. Fishing and Camping. 8vo. New York: N. D.

CONWAY (JAMES). Letters from the Highlands. Illustrated. $12 \mathrm{mo.}$ London: E. LAMLEX, 1859.

CONWAY (JAMES). Forays Among Salmon and Deer. 12mo. London: Chapman and Hali, 1861. 
CONWAY (JAMES). Forays Among Salmon and Deer. New Edition. 12mo. London: Simpkin, N. D.

[COOK (CHAS. H.)] The Book of the All-Round Angler. By John Bickerdyke. 150 Engravings. 8vo. London: L. U. GILL, 1888.

[COOK (CHAS. H.)] The Book of the All-Round Angler. 150 Engravings. $12 \mathrm{mo}$. London: GiLL, N. D.

[COOK (CHAS. H.)] Days in Thule. By John Bickerdyke. Mlustrated. 16mo. Westminster: 1894.

[COOK (CHAS. H.)] Days of my Life. By John Bickerdyke. Illustrated. $12 \mathrm{mo}$. London: 1895.

[COOK (CHAS. H.)] Thames Rights and Thames Wrongs. By John Bickerdyke. Illustrations. 16mo. Westminster: 1894.

[COOK (CHAS. H.)] Sea Fishing. Illustrated. By John Bickerdyke. Sq. 8vo. London: Longmans, 1895.

*Badminton Library. Large Paper.

[COOK (CHAS. H.)] Wild Sports in Ireland. By John Bickerdyke. Illustrated. 12mo. London: L. U. GiLl, 1897.

COOK (MARC). The Wilderness Cure. 12mo. New York : 1881.

COOKSON (RICHARD). The Goosnargh Rambler. By Richard Cookson, of Goosnargh. 16mo. London: Simpkin, Marshall \& Co., 1850.

*The only copy known. "Angling," pp. 125-12\%. “The Art of Angling," pp. $137-146$.

COOPER (SARAH). Animal Life in the Sea and on the Land. Illustrated. 12mo. New York: Harpers, 1890.

COPE (E. D.) The Homologies of the Fins of Fishes. Illustrated. 8vo. N. P., May 28, 1890.

*From Am. Naturalist.

COQUET AND THE ALWINE, The Marriage of the. 12mo. Newcastle-upon-Tyne: Hodgson, 1817.

CORBALLIS (JAS. HENRY). Forty-Five Years of Sport. Illustrated. 8vo. London: Bentiey, 1891.

CORBET (HENRY). Practice (The) of Angling as Regards Ireland. Portrait. By O'Gorman. (pseud.) First Edition. 2 vols. 8vo. Dublin: Curry, 1845.

CORBET (HENRY). Practice of Angling in Ireland. By O'Gorman. (pseud.) Second Edition. Colored Front. of Grayling. 2 vols. in 1. 16mo. Dublin : Curry, 1855. 


CORNISH (J.) A View of the Present State of the Salmon and Channel Fisheries. 8vo. London: Longmans, 1824.

CORY (CHAS. B.) Hunting and Fishing in Florida. Illustrated. Sq. 8vo. Boston: 1896.

COSMOPOLITE. The Sportsman in Ireland. By a Cosmopolite. (pseud.) Illustrated. Fras' Edrtron. 2 vols. 12mo. London: H. Colburn, 1840.

COSTE (M.) Instructions Pratiques sur la Pisciculture, etc. 4 folded plates. 12mo. Paris: Vrotor Masson, 1853.

COSTE (M.) Instructions Pratiques sur la Pisciculture. Deuxieme Edition. Illustrated. 16mo. Paris: 1856.

COSTE (M.) Voyage D'Exploration sur le Littoral de la France et de L'Italie. Deuxieme Edition. Illustrated. 4to. Paris : 1861. [COTTON (CHARLES).] The Compleat Angler. Part II. 24 mo. London: Printed for Richard Marriott and Himy Brome, 1676.

*The First Edition of Charles Cotton's Contribution to the Compleat Angler.

COUCH (JONATHAN). A History of the Fishes of the British Islands. Colored Plates. 4 vols. 8vo. London: Bell \& Son, 1877. COUNTRY (The) GENTLEMAN'S COMPANION. By A Country Gentlemen. First Edition. 2 vols. 16mo. London: Printed For THY A UTHOR, 1753.

COUN'TRY NOTES. A Journal of Natural History and Outdoor Observations. 7 Parts. 4to. Manchester: 1882.

* Reprinted from The Manchester Oity Neros.

COX (I. E. B.) Facts and Useful Hints relating to Fishing and Shooting. Illustrated. First Edition. 12mo. London: Horace Cox, 1866. COX (I. E. B.) Angler's Diary and Fisherman's Guide. 12mo. London : H. Cox, 1871.

COX (I. E. B.) Angler's Diary and Fisherman's Guide. 12mo. London : “The Finid" Office, 1877.

COX (I. E. B.) Angler's Diary and Tourist Fisherman's Gazetteer. 12 mo. London : H. Cox, 1899.

COX (I. E. B.) Angler's Diary and Fisherman's Guide. 12mo. London : "The Freld" Offioe, N. D.

COX (NICHOLAS). The Gentleman's Recreation. In Four Parts, viz.: Hunting, Hawking, Fowling, Fishing. Illustrated. Second Edition. 12mo. London: Printed вX J. C. for N. C., 1677.

COX (NICHOLAS). Gentleman's Recreation. Illustrated. Fifth Edition. 12mo. London: Printed by F. Collins for N. C., 1706. 
COX (NICHOLAS). Gentleman's Recreation. Illustrated. Sixth Edition. 12mo. London: Printed for N. C. by J. Wilcox, 1721.

COXON (HENRY). A Modern Treatise on Practical Coarse Fish Angling. Illustrated. 8vo. Nottingham: 1896.

CRANE (STEPHEN). A Fishing Village [pp. 71-77 in "The Philistine," Aug., 1899]. Sq. 24mo. East Aurora, N. Y.: 1899.

CRAWFORD (J. H.) Wild Life of Scotland. Illustrated. 8vo. London : J. Macquen, 1896.

CRAWFURD (OSWALD JOHN FREDERICK). Country House Essays. By John Latouche. (pseud.). 16mo. London: W ARD, Lock \& 'TrLoR, (1876).

CRAWFURD (OSWALD, Editor.) A Year of Sport and Natural History, Fishing, etc. Illustrated. 4to. London: Chapman \& Hall, 1895.

CRAWHALL (JOS.) A Collection of Right Merrie Garlands for North Country Anglers. 12mo. Newcastle-on-Tyne: G. Rutuand, 1864.

CRAWHALL (JOS.) A Collection of Right Merrie Garlands for North Country Anglers. Illustrated. 4to. Newcastle-on-Tyne: G. RutIAND, 1864.

* Only 50 copies printed. No. 27.

CRAWHALL (JOS.) Chaplets from Coquet-Side. Colored Head and Tail Pieces, etc. 8vo. (Newcastle-on-Tyne) 1873.

CRAWHALL (JOS.) Border Notes and Mixty-Maxty. Facsimile MS. and Colored Engravings. Sq. 8vo. Newcastle-on-Tyne: 1880.

* Fifty printed and plates destroyed.

[CRAWHALI, (JOS.)] The Compleatest Angling Booke that euer was writ. Adorned with Sculptures. 4to. N. P. (1881).

CRAWHALL (JOS.) The Compleatest Angling Booke that euer was writ. Colored and other illustrations. 4to. N. P., 1881. :

* Of this Edition only 100 copies were printed.

CRAWHALL (JOS.) Izaak Walton, His Wallet Booke. Colored cuts taken from old wood blocks. 16mo. London: Field \& Tuer, 1885. CRONISE (TITUS FEY). The Natural Wealth of California. 4to. San Francisco : 1868.

CROSS (D. WV) Fifty Years with the Gun and Rod. 12mo. Cleve. land : 1880.

CRUMPLEN (THOMAS). A Paper on the Causes of the Apparent Diminution of Fish in the River Thames. 8vo. London (1881).

CUBLEY (J. S.) How to Fish. 16mo. Birmingham: 1873. 



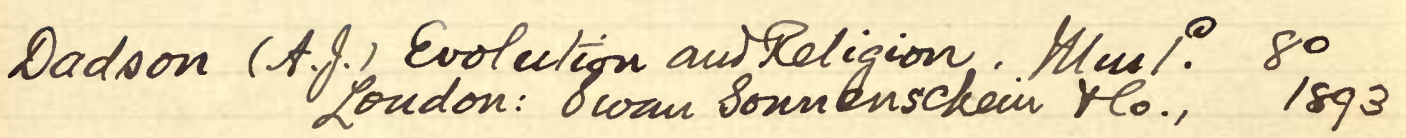

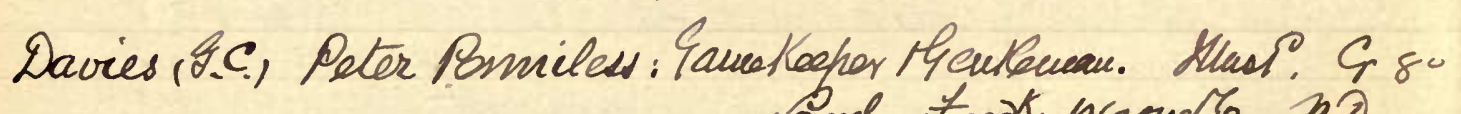
soud. Areat. Warueto ho. 
CUMMING (C. F. GORDON). Two Happy Years in Ceylon. Illustrated. 2 vols., 8vo. Edin. and Lond.: 1892.

CUMMINS (W.J.) Catalogue of Salmon and Trout Rods, etc. Illustrations. $12 \mathrm{mo}$. Bishop Auckland: N. D.

CUMMINS (W. J.) Catalogue of Superior Salmon and Trout Rods, etc. Illustrated. Sq. 8vo. Bishop Auckland: N. D.

CUSSAC (R. J.) Pisciceptologie ou L'Art de la Pêche a la Ligne, etc. Par J. C ${ }^{* * *}$ (pseud.) Deuxieme Édition. Numerous illustrations. 16mo. Paris : 1820.

CUTLIFFE (H. C.) The Art of Tront Fishing on Rapid Streams. First Edition. 16mo. South Molton: W. Tucker, 1863.

CUTLIFFE (H. C.) The Art of Trout Fishing on Rapid Streams. Second Edition. 16mo. London: Sampson Low, 1883.

CUVIER (LE BARON) and VALENCIENNES (M.) Histoire Naturelle des Poissons. 24 vols., 4to. Paris: Chez F. G. Terradlt, 1828-1849.

CUVIER AND VALENCIENNES. The colored plates of fishes to "Histoire Naturelle des Poissons." 4to. N. P., N. D.

AMON (WM. E.) Ocean Wonders. Illustrated. 12mo. New York: Appleton, 1879.

DANCE (CHAS.) Izaak Walton. A Drama. Etching of Walton, Cotton, and the Milk Maid, by Pierce Egan. 12mo. London: Chapman \& Hall, (1839.)

DANIEL (REv. WM. B.) Rural Sports and Supplement, Containing the Part on Angling. Portrait and Fine Plates. 4 vols., 4to. London: Bunny \& Gold, 1801-1813.

DAVIES (G. C.) Mountain, Meadow and Mere. 16 Illustrations. Second Edition. 12mo. London: H. S. King \& Co., 1874.

DAVIES (G. C.) Angling Idylls. 8vo. London : Chapman \& Hall, 1876.

DAVIES (G. C.) Hand-Book to the Rivers and Broads of Norfolk and Suffolk. Map and Illustrations. Seventh Edition. 12mo. London: JARROLD \& SoNs, (1882.)

DAVIES (G. CHRISTOPHER). Fishing. Illustrated. 16mo. London : Dean \& Son, N. D.

DAVIS (WM. M.) Nimrod of the Sea. Illustrated. 12mo. New York HARPER, 1874. 
[DAVY (SIR HUMPHREY).] Salmonia; or Days of Fly-Fishing. Illustrated. By an Angler. First Edition. 16mo. London: J. Morrat, 1828.

[DAVY (SIR HUMPHREY).] Salmonia; or Days of Fly-Fishing. Illustrated. Second Edition. 16mo. London: J. Murrat, 1829.

[DAVY (SIR HUMPHREY).] Salmonia; or Days of Fly-Fishing. Third Edition. 16mo. London: J. Murray, 1832.

[DAVY (SIR HUMPHREY).] Salmonia; or Days of Fly-Fishing. Illustrated. First American from the Second London Edition. $16 \mathrm{mo}$. Phila.: CAREY \& LeA, 1832.

DAVY (SIR HUMPHREY). Collected Works. Edited by his Brother John Dary. Vol. IX. "Salmonia and Consolations in Travel." Plates. 8vo. London: Sмith, Elder \& Co., 1840.

DAVY (SIR HUMPHREY). Salmonia. Fourth Edition. With Illustrations. 16mo. London: J. MUrray, 1851.

DAVY (SIR HUMPHREY). Salmonia: With Illustrations. Second American Edition. 16mo. Boston: Roberts Bros., 1870.

DAVY (JOHN). Angler (The) and His Friend. 16mo. London: Longmans, 1855.

DAVY (JOHN). Angler (The) in the Lake District. 16mo. London : Longmans, 1857.

DAWSON (GEORGE). Pleasures of Angling. Illustrated. $12 \mathrm{mo.}$ New York: Sheldon \& Co., 1876.

DAWSON (GEORGE). Angling Talks. 12mo. New York: "Forest \& STreaM," 1883.

DAX (Le Vie LOUIS De). Nouveaux Souvenirs de Chasse et de Pêche. Illustrated. 12mo. Paris: 1860.

DAY (FRANCIS). Fishes of Malabar. Plates On-colored. 4to. London: 1865.

DAY (FRANCIS). Fishes of Malabar. Colored Plates. 4to. London: QUARITCH, 1865.

DAY (FRANCIS). The Fishes of Great Britain and Ireland. Numerous Plates. 2 vols. 4to. London and Edinburgh: 1880-1884.

DAY (FRANCIS). The Commercial Sea Fishes of Great Britain. 8vo. London: 1884.

DAY (FRANCIS). Fish Culture. Illustrated. 8vo. London: CLowes \& Sons, 1883.

DAY (FRANCIS). British and Irish Salmonidx. Twelve Plates. 4to. London and Edinburgh : 1887. 


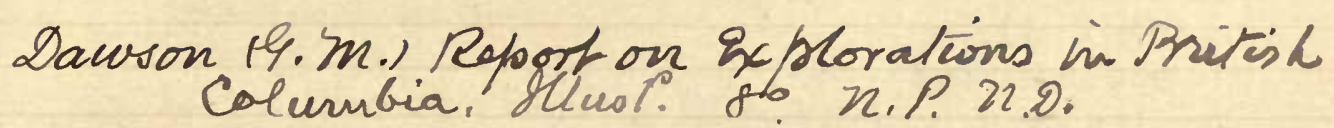




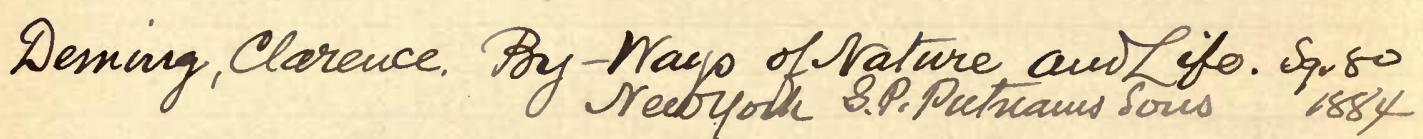


DEACON (W.F.) Inn-Keeper's (The) Album. 8ro. London: Tros. MoLean, 1823.

DEAN (BASHFORD). Fishes, Living and Fossil. Illustrated. 8vo. New York : Macmillan, 1895.

DEBETTA (EDOARDO). Ittiologia Veronese Ad Uso Popolare e Per Servire Alla Introduzione Della Piscicultura Nella Provincia. Seconda Edizione. 8ro. Verona: 1862.

DeFOLIN (Lw MARQUIS). Pêches et Chasses Zoologiques. $117 \mathrm{En}$ gravings. 12mo. Paris : 1893.

DEHERRYPON (MARTIAL). La Bontique de la Marchande de Poissons. $12 \mathrm{mo}$. Paris: 1867.

DEKAY (JAS. E.) Zoology of New York. The Fishes. Plates Beautifully Colored. 2 vols. 4to. Albany: 1842.

DEMPSTER (HENRY). The Deck-Welled Fishing Boat. Plans. 16no. Glasgow : Aird \& Coguin., 1868.

D. [ENNYS] J. [OHN]. The Secrets of Angling; By J. D., Esqre. Augmented by W. Lawson. 8vo. London: Printed by T. H. for John Harison, 1652. Reprinten for Roвt. Triphook, 1811.

* Only 100 copies of this reprint done.

DENNYS (JOHN). The Secrets of Angling, 1613. A Reprint, with Introduction by Thos. Westwood. 4to. London: 1883.

DENN YS (JOHN). Secrets of Angling. 2 vols. in 1. 16mo. Edin.: Privately Printed, 1885.

* Small paper. Bib. Curiosa.

DENNYS (JOHN). Secrets of Angling; Edited by Piscator. 2 vols. in 1. 8vo. Privateliy Printed. Edin.: 1885.

* "Bibliotheca Curiosa" Reprints. Large PaPer.

DENNYS (JOHN). Secrets of Angling. 2 vols. in 1. 16mo. Edin.: E. \& G. GoldsMid, 1885.

DENVER, LEADVILLE \& GUNNISON RAILWAY. Trouting in Colorado Waters. Illustrated. 8vo. Kansas City, Mo., N. D.

DESCRIPTION OF ELIZABETH ISLANDS IN BUZZARD'S BAY. Map. 8vo. New York: JAMes VAN ORden, 1836.

DESCRIPTION (A) of More than Three Hundred Animals, including Quadrupeds, Birds, Fishes, Serpents, and Insects. Illustrated after the style of Bewick and A. Anderson. 16rno. London: B. \& R. Crosby, 1812.

* Lacks last three leaves.

DETZEM ET BERTOL. Fecondation Artificielle du Poisson, etc. (Several pamphlets in 1 vol.) 4to. N. P., N. D. 
DE VOE (THOS. F.) The Market Book. Sq. 8vo. (Vol. 1, all published.) New York: For the Adrhor, 1862.

DEWAR (GEO. A. B.) The Book of the Dry Fly. Illustrated. 8vo. London : 1897.

DEWAR (GEO. A. B.) In Pursuit of the Trout. Illustrated. $16 \mathrm{mo.}$ London: J. M. Dent \& Co., 1898.

DEW AR (GEO. A. B.) The South Country Trout Streams. Mlustrated.

12mo. London: Lawrence \& Bullen, 1899.

D'EWES (J.) Sporting in Both Hemispheres. Tinted Plates. $16 \mathrm{mo.}$ London : RoutLFDGe, 1858.

DEWHURST (HENRY WM.) Natural History of the Order Cetacea. Illustrated. 8vo. London: Poblisued by the Author, 1834.

DEYEUX (TH.) Le Vieux Pêcheur. Illustrated. 16mo. Paris: HoNDaILLe, 1837.

DICK (CAP'I. ST. JOHN). Flies and Fly Fishing. Illustrated. $12 \mathrm{mo.}$ London: H. HARDWICKE, 1873.

DICTIONNAIRE THEORIQUE ET PRATIQUE DE CHASSE et de Pesche. 2 vols., 16mo. Paris : Chez I. B. G. Musier, $17 ̧ 69$.

DICTIONARIUM, RUSTICUM, URBANICUM ET BO'TANICUM ; Or a Dictionary of Husbandry, etc. Illustrated. Second Edition. 12mo. London: J. Nicholson, 1717.

DIXON (JOHN). Improvement of the Fisheries. Letter V. (British Empire). 4to. London: G. \& W. Nicol by J. Brettell, 1804.

DOBSON (WM.) Rambles by the Ribble. Three Series in 1 vol. (Second Edition of first, Third Thousand of the second, and first of the third). 12mo. Preston: 1844-1883.

DOMINION OF CANADA. Reports on the Fisheries, etc. 8vo. Ottawa: 1868.

DOMINION OF CANADA. Third Annual Report of the Dept. of Marine and Fisheries. Year Ending June 30, 1870. 8vo. Ottawa: 1871.

DOMINION OF CANADA. Fourth Annual Report of the Dept. of Marine and Fisheries. Year Ending June 30, 1871. 8ro. Ottawa: 1872.

DOMINION OF CANADA. Fifth Annual Report of the Dept. of Marine and Fisheries. Year Ending June 30, 1872. 8ro. Ottawa: 1873. 
Aouovan, E. Natural History of Bitis tishes. 120 benitifully Glored plates. Srols bound in 2. Sidow. for the Clattor 1802

$-1808$ 
DOMINION OF CANADA. Supplement No. 4. Eighth Annual Report of the Minister of Marine and Fisheries. Year 1875. 8vo. Ottawa: 1876.

DOMINION OF CANADA. Supplement No. 4 to the Ninth Annual Report of the Minister of: Marine and Fisheries. Year 1876. Svo. Ottawa : 1877.

DOMINION OF CANADA. Supplement No. 4 to the Eleventh Annual Report of the Minister of Marine and Fisheries. Year 1878. 8vo. Ottawa: 1879.

DOMINION OF CANADA. Supplement No. 2 to the Eleventh Annual Report of the Minister of Marine and Fisheries. Year 1880. 8vo. Ottawa : 1881.

DOMINION OF CANADA. Supplement No. 2 to the Fourteenth Annual Report of the Dept. of Marine and Fisheries. Year 1881. 8vo. Ottawa : 1882.

DOMINION OF CANADA. Supplement No. 2 to the Fifteenth Annual Report of the Dept. of Marine and Fisheries. Year 1882. 8vo. Ottawa: 1883.

DOMINION OF CANADA. First Annual Report of the Dept. of Fisheries. Year 1884. 8vo. Ottawa: 1885.

DOMINION OF CANADA. Third Annual Report of the Dept. of Fisheries. Year 1886. 8vo. Ottawa: 1887.

DOMINION OF CANADA. Special Report on the Fisheries Protection Service of Canada, 1886. 8vo. Ottawa: MoLiean, Roger \& Co., 1887. DOMINION OF CANADA. Sixth Annual Report of the Dept. of Fisheries. Year 1889. 8vo. Ottawa: 1890.

DOMINION OF CANADA. Ontario Game and Fish Commission. Commissioners' Report. 8vo. 'Toronto: 1892.

DOMINION OF CANADA. Thirtieth Annual Report of the Dept. of Marine and Fisheries, 1897. 8vo. Ottawa : 1898.

DORAN (JOS. I.) Our Fishery Rights in the North Atlantic- 8vo. Phila.: 1888.

D'ORBIGNY (ALCIDE). Voyage dans L'Amerique Meridionale Poissons Valenciennes. Colored Plates. Folio. Paris: C. P. Bertrand, 1847.

DOTTIE (ROBT.) The Rambles and Recollections of " $\mathrm{R}$ " Dick. Illustrated. 12mo. Manchester: 1898.

[DOUBLEDAY (THOS.)] Coquet-Dale (The) Fishing Songs. By a North Country Angler. 12mo. Edin. and London: BLAokwood, 1852. 
DOUGALL (JAS. DALZIEL). Salmon and Trout Angling. Front. of Hooks. First Edition. 16mo. Edinburgh: CaLdwell, Lloyd \& Co., 1841.

DOVETON (F. B.) A Fisherman's Fancies. 12mo. London: E. STOCK, 1895.

DRAKE (SAM'L ADAMS). Nooks and Corners of the New England Coast. Illustrated. 3vo. New York: HARPERs, (1875).

DRAKE (S. A.) The Pine-Tree Coast. Illustrated. 8vo. Boston: Estes \& LaURiat, 1891.

DREAM OF THE THREE SILVER TROUTS. New Edition. Illustrated. $32 \mathrm{mo}$. London: Houlston and Stoneman, N. D.

DRYDEN (ADAM). Hints to Anglers. Maps. 24mo. Edinburgh: A. \& C. BLACK, 1862.

DU BARTAS. His Diune Weekes and Workes Translated. Engraved Title by W. Hole, and Printer's Device at end, and Portrait. Sq. 12mo. London: Printed by Humfrey Lownes, 1613.

DUBOIS (A.) La Pêche a la Ligne en Eau Douce Suivie de la Culture Des Eaux. Illustrations. 4to. Paris: 1894.

DU MONCEAU (M. DUHAMEL). Traité Général des Pêches, et Historie Des Poissons. Illustrated. Fol. A Paris: 1769.

DYER (T. F. THIS'TLE'TON). Great Men at Play. 2 vols. 8vo. London: Remington, 1889.

[DYKES (THOS.)] Stories of Scottish Sports. By "Rockwood." $12 \mathrm{mo.}$ Glasgow: D. Bryce \& Son, 1881.

7 ASTON (EDWARD). Rivers Conservation. Address and Papers L Read Before the British Association at Dublin, 1878. 8vo. London: P. S. King, 1878.

EDINBURGH ANGLING CLUB. Rules and Regulations of. Sq. 8vo. Edin.: 1856.

EDINBURGH ANGLING CLUB. Songs of. Illustrated. 8vo. Edin.: 1878.

EDINBURGH ANGLING CLUB. Songs and Selections from the Albums of. Illustrated. 8vo. Edin.: D. Dodalas, 1900.

EDWARDS (ARTHUR M.) Life Beneath the Waters. Illustrated. 12mo. New York: 1858.

EDWARDS-MOSS (JOHN E.) A Season in Sutherland. $12 \mathrm{mo.}$ London and New York: 1888. 


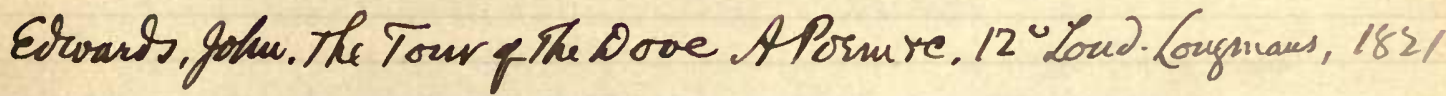


Eliof. Sanil. (Editioby) Portiny ForChildrow Kust 180 Bostoù: Leershepard. 1880 
EHRENTREUTZ (BARoN V.) Das Ganze der Ungelfischerei nnd ihrer Geheimnisse, ober Vollständige Unleitung die Ungelfischerei, etc. Plates. 12mo. Leipzig: 1852.

EIGENMANN (CARL H. and ROSA S.) A Revision of the South American Nematognathi, or Cat Fishes. 8vo. San Francisco: 1890.

EIGENMANN (CARL H.) and BEESON (CHAS. H.) The Fishes of Indiana. 8vo. Indianapolis: W. B. Burford, N. D.

ELLACOMBE (Rev. H. N.) Shakespeare as an Angler. Front. $16 \mathrm{mo.}$ London: E. STоск, 1883.

ELLIOT (H.) 'The Complete Angler, How, When and Where to Take the Best Kinds of Fish. Illustrations. 24mo. London: H. Elliot, 1855 .

ELLIOT (H.) The Complete Angler. Illustrations. 24mo. London: G. Purkiss, N. D.

ELLIOTT (CHAS. B.) United States and Northeastern Fisheries. Map. 8vo. Minneapolis : 1887.

ELLIOTT (Hon. WM.) Carolina Sports. Illustrated. 12mo. New York : Derby \& JACKsON, 1859.

ELLIOTT (HoN. WM.) Carolina Sports. 12mo. London: BeNTLEY, 1867.

ELLSWORTH. Maine, and Green Lake, the Tourists', Anglers' and Hunters' Paradise. Illustrated. Oblong 24mo. Camden, Me.: G. H. HAYNes, 1889.

EMERTON (JAS. H.) Life on the Seashore. Illustrated. $12 \mathrm{mo}$. Salem, Mass.: 1880.

ENCYCLOPEDIE HISTOIRE NATURELLE. REPTILES ET POISSONS. M. E. Desmarest. Numerous Engravings. 4 to. Paris: N. D.

ENCYCLOPEDIE METHODIQUE. Histoire Naturelle. Tome Troisieme. Contenant les Poissons. 4to. A Paris: Chez Panckoucke, A. Liege: Chez Plomteux, 1787.

ENCYCLOPÉDIE MÉTHODIQUE. Dictionnaire de Toutes les Espèces de Pêches. 2 vols. 4to. (vol. I., Texte, vol. II., Planches). A Paris: Chez H. Agasse and Chez Panckoucke, 1793.

ENGLAND AND WALES. Report by Frank Buckland and Spencer Walpole, Inspectors of Fisheries for England and Wales, and Comrs. for Sea Fisheries-on the Sea Fisheries of England and Wales. 8vo. London : 1879. 
ENGLAND AND WALES. Salmon Fisheries. Eighteenth Annual Report of the Inspectors. Year 1878. 8vo. London: 1879.

ENGLAND AND WALES. Salmon Fisheries. Ninetecnth Annual Report of the Inspectors. 1879. 8vo. London: 1880.

ENGLISHMAN'S MAGAZINE (The). 4to. London: JAs. Burns, 1841. EPICURE. The Innocent. Angling, a Poem. Second Edition. $16 \mathrm{mo}$. London: Slater, 1741.

ERIE. Fishing on the Picturesque Erie. Illustrated. 8ro. N. Y.: 1898.

ERIE RAILROAD COMPANY. Rural Summer Homes on the Picturesque Erie. Illustrated. 4to. New York: D. I. RoвkRrs, 1898.

ESSAY. An Essay on the Right of Angling in the River Thames, etc. 8vo. Reading: Printed by Smalit \& Cowglade, N. D.

[ETTINGSALL (THOS.)] The Angling Philosopher. By T. E. $12 \mathrm{mo}$ (4 pp.) Dublin: J. Charles, N. D.

EVANS (W.) Art of Angling (The). A New Edition Revised and Corrected. Front. 12mo. London: J. Richardson, N. D.

EVANS (W.) Art of Angling. A New Edition Revised and Corrected. Front. 12mo. Uxbridge: Printed by Wm. Lake, N. D.

EWART (J. C., M. D.) The Preservation of Fish. 12mo. London: C. Griffin \& Co., 1887.

EXPERIMENTS. New and Excellent Experiments and Secrets in the Art of Angling. 2 Engravings. Narrow 24mo. London: Printed IN THE Y YAR 1675.

*Taken from "The Accomplished Ladies Delight." 1675. pp. 205-237. It is a First Edition.

FABER (G. L.) The Fisherics of the Adriatic. Illustrated. 4 to. London: QUARITOH, 1883.

FAIRCHILI (G. M., JR.) Rod and Canoe, Rille and Snowshoe, in Quebec's Adirondacks. Illustrated. Sq. 16mo. Quebec: FranK CARREL, 1896.

FAIRFAX (Mr. 'T.) The Complete Sportsman. Front. First Edition. (Circa 1760). 16mo. London: J. Cooke, N. D.

FAIRFAX (J., should be T'.) The Complete Sportsinan. A New Edition, Revised, Corrected and Improved. 16mo. London: Printed For the Proprietors, 1795. 
Everman BW. Reporf ow Investigations by the Unied States

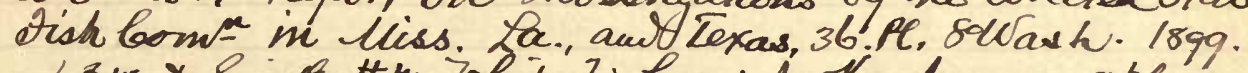

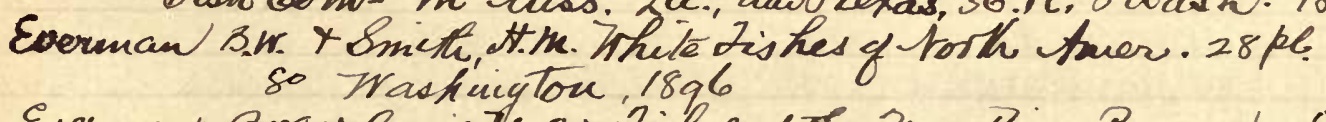

Evermant Bn) + box ( Te.0.) Tiokes of The Mo. Rever Bason so Washicig Tou 1896 


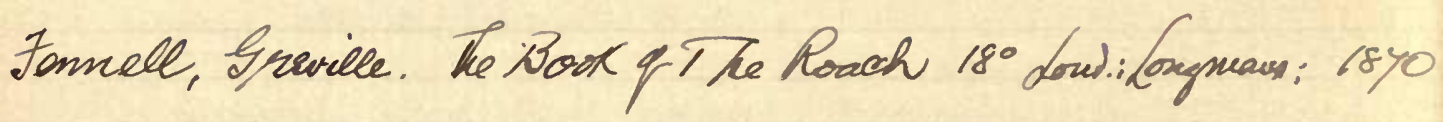


FAMILY RECEIPT-BOOK (The New.) A New Edition. $16 \mathrm{mo.}$ London: J. Murrat, 1811.

FARRAR (CHAS. A. J.) Eastward, Ho! or, Adventures at Rangeley Lakes. Illustrated. 16mo. Boston: LeE \& SHePard, 1880.

FARRAR (CHAS. A. J.) Camp Life in the Wilderness. 12 Illustrations. 16mo. Boston: A. Williams \& Co., 1882.

FARRAR (CHAS. A. J.) Wild Woods Life. Illustrated. $16 \mathrm{mo.}$ Boston: Lee \& Shepard, 1884.

FARRAR (CHAS. A. J.) From Lake to Lake. 30 Illustrations. $12 \mathrm{mo.}$ Jamaica Plain, Mass.: 1887.

FARRAR (CHAS. A. J.) Illustrated Guide Book to Moosehead Lake. Map. Sq. 12mo. Boston: Lee \& Shepard, 1889.

FARRAR (CHAS. A. J.) Through the Wilds. Illustrated. Sq. 8vo. Boston: Estes \& Lauriat, (1892.)

FEA (JAMES). Considerations on the Fisheries in the Scotch Islands. Map. 8vo. London: Printed for the Author at Dover, 1787.

[FENNELT, (GREVILLE)]. Rail and the Rod. No. 1. Great Eastern Railway. By Greville F. (Barnes). 12mo. London: H. Cox, 1867.

[FENNELL (GREVILLE)]. Rail and the Rod. No. 2. Great Western Railway. By Greville F. (Barnes). 12mo. London: H. Cox, 1867. [FENNELL (GREVILLE)]. Rail and the Rod. No. 3. Southwestern Railway. By Greville F. (Barnes). 12mo. London: H. Cox, 1867. [FENNELL (GREVILLE)]. Rail and Rod. No. 4. Southeastern Railway, etc. By Greville F. (Barnes). 12mo. London : H. Cox, 1869. [FENNELL (GREVILLE)]. Rail and Rod. No. 6. Great Eastern, Midland, London and Northwestern and Great Northern Railways. By Greville F. (Barnes). 12mo. London: H. Cox, 1871.

FIELD (EUGENE). Love Affairs of a Bibliomaniac. First Edition. 16mo. New York: Ĺcribners, 1896.

FIELD (EUGENE). Love Affairs of a Bibliomaniac. 12mo. New New : Soribners, 1896.

First Edition. Edition of 150 Copies on Holland Paper, No. 133.

FINLEY (GEO.) The German or European Carp. 12mo. Pittsburg: 1882.

FISCH-HOOK. Le Livre du Pêcheur. Avec Nombreuses Illustrations. 16mo. Paris : N. D.

FISH. How Caught, Cooked and Cornered. 8ro. London: J. A. Brook \& Co., N. D. 
FISH RECIPES. Published by the Fishing Gazette. 16mo. New York: N. D.

FISHER (MaJ. A. T.) Rod and River; or, Fly-Fishing for Salmon, Trout and Grayling. 8ro. London: Bentlex, 1892.

FISHER (ARTHUR T.) Outdoor Life in England. 8vo. London: Bentlex, 1896.

FISHER (JAS.) A Spring Day. Second Edition. Portrait and Engravings. 8vo. Edin.: For the Author, 1806.

FISHER (JAS.) A Spring Day. Portrait and Engravings. Fifth Edition. 8vo. Liverpool: 1819.

FISHER (W. T.) The Art of Trolling; or Practical Pointers for Anglers. 24mo. Athens \& Sayre, Pa.: N. D.

FISHERIES. An 1 Uustrated Article taken from "Chambers' Information for the People." 4to. N. P., N. D.

FISHERIES QUESTION, Correspondence Relative to. 1885-87. Presented to Parliament by Command of His Excellency the Gov. Gen., 3d May, 1887. 8ro. Ottawa: 1887.

FISHES, Flowers and Fire. (The Phallic Series.) 12mo. London: Privately printed by A. Reader, 1890.

FISHES. The Book of Fishes (Class Pisces). First Edition. Illustrated. 24mo. London: JohN W. PArker, 1834.

FISHES. The Book of Fishes. Illustrated. Second Editon. 24mo. London: JoHN W. PARKer, 1835.

FISHES. The Part Relating to Fishes from Cassell's Natural History. Illustrated. 4to. N. P., N. D.

FISHING GAZETTE. Edited by R. B. Marston. Illustrated. Vols. 39 and 40. 2 vols. Folio. London: 1899-1900.

FISHING GAZETTE. Vols. 11 to $16 . \quad$ In Seren Volumes. 4to. New York: 1894-99.

FISHING : When, Where, and How to Fish Without Live Bait. Illustrated. Square 16mo. London: Joseph Thrckbroom, 1861.

* The imprint on cover is London: Wm. Tweedie, 1862.

FITTIS (ROBT. SCOTT). Sports and Pastimes of Scotland. Square 8vo. Paisley and London: 1891.

[FITZGIBBON (EDWARD).] A Handbook of Angling. By Ephemera. First Edition. 16mo. London: Longmans, 1847.

[FITZGIBBON (EDWARD).] A Handbook of Angling. Second Edition. 16mo. London: Longmans, 1848. 
Fishmongers (Company of), The Charter, Bye-Laws, Sift, Appointments re, of the, 4- London: 1490. 
Aleming, fohm. Alistony Pritis timals. 80 Eocie. 1828

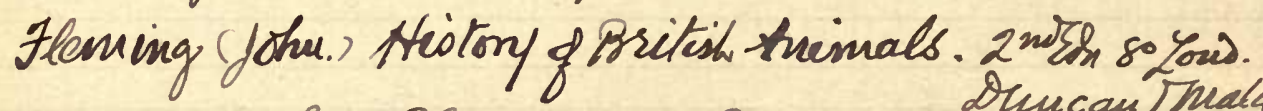

Duncau Thealcolone 1842

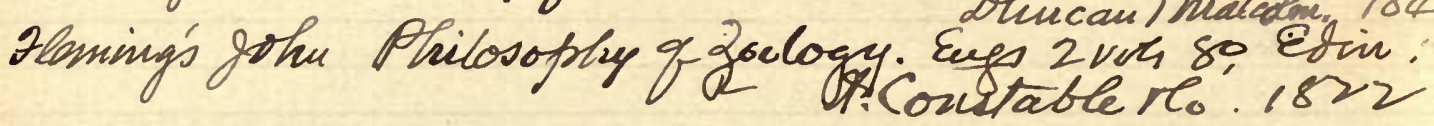

Florida. Fish y Fisheries of the coustal waters of Florida. Senate wo 100.80 . Wash. Tany 78.1897 .9 Price Senet 7 lorida. Aisheries of Indian Revier. 94 . Brice. Benate soc. ho 46.8 Jan. 5.1897 is pl. Washingtow 189," 
FITZGIBBON (EDWARD). The Book of the Salmon. Colored Plates. By Ephemera. 16mo. London: Longmans, 1850.

[FITZGIBBON (EDWARD).] A Handbook of Angling. Third Edition. 16mo. London: Longmans, 1853.

[FITZGIBBON (EDWARD).] $\Lambda$ Handbook of Angling. By Ephemera. Fourth Edition. 16mo. London : Longmans, 1865.

FITZPATRICK (B. M.) Irish Sport and Sportsmen. New Edition.

Portrait. 8vo. Dublin: M. H. Gili \& Son, 1879.

FLAGG (WILSON). Studies in the Field and Forest. 12mo. Boston : Little, Brown \& Co., 1857.

FLAGG (WILSON). Halcyon Days 12mo. Boston: 1881.

FLETCHER (PHINEAS). The Purple Island. Together with 'Piscatorie Eclogs, etc. By P.F. Finst Edition (with the rare $2 \mathrm{pp}$. by Francis Quarles at end). Sq. 12mo. Printed by the Printers to tue Universitie of Cambridge, 1633.

FLETCHER (PHINEHAS). Piscatory Eclogues, with other Poetical Miscellanies. Vignette on title. 12mo. Eton: Printed For A. KinCAID \& W. CREECH, 1771.

FLORIDA. The Fishes of Florida. Special Illustrated Edition of The American Angler. 4to. New York: Jan. 1, 1884.

FLOWERDEW (HENRY). The Parr and Salmon Controversy. $12 \mathrm{mo.}$ Edinburgh: T. \& T. ClaRK, 1871.

FLOWERDEW (HENRY). The Parr, Salmon, Whitling and Yellow Fin Controversy. Second Edition. 12mo. Manchester and London: 1883.

FLY-FISHERS' CLUB. Our House Warming. 2 Illustrations. Sq. 12mo. London: The Fly-Fishers' Club, 1888.

* Edited by C. H. C. [ook], (John Bickerdyke).

FLY-FISHING in Salt and Fresh Water. Six Colored Plates of Flies. 8vo. London: J. VAN Voorst, 1851.

FLY MAKER'S HANDBOOK. Illustrated with Colored Plates. By Angler. 24mo. Liverpool: N. D.

FORD (S. D. D.) Piscatio, or Angling. A Poem. 12mo. Oxford: LeoN LichField, 1733.

FORD (THOS.) Trout-Fishing. 12mo. London: E. Pitman, (1881).

FORES' SPORTING NOTES ÁND SKLTCHES. A Quarterly Magazine Descriptive of British and Foreign Sport. Illustrated by $F$. Mason and R. M. Alexander. 9 vols., 8vo. London: Messrs. Fores, 1885-1892. 
FOREST (GEO.) Every Boy's Book. Opward of 600 Illustrations. 12mo. London: Rootledge, 1855.

FOREST AND STREAM FABLES. Illustrated. 8vo. New York: Forest and Stream, 1886.

FORESTER (THOMAS). Norway and Its Scenery. Plates. $12 \mathrm{mo.}$ London: BoHN, 1853.

FORESTER (THOS.) A Road-Book for Tourists in Norway. $16 \mathrm{mo}$. London: ВонN, 1854.

* Taken from "Norway and Its Scenery."

FOSTER (DAVID). Scientific (The) Angler. I'ortrait and Illustrations. 12mo. London and Derby: (1882).

FOSTER (DAVID). Scientific (The) Angler. Illustrated. Edited by Wm. C. Harris. 12mo. New York: O. Judd Co., 1883.

FOS'TER (DAVID). Scientific (The) Angler. Portrait and 1llustrations. Third Edition. 12mo. London and Derby : (1886).

FOS'IER (DAVID). Scientific (The) Angler. Portrait and Illustrations. Fifth Edition (inclusive of the American issue). Fourth English Edition. 12mo. London and Derby : N. D.

FOS'TER (W. A.) Songs on Angling, etc. 8vo. New York: 1886.

Twenty-five copies privately reprinted (by J. A. Logan) from "Whistle Binkie" and The Book of Scottish Songs.

FOS'TER'S Catalogue of the Renowned Specialties in Fishing Tackle. Illustrated. 8vo. Derby and London: 1900.

FRAICHE (FELIX). Traité des Procédés de Multiplication, Naturelle et Artificielle des Poissons, etc. Illustrations. 16mo. Paris: N. D.

[FRANCE (L. B.)] With Rod and Line in Colorado Waters. Illustrations. 12mo. Denver: 1884.

FRANCE (L. B.) Mountain Trails and Parks in Colorado. Illustrated. 12mo. Denver, Col.: 1887.

FRANCIS (FRANCIS). The Angler's Register and Almanac. $16 \mathrm{mo.}$ London: Field CFFice, 1860.

FRANCIS (FRANCIS). Fish-Culture. Illustrations. 12mo. London: Rodtledee, 1863.

FRANCIS (FRANCIS). Fish-Culture. Second Edition. Illustrated. 12mo. London: Routledge, 1865.

FRANCIS (FRANCIS). A Book on Angling. Second Edition. Illustrated. 12mo. London: Longmans, 1867.

FRANCIS (FRANCIS). By Lake and River. 12mo. London : "The Field" Office, 1874. 


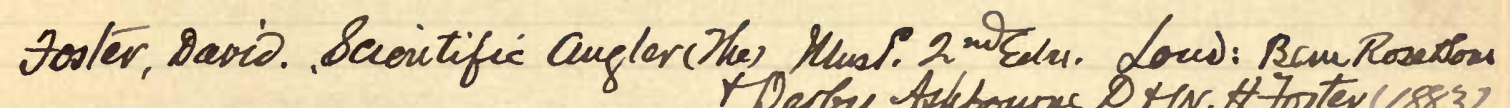

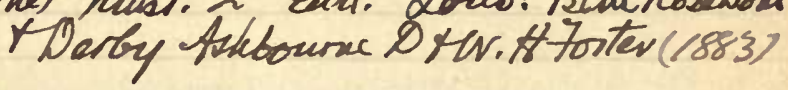


Fraser (Duncan) Reiverside Rambles of In Elinburgh sugler. Mustrated. 12 'Beltiert: Feo. Lewis Hon, 1895

Fkorbel, feclies Seven Yearis Travel nubentral America. Te Hensi- 8: Loud. Rich? Benley, 1859 
FRANCIS (FRANCIS). A Book on Angling. Fourth Edition. Illustrated. 12mo. London: Longmans, 1876.

FRANCIS (FRANCIS) and Cooper (A. W.) Sporting Sketches with Pen and Pencil. 4to. London: "The Field" Office, 1878.

FRANCIS (FRANCIS). A Book on Angling. Fifth Edition. Illustrated. 12mo. London: Longmans, 1880.

FRANCIS (FRANCIS). Hot Pot, etc. 12mo. London: "FIELD" OfFice, 1880.

FRANCIS (FRANCIS). Angling. Second Edition. 12mo. London: H. Cox, 1883.

FRANCIS (FRANCIS). Practical Management of Fisheries. Illustrated. 12mo. London: H. Cox, 1883.

FRANCIS (FRANCIS). Angling Reminiscences. 12mo. London: H. Cox, 1887.

FRANCIS (H. R.) The Fly-Fisher and His Library. [In "Cambridge Essays" for 1856, pp. 233-260.] 8vo. London: J. W. Parker \& Son, 1856.

FRANCK (RICHARD). Northern Memoirs. To which is added The Contemplative and Practical Angler. New Edition. 8vo. Edinburgh: Constable \& Co., 1821.

FRASER (ALEXANDER). Natural History of the Salmon, Herrings, Cod, Ling, etc. Second Edition. 12mo. Inverness: For tHE A UTHOR, 1833.

FRASER (ROBERT). A Review of the Domestic Fisheries of Great Britain and Ireland. Chart. 4to. Edinburgh: Peter Hill \& Co., 1818.

FRASER (REV. ROBT. W.). The Seaside Naturalist. Illustrated. 12mo. London: Virtue \& Co., 1868.

FREEBOOTER (THE). With an illustration to each number. Nos.1-24. 8vo. Oct., 1823, to Mch., 1824. N. P. (London): B. Jonnson, 1823-4.

FRENCH AND ENGLISH PAMPHLE'TS on Fishes. "Coup d'EEil sur les Origines de la Pisciculture Flnviale," N. Toly. "Rapport sur les Etablissements de Pisciculture, etc.," A. M. E. Leroy, etc. Plates. 8vo. V.P., V. D. (7).

FROST (JOHN). Grand Illustrated Encyclopedia of Animated Nature. 1350 illustrations. 4to. N. Y. and Auburn: 1856.

FRY (W. H.) A Complete Treatise on Artificial Fish-Breeding. Illustrated. 12mo. New York: Appleton, 1854. 
FRY (W. H.) A Complete Treatise on Artificial Fish-Breeding. Illustrated. 12mo. New York: Appleton, 1866.

FUR, FIN AND FEA'IHER. Containing the Game Laws, etc. 8vo. New York : 1868.

FUR-SEAL and Other Fisheries of Alaska. Maps and illustrations. 8vo. Washington: 1889.

FYLDES (REV. W.) Dove Dale and Other Dales. Illustrated. $12 \mathrm{mo.}$ Buxton and London (1897).

CALBERT (M. LE COMTE DE) Documents de Pisciculture ApplicI ables a 'Toutes les Masses D'Eaux. Avec Plan et Legende. 8vo. Grenoble: 1863.

GALE (FREDERICK.) Modern English Sports. Photo-Portrait. 12mo. London: SAMPson Low, 1885.

GAME FISHES OF THE WEST. "American Angler." 4to. N. Y.: 1886.

GARLICK (THEODATUS.) A Treatise on the Artificial Propagation of Fish. Illustrated. 8vo. Cleveland: 1857.

GARLICK (THEODATUS.) A Treatise on the Artificial Propagation of Fish. Illustrated. Second Edition. 8vo. New York: A. O. MOORE, 1858.

GARLICK (THEODATUS.) A Treatise on the Artificial Propagation of Fish. Illustrated. Second Edition. 8ro. Cleveland: I. B. SAVAGE, 1880.

* This is really the Third Edition-Second Cleveland Edition.

GARMAN (SAMUEL.) The American Salmon and Trout. Illustrated. 8vo. Boston: 1885 .

GASTECLOUX (P.) La Pêche a la Ligne. En Siene et en Marne et dans les Grands Cours D'Eau. Sq. 12mo. Paris: 1886.

GATHORNE-HARDY (HoN. A. E.) The Salmon-Law of Salmon Fishing by C. D. Pennant, etc. Illustrated. 12mo. London: LONGMANS, 1897.

* Fur, Feather, and Fin Series."

GATHORNE-HARDY (HoN. A. E.) Autumns in Argyleshire with Rod and Gun. Illustrations. 8vo. London: Longmans, 1900.

GAUCKLER (PH.) Les Poissons D'Eau Douce et la Pisciculture. Tllustrations. 8vo. Paris: 1881.

GAY (JOHN.) Rural Sports. Twenty-five copies only printed. Sq. 12mo. Cambridge: 1880. 
Gale (Aredorick) 8/20010 Alecreations in Town Tountry. zivit Eliviox. 160 Louvon: Swan Sornenschion, Loweritlo

Sarman At. On Feographic Surttes. 80 Lexinglon.thy (1890) 
Gerard (das. W.) Optrea; or The Loves of The Oysters. A Lay By A. Dis ke Shelly, Esq-120 New Yots: T.Y. Crowens, 1857 Sibort, Chas. At. Fishes of The Klamatt (orgou) Rever Basiv. Hens: inf. 80 . Trashuy tow 1898 
GEDNEY (C. W.) Angling Holidays. In Pursuit of Salmon, Trout and Pike. Illustrated. First Edition. 8vo. "Telegraph" Printing Works. Bromley, Kent: 1896.

GENTLEMAN (THE) ANGLER. By a Gentleman who has made Angling his Diversion upwards of Twenty-eight Years. 16mo. London: A. Bettesworth, 1726.

GENTLEMAN ('THE) ANGLER. By a Gentleman who has made it his Diversion for Fourteen Years. Frontispiect. 16mo. London: G. Kearsley, 1786.

GENTLEMAN(THE) ANGLER. By a Gentleman who has made Angling his Diversion upwards of Twenty-eight Years. Third Edition. $16 \mathrm{mo}$. London: C. Hiтch, N. D.

GENTLEMAN (THE) FARMER. Written by a Person of Honour in the County of Norfolk. 16mo. London: E. CurLL, 1726.

GENTLEMAN (THE) FISHER. Second Edition. 12mo. London: H. CURLL, 1727.

GERVAIS (H.) and Boulart (R.) Les Poissons Synomie-Description Moeurs-Frai-Pêche-Iconographie. Colored Plates. 4to. Paris: J. RothsCHILD, 1876.

GIBSON (W. HAMILTON.) Camp Life in the Woods, Trapping, etc. Illustrated by the author. Sq. 16mo. New York: Harpers, 1882. GILL (THEODORE.) Arrangement of the Family of Fishes. 8vo. Washington: Smithsonian Institution, 1872.

GILL (THEODORE.) Catalogue of the Fishes of the East Coast of North America. 8vo. Washington: Smitusonian Institution, 1873. GILL (THEODORE.) Günther's Literature and Morphography of Fishes. 12mo. New York:" Forest and Stream, 1881.

[GILLMORE (PARKER.)] Accessible Field Sports. By "Ubique." Front. and Vig. 12mo. London: Chapman \& Hall, 1869.

[GILLMORE (PARKER.)] Gun, Rod, and Saddle. By Ubique. 12mo. London: Chapman \& Hall, 1869.

[GILLMORE (PARKER.)] Gun, Rod, and Saddle. Front. $12 \mathrm{mo.}$ New York: W. A. Townsend \& Adams, 1869.

GILLMORE (PARKER, "UBIQUE.") Gun, Rod, and Saddle. Second Edition. 12mo. London: Gibbings \& Co., 1896.

GILLMORE (PARKER, "UBIQUE.") Leaves from a Sportsman's Diary. Second Edition. Portrait. 12mo. London: Gibings \& Co., 1896 : 
GILLMORE (PARKER, "UBIQUE.") Prairie and Forest. Illustrated. 12mo. London: Chapman \& HaLL, 1874.

GILLMORE (PARKER, "UBIQUE.") Prairie and Forest. Illustrated. 12mo. New York: HARPERs, 1874.

GILLMORE (PARKER, "UBIQUE.") Prairie and Forest. Third Edition. Illustrated. 12mo. London: Gibbings \& Co., 1896.

[GILPIN (WILLIAM).] Three Dialogues on the Amusements of Clergymen. By Jos. Frampton. (pseud.) First Edition. 16mo. London: Printed for B. \& J. White, 1796.

[GILPIN (WILLIAM).] Three Dialogues on the Amusements of Clergymen. By Jos. Frampton. (pseud.) Second Edition. $16 \mathrm{mo.}$ London: T. CADELL, 1797.

[GILPIN (WILLIAM).] On Amusements of Clergymen, and Christians in General. By Edward Stillingfleet. ( pseud.), Lord Bishop of Worcester. $12 \mathrm{mo}$. London: A. J. V $\triangle$ ALPY, 1820.

GIRARD (Dr. C.) Report on the Fishes Collected on the Survey Pacific Railroad. Plates. 4to. Washington, 1857-60.

GIRARD (CHARLES, M. D.) Fishes of the Pacific Railroad Reports. 1llustrated. 4to. Washington: 1858.

GIRARD (CHARLES). Ichthyology of the Boundary Survey. U. S. \& Mexican. Plates. 4to. N. P., N. D.

GLENFIN. (pseud.) The Fishing-Rod. By Glenfin. 16mo. London: BaILEY Bros., 1860.

GLENFIN. ( $p$ seud.) The Fishing-Rod. Second Edition. 16mo. London: Bailey Bros. and Houlston \& WRIGHT, 1861.

*A change of imprint and date is the only apparent difference in the tro Editions.

GLENFIN. ( pseud.) The Fishing-Rod. Fourth Thousand. 16mo. London: Houlston \& Wright, 1865.

GOBIN (A.) La Pisciculture en Eaux Douces. 93 Illustrations. 16mo. Paris: 1889.

GODFREY (EDWARD K.) The Island of Nantucket. With Maps of the Town and Land. 16mo. Boston : Lee \& Shepand, 1882.

GOÜAN (Mr. ANTOINE). Histoire des Poissons, la Description Anatomique de leurs parties Externes and Internes, and le Caractere des divers Generes ranges par Classes and par Ordres. Plates. Sq. 8vo. Strasbourg: Amand KöNia, 1770.

GOLDSMITH (OLIVER). Animated Nature. Illustrated. 8vo. London: T. TEGG, 1825.

*This is Vol. XV. of the Complete Works of Oliver Goldsmith. 
Givicel

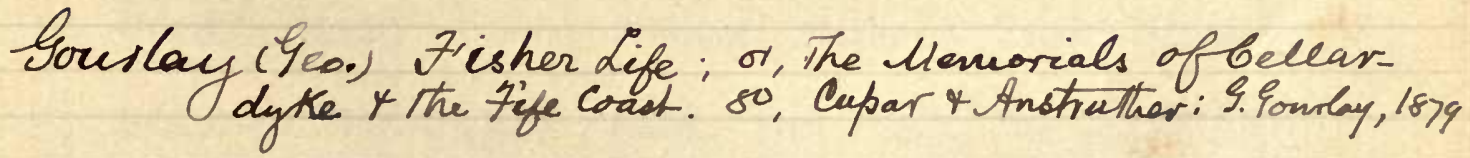



GOMPERTS (LEWIS). Fragments in Defence of Animals, and Essays on Morals, Soul, and Future State. Engravings. 16mo. London: W. Horsele, 1852.

GOODE (G. BROWN). American Fisheries. A History of the Menhaden, (and) "The Agricultural Uses of Fish." By A. O. Atwater. 30 Plates. 8vo. New York: O. Judd Co., 1880.

GOODE (G. BROWN). Exhibit of the Fisheries and Fish Culture of the U. S. America at the International Fischerei-Ausstellung. Berlin, April 20, 1880. 8vo. Washington : 1880.

GOODE (G. BROWN). Materials for a History of the Mackerel Fishery. 8vo. Washington: 1883.

*Associated with Prof. Goode were Joseph W. Collins, R. E. Earle, and A. Howard Clark.

GOODE (GEO. BROWN). Fisheries and Fishery Industries of the U. S. Section III. The Fishing Grounds of North America. With 49 Charts. Edited by Richard Rathbun. 4to. Washington: 1887.

GOODE (G. BROWN). American Fisheries. A Popular Treatise Upon the Game and Food Fishes of North America. Colored Front. and Numerous Engravings. Sq. 8vo. New York: Standard Book Co., 1888.

[GOODRICH (S. G.)] The Every Day Book for Youth. By Peter Parley. (pseud.) Engravings. Sq. 16mo. Philadelphia: Haswelc, 1838.

GORDON (Mrs.) "Christopher North." A Memoir of John Wilson. Portrait. 12mo. New York: W. J. Widnleton, 1863.

GOSSE (PHILIP HENRY). The Aquarium. Colored Lithographs. 12mo. London: VaN Voorst, 1854.

GOSSE (P. H.) The Ocean. 52 I llustrations. From the Last London Edition. 12mo. Philadelphia: Parry \& McMillan, 1856.

GOSSE (PHILIP HENRY). Life in Its Lower, Intermediate, and Higher Forms. 12mo. New York: Carter \& Bros., 1857.

GOSSE (PHILIP HENRY). A Year at the Shore. 36 Colored Illustrations. 12mo. London: A. Strahan, 1865.

GOULD (JOHN M.) How to Camp Out. Illustrations. 16mo. New York: Scribner, Armstrong \& Co., 1877.

GOULD (NAT.) Sporting Sketches. Illustrated. 12mo. London : R. A. Everett \& Co., 1900.

GOURIET (EDOUARD). Théses. First Théses. Recherches Experimentales sur la Locomotion des Poissons. 4to. Niort: 1866. 
GRAND 'TRUNK RAILWAY SYSTEM. Guide to the Fishing and Hunting Resorts. Illustrated. 12mo. N. P. Season 1898.

GRANBY. The Tront. By the Marquess of Granby, etc: Illustrated. New Edition. 12mo. London: Longmans, 1899.

GRANT (ROBERT). Jack in the Bush; or, a Summer on a Salmon River. Illustrated. First Edition. 12mo. Boston: Jordan, Marsh \& Co., 1888.

GRANT. Review of President Grant's Recent Message to the U. S. Congress, Relative to the Canadian Fisheries and the Navigation of the St. Lawrence River. 8vo. N. P., N. D.

GRAY (WM. C.) Camp-Fire Musings. Illustrated. Second Edition. Sq. 12mo. Edinburgh : David Douglas, 1894.

GRAY (WM. C.) Camp-Fire Musings. Illustrated. Sq. 12mo. New York and Chicago : 1894.

GRAZIER. The Complete Grazier, or Gentleman and Farmer's Directory. 16mo. London: Printed for J. Almon, 1767.

*First Edition. Under "Grazier," Bib. Pis. puts the date " 1677 "; evidently a transposition of the figures.

GREA'T INDUSTRIES OF THE UNITED STATES. Over 500 Illustrations. 8vo. Hartford, Chicago and Cincinnati: 1872.

*Fish Culture, Tackle, etc.

GREAT NORTHERN RAILIVAY. Fishing and Shooting Along the Line. Illustrated. Sq. 16mo. St. Paul, Minn.: 1898.

GREEN (SETH). Trout Culture. Portrait. 8vo. Rochester: Curtis, Morex \& Co., 1870.

GREEN (SETH). Fish Culture. Brook Trout. (Taken from the Last Report of the Dept. of Agriculture.) Svo. N. P., N. D.

GREEN (SE'TH). Home Fishing and Home Waters. 12mo. New York: O. JoDD \& Co., 1888.

GREENWOOD (JAMES). Wild Sports of the World. 147 Illustrations. 8vo. New York: Harpers, 1870.

GREGORY (Mr. JOHN), Works of. Curious Engravings, ne of A Monk-Fisir. Sq. 12mo. London: T. Wilidams, 1671.

GRESHAM ANGLING SOCIE'YY. A Paper on the Causes of the Apparent Diminution of Fish in the River Thames. Illustrations. 12mo. London: Hardine, N. D.

GREVILLE (LADY, EDr'ED BY.) The Gentlewoman's Book of Sports. Portraits. 12mo. London: Henry \& Co., N. D. 


GREY (SIR EDWARD). Fly-Fishing. Illustrated. 12mo. London: J. M. Dent \& Co., 1899.

[GREY DRAKE]. ( $p$ seud.) A Concise, Practical Treatise on Artificial Fly-Fishing. 8vo. London: G. Berger, (1860).

GRIFFITHS (ROGER). An Essay to Prove that the Jurisdiction and Conservacy of the River Thames, etc., is Committed to the Lord Mayor and City of London, etc. 12mo. London: R. BRown, 1746. GRIMBLE (A.) Shooting and Salmon Fishing. Illustrated. 8vo. London: Chapman \& Hall, 1892.

GUILLEMARD (N.) La Pêche a la Ligne et au Filet dans les Eaux Douces de la France. 50 Vignettes. 16mo. Paris: 1557.

GUNN (WM.) and McLEOD (N. G.), Report of. Appointed to Enquire into the Herring Fishing Industry of Great Britain and Ireland. 1889. Illustrated. 8vo. Ottawa: Brown Chamberlain, 1889.

H. (R.) The School of Recreation; or, The Gentleman's Tutor. Frontispiece. 24mo. London: Printed for H. Rodes, 1684.

* First Edition. In this copy the printer's name is spelled "Rodes." Bibl. Pisc. spells it "Rhodes."

H. (R.) Angler's Sure Guide; or, Angling Improved. Copper Cuts. By R. H., Esqre., near 40 years a Practitioner in this Art. $16 \mathrm{mo}$. London: Printed by J. H. for G. Confers, 1706.

* Sometimes attributed to Robert Howlett.

HAIME (JULES). The History of Fish Culture in Europe, from Its Earlier Records to 1854. Plates. 8vo. (Washington, 1874.)

* Other writers on this subject, included here, T. Sondakevicz, M. BouchonBrandely, Jas. W. Milner, R. Hessel, and C. G. Atkins.

HALE (CAPTAIN). How to Tie Salmon Flies. With Illustrated Directions. 8vo. London: Sampson Low, 1892.

HALFORD (FREDERIC M.) Floating Flies and How to Dress Them. 90 Hand-Colored Filies. 8vo. London: SAMpson Low, 1886.

HALFORD (FREDERIC M.) Floating Flies and How to Dress Them. 90 Hand-Colored Engravings. 8vo. New York: Scribner \& WelFORD, 1886.

* Large paper.

HALFORD (FREDERIC M.) Floating Flies and How to Dress Them. 90 Hand-Colored Engravings. 8vo. London: SAMpson Low, 1886. *Large Paper.

HALFORD (FREDERIC M.) Dry Fly.Fishing. 25 I'lates. Second Edition. 8vo. London: Sampson Low, 1889. 
HALFORD (FREDERIC M.) Making a Fishery. Portrait and Illustrations. 8vo. London: H. Cox, 1895.

HALL (BRADNOCK). Fish-Tails and Some True Ones. An Original Etching by the Author and 12 1llustrations by T. Hope McLachlan. 12mo. London and New York: E. ArNold, 1897.

HALL (HERBERT BYNG). Scottish Sports and Pastimes. Illustrations. 16mo. London: John \& Daniel A. Darlina, 1850.

[HALL (HERBERT BYNG)]. Sport and its Pleasures. Front. and Vig. by the Author of "Highland Sports," "Sayah," etc. First Edition. 16mo. London: Chapman \& Hali, 1859.

[HALL (HERBERT BYNG)]. Sport and its Pleasures. Front. and Vig. Second Edition. 16mo. London: W. Mrtchell \& Co., 1868.

HALL (HERBER'T BYNG). Highland Sports. Illustrated. 2 vols. 12mo. London: H. Hurst, N. D.

HALL (PETER). The Thames Jolly Angler. Illustrated. $12 \mathrm{mo.}$ Prospect Row, Henry St., Pentonville, N. D.

HALL (Mr. \& Mrs. S. C.) The Book of South Wales, the Wye and the Coast. Illustrated. Sq. 8vo. London: A. Hall, Vrrtue \& Co., 1861.

HALL (Mr. \& Mrs. S. C.) The Book of the Thames. Numerous Illustrations. New Edition. Sq. 8vo. London: Virtue \& Co., N. D. HALLOCK (CHAS.) The Fishing Tourist. Illustrations. 12mo. New York: HARPERs, 1873.

HALLOCK (CHAS.) Camp Life in Florida. Map. 12mo. (New York) Forest and StreaM, 1876.

HALLOCK (CHAS.) The Sportsman's Gazetteer and General Guide. Portrait and Maps. 12mo. New York: Forest and Stream, 1877. HALLOCK (CHAS.) The Sportsman's Gazetteer and General Guide. Revised. Illustrated. 12mo. New York: Oranat Jodd Co., 1883.

HALLOCK (CHAS.) The Salmon Fisher. 24mo. Few York: Harris Publishina Co., 1890.

HALLOCK (CHAS.) Vacation Rambles in Northern Michigan. Narrow 8vo. Published by the Grand Rapids \& Ind. Railroad, N. D.

HAMILTON (EDWARD, M. D.) Recollections of Fly-Fishing for Salmon, Trout and Grayling. Mezzotint Eingraving by F. S. Maden. 12mo. New York: Orange Judd Co., 1885.

HAMILTON (EDWARD, M.D.) The Riverside Naturalist. Numerous Woodcuts. 8ro. London: Sampson Low, 1890. 


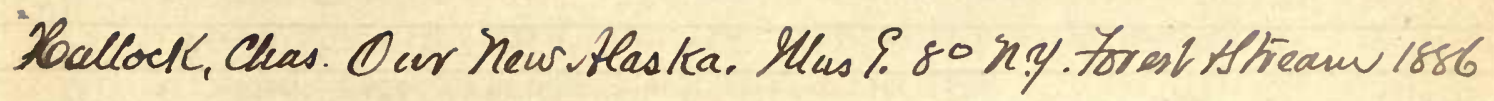



HAMILTON (JAS., D.D., F. L. S.) Memoirs of the Life of James Wilson. Portrait. 12mo. London: J. Nisber \& Co., 1859.

HAMILTON (ROBT., M.D.) The Natural History of British Fishes. Finely colored plates. 2 vols., 16mo. Edin.: W. H. Lizars, 1843.

* First Edition, as published in Jardine's Naturalist's Library.

HAMMOND (S. H.) Hills, Lakes and Forest Streams. Illustrated. 12mo. New York: J. C. Derby, 1854.

HAMMOND (S. H.) and MANSFIELD (L. W.) Country Margins and Rambles of a Journalist. 12mo. New York: J. C. Derby, 1855.

HAMMOND (S. H.) Hunting Adventures in the Northern Wilds. Illustrated. 12mo. New York: Derby \& JAckson, 1856.

HAMMOND (S. H.) Wild Northern Scenes. Front. 12mo. New York: Derrby \& JACkson, 1857.

HAMMOND (S. H.) Hunting Adventures in the Northern Wilds. Illustrated. 12mo. New York: Derby \& J JCKson, 1859.

HAMMOND (S. H.) Hunting Adventures in the Northern Wilds. Front. 12mo. Phila.: Kerstone Publishing Co., 1890.

HANDBOOK OF FISHING. Illustrated. 24mo. London: CAsseLL, N. D.

HANSARD (GEO. AGAR). Trout and Salmon Fishing in Wales. 16mo. London: Longmans, 1834.

HARDY (Lieut. CAMPBELL). Sporting Adventures in the New World. Two Colored Frontispieces. 2 vols., 12mo. London: Hurst \& BLACKETT, 1855.

HARDY (CAPTAIN CAMPBELL). Forest Life in Acadie. Front. of Trout, Colored, and other Illustrations. 8vo. London: CHAPMaN \& HALL, 1869.

HARDY (CAPTAIN CAMPBELL). Forest Life in Acadie. Front. of Trout, Colored, and other Illustrations. 8vo. New York: ApPLETON \& Co., 1869.

HARDY BROS.' Catalogue of Angling Specialties. Illustrated. 8vo. Ashbourne: 1900.

HAREWOOD (HARRY). (pseud.) A Dictionary or Sports. Illustrated. 16mo. London: Thos. Teqa \& Son, 1835.

HARKIS (WM. C.) The Angler's Guide and Tourist's Gazetteer, 1886. 12mo. New York and Chicago: 1886.

HARPER (JOHN). The Seaside and Aquarium. Illustrated. Second Edition. 16mo. Edin. and London: Nrmmo, 1859. 
HARPER (JOHN). Glimpses of Ocean Life. Illustrated with tinted plates by the Author. 16mo. London: T. Nelson \& Sons, 1861.

HARTT (CH. FRED.) Geology and Physical Geography of Brazil. Illustrations and Maps. 8vo. Boston: Fields, Osgood \& Co., 1870.

HARTUNG (EDWARD). Der Praktische Angler. 24mo. Leipzig: 1864.

HARTWIG (Dr. G.) The Sea and its Living Wonders. Woodcuts and Chromo-lithographic Plates by H. N. Humphreys. 8vo. London: Longmans, 1860.

HARVEY-BROWN (J. A.) The Wonderful Trout. 16mo. Edin.: David Douglas, 1898.

HARVEY (REv. M.) Across Newfoundland with the Governor. 8vo. St. John's, Newfoundland: 1879.

HA'TON (JOS.) and HARVEY (REv. M.) Newfoundland. Reprinted from the English Edition. Illustrated. 8vo. Boston: Doyle \& Whittle, 1883.

[HAWES (WM. P.)] Sporting Scenes and Sundry Sketches of J. Cypress, Jr. (pseud.) 4 plates. 2 vols., 12mo. New York: Gousd, BANKs \& Co., 1842.

HAWKER (LreUt.-CoL. P.) Instructions to Young Sportsmen. Illus. trated. Third Edition. 4to. London: Longmans, 1824.

* Large paper.

HAWKER (Lieut.-Cor. P.) Instructions to Young Sportsmen. Illustrated. Fifth Edition. 8vo. London: Longmans, 1826.

HAWKER (Lieut.-Cor. P.) Instructions to Young Sportsmen. Illustrated. 8vo. London: Longmans, 1830.

HA WKER (Lieut.-Col. P.) Instructions to Young Sportsmen. Illustrated. Seventh Edition. 8vo. London: Longmans, 1833.

HAWKER (LIEUT.-CoL. P.) Instructions to Young Sportsmen. 'Eighth Edition. Plates and Woodcuts. 8vo. London: Longmans, 1838.

HAWKER (LreUT.-CoL. P.) Instructions to Young Sportsmen. Edited by his Son. Illustrated. 8vo. London: Longmans, 1859.

HAXO (LE DOCTEUR). Fécondation Artificielle et Eclosion des Oenfs de Poissons. New Edition. 8vo. Epinal : 1853.

HAYES (Prest. R. B.) Message on the Newfoundland Fisheries. 8 vo. Washington: 1880 .

HEAD (GEO.) Forest Scenes and Incidents in the Wilds of North America. 16mo. London: John Murray, 1829. 


HEADLEY (J. T.) The Adirondack. Illustrated. 12mo. New York: Baker \& Soribner, 1849.

HEADLEY (REv. J. T.) Letters from the Backwoods and the Adirondack. Portrait. 12mo. New York: J. S. TAYLor, 1850.

HEADLEY (J. T.) The Adirondack. Illustrated. Second Edition. 12mo. New York: Baker \& Scribner, 1853.

HEADLEY (J. 'T.) The Adirondack. Illustrated. New and Enlarged Edition (Third). 12mo. New York: Cha8. Soribner, 1864.

HEARDER'S (J. N.) Guide to Sea Fishing and the Rivers of South Devon. Fifth Edition. 24mo. Plymouth: N. D.

HEARDER \& SONS. Guide to Sea Fishing and the Rivers of South Devon. Illustrated Chart of Tackle, etc. Seventh Edition. $32 \mathrm{mo.}$ Plymouth: N. D.

HEILPRIN (ANGELO). The Animal Life of Our Sea Shore. Illustrated. 12mo. Phila. : J. B. Lippincotт \& Co., 1888.

HENDERSON (HOWARD). Practical Hints on Camping. Illustrated. 12mo. Chicago: JaNSEN, McCluRG \& Co., 1882.

HENDERSON (WM.) My Life as an Angler. Illustrations by Clement Burlison. Engraved by Edmund Yates. 12mo. London: Spotriswoode \& Co., 1876.

* For private circulation only.

HENDERSON (WM.) My Life as an Angler. Illustrated. 8vo. London: W. Satchell, Pexton \& Co., 1879.

HENDERSON (WM.) My Life as an Angler. Woodbury Portrait and 67 Woodcuts. 8vo. London: W. Satchels, Peyton \& Co., 1879. * Large paper copy, No. 13.

HENDERSON (WILLIAM). My Life as an Angler. Woodbury Portrait and 6y Woodouts. 4to. London: W. Satohell, Peyton \& Co., 1879.

* Author's large paper copy.

HENDERSON (WM.) My Life as an Angler. Woodbury Portrait and 12 Woodcuts engraved by Edmund Yates. A New Edition. 12mo. London:- W M. Satchell \& Co., 1880.

HENSHALL (JAS. A., M.D.) Book of the Black Bass. Illustrated. 12mo. Cincinnati : Robt. Clarke \& Co., 1881.

HENSHALL (JAS. A., M.D.) Book of the Black Bass. Illustrated. 4to. Cincinnati: Robt. Clarke Co., 1889.

* Large Paper Copy.

HENSHALL (JAS. A., M.D.) Camping and Cruising in Florida. Illustrated. 12mo. Cincinnati: Robt. Clarke \& Co., 1884. 
HENSHALL (JAS. A., M.D.) Book of the Black Bass. Illustrated. 12mo. Cincinnati: The Robt. Clarke Co., 1889.

HENSHALL (JAS. A., M.D.) More About the Black Bass. Illustrated. 4to. Cincinnati: Robt. Clarke \& Co., 1889.

* Large Paper Copy.

HENSHALL (JAS. A., M.D.) Ye Gods and Little Fishes. Design by J. L. Ludlow. 8vo. Cincinnati: 'l'he Robt. Clarke Co., 1900.

HEPWOR'TH (GEO. H.) Starboard and Port. Illustrated. $12 \mathrm{mo.}$ New York: Harpers, 1876.

HERBERT (DAVID). Fish and Fisheries. A Selection from Prize Essays of the International Fisheries Exhibition, Edinburgh, 1882. Maps and Illustrations. 8vo. Edin. and London: BLAckwoon \& Sons, 1883.

HERBERT (HENRY WM., Editor). The Magnolia for 1837. Fine Steel Engravings. 12mo. New York: BANCROFT \& Hollex, (1837).

HERBERT (HENRY WILLIAM). Frank Forester's Fish and Fishing. Illustrated. 8vo. London: Ir. Bentley, 1849.

* First English Edition. Plates inserted.

HERBERT (HENRY WM.) Frank Forester's Field Sports of the United States and British Provinces of North America. Illustrated by the Author. 2 vols. 8vo. New York: Stringer \& TownSEND, 1849.

* First Edition (American).

HERBERT (HENRY WM.) Frank Forester's Fish and Fishing. Illustrated by the Author. First American Edition. 8vo. New York: Stringer \& Townsend, 1850.

HERBERT (HENRY WM.) Supplement to Frank Forester's Fish and Fishing. Plate of Colored Flies. First Edition. 8vo. New York: Stringer \& Townsend, 1850.

HERBERT (HENRY WM.) Frank Forester's Fish and Fishing. Illustrated. Third Edition with Supplement. 8vo. New York: Stringer \& Townsend, 1851.

HERBERT (HENRY WM.) Frank Forester's Fish and Fishing. Illustrated. Third Edition with Supplement. Svo. New York: Stringer \& Townsend, 1855.

* Fourth Edition (?). Identical with Edition of 1851.

HERBER'T (HENRY WM.) Frank Forester's Fish and Fishing. Illustrated. A New Edition, with a Treatise on Fly-Fishing. By " Dinks." 8vo. New York: W. A. Townsend \& Co., 1859. 

.

, 
HERBERT (HENRY WM.) Frank Forester's Fish and Fishing. Illustrated. New Edition, with a Treatise on Fly-Fishing. By "Dinks." 8vo. New York: W. A. Townsend \& Co., 1866.

HERBER'T (HENRY WM.) American Game in its Seasons. Illustrated. 12mo. New York: Chas. Scribner, 1853.

HERBERT (HENRY WM.) American Game in its Seasons. Illustrated. Revised Edition. New York: G. E. Woodward and Orange Jund Co., 1873.

[HERBERT (HENRY WM.)] Complete Manual for Young Sportsmen. By Frank Forester. 1llustrated. First Edition. 12mo. New York: Stringer \& 'Townsend, 1856.

[HERBER'T (HENRY WM.)] Complete Manual for Young Sportsmen. By Frank Forester. Illustrated. Second Edition. $12 \mathrm{mo}$. New York: W. A. Townsend \& Co., 1859.

[HERBER'T (HENRY WM.)] Complete Manual for Young Sportsmen. By Frank Forester. Illustrated. 12mo. New York: W. A. 'I'ownsend \& Co., 1868.

[HERBER'1 (HENRY WM.)] Complete Manual for Young Sportsmen. By Frank Forester. Revised Edition. Illustrated. 12mo. New York: Geo. E. Woodward, (1873).

[HERBER'T (HENRY WM.)] The Newark Herbert Association, to "Frank Forester" in Memoriam, May 19, 1876. 8vo. Newark, N. J.: WARD \& TICHENOR, 1876.

HERBERT (HENRY WM.) Frank Forester's Fugitive Sporting Sketches. By the Late William (sic) Henry Herbert. Edited by Will Wildwood [F. E. Pond]. 12mo. Westfield, Wis.: 1879

[HERBER'T (HENRY WM.)] Frank Forester's Fishermen's Guide. Illustrated. 12mo. New York: Advance Pub. Co., N. D.

[HERBERT (HENRY WM.)] Fishing with Hook and Line. By Frank Forester. Illustrated. 12mo. New York: Peck \& Snxder, N. D.

[HERBER'T (HENRY WM.)] Fishing with Hook and Line. Illustrated. By Frank Forester. 12mo. New York: Thos. O'Kane, N. D.

[HERBERT (HENRY WM.)] Fishing with Hook and Line. Mlustrated. By Frank Forester. 12mo. New York: Hurst \& Co., N. D.

[HERBER'T (HENRY WM.)] Frank Forester's Field Sports. Ornamented Initials. 2 vols. 8vo. New York: Excelsion Publishing House, N. D. 
HERBERT (HENRY WM.) Frank Forester's Fish and Fishing. Illustrated. New Edition. With a Treatise on Fly-Fishing, by "Dinks." 8vo. New York: Excelsior Publishing House, N. D. HERBERT (HENRY WM.) Life and Writings of Frank Forester. Edited by David W. Judd. Illustrated. 2 vols. 12mo. London: F. WARNE \& Co., N. D.

HERRICK (FRANCIS HOBART, PH.D.) The American Lobster: Its Habits and Development. Illustrated. 4to. Washington: 1895. HESSEL (RUDOLPH). The Carp and Its Cultures in Rivers and Lakes. Illustrations. 8vo. Washington: 1880.

HEYRICK (THO.) Miscellany Poems. Sq. 12mo. Cambridge : Printed by John Hayes, for the Author, 1691.

* With a Pindarique Ode in Praise of Angling, etc.

HICKS (J.) Wanderings by the Lochs and Streams of Assynt. Illustrated. 16mo. London: Jas. BlaCkWOod, 1855.

HICKSON (SYDNEY J.) The Fauna of the Deep Sea. 23 Illustrations. 12mo. New York: D. Appleton \& Co., 1894.

HIGHLEY (SAMUEL). Where to Fish Round London. 12mo. London: D. Bogue (1882).

HI-REGAN. ( $p$ seud.) How and Where to Fish in Ireland. Illustrated. 12mo. London: Sampson Low, 1886.

"HI-REGAN." (pseud.) How and Where to Fish in Ireland. Illustrated. Fourth Edition. 12mo. London: SAmpson Low, 1895.

HOFE'S (EDWARD VOM). Illustrated Catalogue of Fine Fishing Tackle. 8vo. New York: 1896.

HOFE'S (EDWARD VOM) Illustrated Catalogue of Fine Fishing Tackle. 8vo. New York: N. D.

HOFLAND ('T. C.) The British Angler's Manual. Engravings on Steel and Wood. First Edition. 12mo. London: Whitehead \& Co., 1839.

HOFLAND (T. C.) The British Angler's Manual. Engravings on Steel and Wood. 8vo. London : Whitenead \& Co., 1839.

* First Edition. Large-paper Copy.

HOFLAND (T. C.) The British Angler's Manual. Engravings on Steel and Wood. 12mo. London: How \& Parsons, 1841.

HOFLAND (T. C.) The British Angler's Manual. Engravings on Steel and Wood. New Edition, Revised and Enlarged by E. Jesse. 12mo. London: H. G. BoнN, 1848. 
HOLBERTON (WAKEMAN). The Art of Angling. Illustrated. 16mo. New York: Dick \& Fitzgerald, (1887).

HOLBERTON (WAKEMAN). The Art of Angling. Illustrated. 8vo. New York: Dick and Fitzghrald, 1887.

* Large-Paper. Only fifty copies printed. No. 4.

HOLBERTON (WAKEMAN). Standard American Flies. Sixty different Flies colored by hand by Wakeman Holberton, from specimens supplied by Abbey and Imbrie, and illustration of a trout. Large folio sheet. New York: 1894.

* Limited to 300 copies, of which this is No. 83. Signed Wakeman Holberton. HOLDER (CHAS. FRED'K.) Along the Florida Reef. Illustrated. Sq. 12mo. New York: D. Appleton \& Co, 1892.

HOLDSWORTH (E. W. H.) Sea Fisheries. Young (Archibald). Salmon Fisheries. 16mo. London: E. Stanford, 1877.

HOLDSWORTH (E. W. H.) Apparatus for Fishing. 8vo. London : Clowes \& Sons, 1883.

HOLLOWAY (WM.) and BRANCH (JOHN). The British Museum; or, Elegant Repository of Natural History. Colored Engravings. 3 vols. 24mo. London: Printed bx J. D. Dewick for John Badoock, 1803-1804.

* Vol. 3. Treats of Fishes and Insects.

HONE (WM.) The Every Day Book. 320 Engravings. First Edition. 2 vols. 8vo. London: Published for WM. Honf, by Hunt \& ClaRKe, 1826-27.

HONE (WM.) The Table Book. 116 Engravings. First Edition. 2 vols. 8vo. London: Published for WM. Hone, BY Hunt \& Crarke, 1827-28.

HOOD'S (THOS.) OWN. First and Second Series. Illustrated. 2 vols. 8vo. London: Edward Moxon \& Co., 1862-1865.

HOPKINS (MAJOl: F. POWELL). Fishing Experiences of Half a Century. Illustrated by the Author. 8vo. London: Longmans, 1893.

HORE (HERBERT FRANCIS). An Inquiry into the Legislation, Control and Improvement of the Salmon and Sea Fisheries of Ireland. 8vo. Dublin: Hodgess \& Sмiтh, 1850.

HORSFALL (J. H.) Letters on Salmon-Ladders. Reprinted from "The Field," with an Introduction. 8vo. Leeds: Yorkshire CoNservative Newspaper Co., 1867.

HOUGHTON (REv. W.) Country Walks of a Naturalist, with His Children. Eight Colored Plates. Second Edition. 12mo. London: Groombridge \& Son, 1870. 
HOUGHTON (Rev. W.) British Fresh-Water Fishes. Tinted and plain Illustrations. 4to. London: H. J. Drane, N. D.

HOUGHTON (Rev. W.) British Fresh-Water Fishes. Colored Plates. Fol. London: (B. Fawcett, Engraver and Printer.) N. D.

HOW TO ANGLE. Including Trolling and Spinning. 24mo. London: B. Blake, Family Herald Office, N. D.

HOW TO HUNT AND FISH. 16mo. New York: Frank Touser, (1882).

HOW TO ANGLE and HOW TO SWIM. Illustrated. 16mo. New York: Popolar Publishing Co., N. D.

HOWES (GEO. BOND). Zoology and Food Fishes. 8vo. London: W. Clowes \& Sons, 1883.

HOWITT (WM.) The Book of the Seasons. Illustrated. $16 \mathrm{mo}$. London: H. Colburn and R. Beitrtey, 1831.

HOWITT (WM.) The Book of the Seasons. Illustrated. Fourth Edition. 16mo. London: R. Bentley, 1836.

HOWITT (WM.) The Rural Life of England, Illustrated. 2 vols. 12mo. London: Longman, 1838.

HOWITT (WM.) The Book of the Seasons. Illustrated. Sixth Edition. 16mo. London: R. Bentley, 1840.

HOWITT (WM.) The Rural Life of England. From the Second London Edition. Front. 8vo. Phila.: CAREY \& HART, 1841.

HOWITT (WM.) The Book of the Seasons. From the Sixth London Edition. 12mo. Philadelphia: Carey \& Hart, 1842.

HOWITT (WM.) The Year Book of the Country. Illustrated. $18 \mathrm{mo.}$ London: H. Colburn, 1850.

HOWITT (MARY, Editor). Pictorial Calendar of the Seasons. 100 Engravings. 12mo. London: H. G. ВонN, 1854.

HUBBARD (BELA). Memorials of a Half Century. Illustrated. Sq. 12mo. New York and London: G. P. Putnam's Sons, 1887.

HUBBARD (LUCIUS L.) Summer Vacations at Moosehead Lake and Vicinity. Maps and Photo Illustrations. 24mo. Boston: A. Wrlliams \& Co., 1879.

HUBBARD (LUCIUS L.) Guide to Moosehead Lake and Northern Maine. Illustrated with Maps, etc. 24mo. Boston: A. Williams \& Co., 1882.

HUBBARD (LUCIUS L.) Woods and Lakes of Maine. Illustrations by W. L. I'aylor. Second Edition. Sq. 8vo. Boston: Traknor \& Co., (1888). 
Ollinois. Rept of the State Zish Com.x July 1 to Sept 30. 
[HUGHES (W.)] The Practical Angler. By Piscator. (pseud.) Steel Engravings. 8vo. London: Simpkin, Marshall \& Co., $18+2$.

[HUGHES (W.)] Fish: How to Choose and How to Dress. By Piscator. (pseud.) 16mo. London: Longman, 1843.

[HUGHES (W.)] A Practical Treatise on the Choice and Cookery of Fish. By Piscator. (pseud.) Second Edition. 16mo. London: LoNGMaN, 1854.

HUISH (ROBERT). The Improved British Angler, containing the most Improved Methods of Angling for Pond and River Fish. Colored Frontispiece and other Illustrations. 24mo. Derby: THos. Richardson, 1838.

HULBERT (CHAS.) Museum Americanum; or, Select Antiquities, Curiosities, Beauties, and Varieties of Nature and Art. Illustrated. 16mo. London: G. \& W. B. Whittaker, 1823.

HULME (F. EDWARD). Natural History, Love and Legend. Illustrated. 12mo. London: B. QUaRITCH, 1895.

HUMPHREYS (H. NOEL.) River Gardens. Colored Plates. Sq. 12mo. London: SAMpson Low, 1857.

HUMPHREYS (H. NOEL.) Ocean Gardens. Colored Plates. Sq. 12mo. London: SAMPson Low, 1857.

HUNTER AND ANGLER. Illustrated. 16mo. New York: Champion Publishing Co., 1882.

HUNTER AND ANGLER. Illustrated. 12mo. New York: STREeT \& SMтTH, N. D.

HUNTERS' AND TRAPPERS' COMPLETE GUIDE. Illustrated. By an Old Hunter and Trapper. 12mo. New York: Hurst \& Co., 1875.

HUNTING AND SPORTING. Practical Lessons on. By Scrutator. 12mo. London: Chapman \& Hall, 1865.

DLE (CHRISTOP HER). ( pseud.) Hints on Shooting and Fishing, etc. 16mo. London: Longman, 1855.

IDLE (CHRIS'TOPHER). ( sseud.) Hints on Shooting and Fishing, ete. Second Edition. 16mo. London: Longmans, 1868.

ILLINOIS (S'TATE OF). Report State Fish Commissioners, Sept. 30, 1884. 8vo. Springfield: 1884 .

ILLINOIS. Report of State Fish Commissioners, Sept. 30, 1886. 8 ro. Springfield : 1887.

ILLINOIS. Report of State Fish Commissioners, Sept. 30, 1888. 8 vo. Springfield : 1889. 
ILLUSTRATED CATALOGUE and Price List of fine Fishing Tackle, Manufactured by Abbey \& Imbrie. Oblong 8vo. New York: C. F. IMBRIE, 1884.

INDIANA (STA'TE OF). First Annual Report of the Commissioners of Fisheries of Indiana. 8vo. Indianapolis: 1883.

INGERSOLL (ERNEST). Nature's Calendar. Illustrated. Sq. 8vo. New York and London: HARPERs, 1900.

INTELLECTUAL OBSERVER. Articles on Fish, Fishing, etc., from Vols. 1-12 of the Intellectual Observer. Illustrated. 8vo. London: 1862-68.

INTEREST (THE) OF SCO'TLAND CONSIDERED. Vignette and Coat of Arms. 12mo. Edinburgh: Printed by R. Fleming \& Co., 1733.

* Relates to Fisheries, etc.

INTERNATIONAL ASSOCIATION FOR PROTECTING GAME AND FISH. Report of Chas. Hallock, Sec'ty. 8vo. New York: 1876.

INTERNATIONAI, FISHERIES EXHIBITION. London, 1883. Many Illustrations. 14 vols. 8vo. London: WM. Clowes \& Sons, 1882-1884.

* A vast amount of information given in these vols., including official catalogues, etc.

IOW A (STATE OF). Second Biennial Report of the State Fish Commissioner of Iowa, Years 1875-6 and 1876-7. 8vo. Des Moines: 1877.

IOWA. Fifth Annual Report of the State Fish Commissioner of Iowa. 1881-2 and 1882-3. 8vo. Des Moines: 1883.

IOWA. Sixth Biennial Report, State Fish Commissioner of Iowa, Years 1883-84 and 1884-85. 8vo. Des Moines: 1885.

[IRELAND (S. W. H.)] The Fisher Boy. A Poem. By. H. C. Engravings. 16mo. London: Printed For Vernor, Hood \& Sharpe, 1808.

[IRVING (WASHINGTON).]. The Sketch Book of Geoffrey Crayon, Gent. No. VII. Containing the Article "The Angler." First Edition. 8vo. New York: C. S. Van Winkle, 1820.

[IRVING (WASHINGTON).] The Sketch Book of Geoffrey Crayon, Gent. Seven parts of the Original Edition. With inserted plates. 7 vols. 8vo. New York: Printed by C. S. VAN WINkLe, No. 101 Greenwion ST., 1819-1820.

"The seventh part contains " The Angler." 
$2+2+2$ 
[IRVING (WASHINGTON).] The Sketch Book of Geoffrey Crayon, Gent. 2 vols. 8vo. London: JoHn Miller, 1820. (2d vol. JoHN MURrAy, 1820.)

[IRVING (WASHINGTON).] The Sketch Book of Geoffrey Crayon, Gent. New Edition. 2 vols. 16mo. London: John Murray, 1826.

[IRVING (WASHINGTON).] The Sketch Book. With Heath's Illustrations. Seventh American Edition. 2 vols. 16mo. Phila.: Carey and Lea, 1831.

[IRVING (WASHINGTON).] The Sketch Book of Geoffrey Crayon, Gent. 2 vols. 12mo. Phila.: Carex and Lea, 1835.

[IRVING (WASHING'TON).] The Sketch Buok of Geoffrey Crayon, Gent. Authors revised Edition. With Original Designs by F. O. C. Darley. Sq. 8vo. New York: G. P. Putnam, 1849.

IRVING (WASHINGTON). Sketch Book of Geoffrey Crayon, Gent. Cabinet Edition. Illustrated. Sq. 8vo. Phila.: J. B. Lippincotr Co., N. D. (1875).

[IRVING (W ASHING'TON).] Sketch Book of Geoffrey Crayon, Gent. Edition de Luxe. With all the Illustrations, proofs on India Paper. 4to. Philadelphia: J. B. Lippincotr Co., 1882.

* 500 copies printed. This No. 392.

IRVING (WASHINGTON). The Angler. With Etched Illustrations, by Louis K. Harlow. Sq. 16mo. Boston: S. E. Cassino, 1892.

[IRVING (WASHING'TON).] Sketch Book of Geoffrey Crayon, Gent. Illustrated. 2 vols. 8vo. Phila: J. B. Lippincotr Co., 1894.

[IRVING (W ASHING'ION).] The Sketch Book of Geoffrey Crayon, Gent. The Author's Revised Edition Complete in one vol. $16 \mathrm{mo}$. New York: G. P. Putnam's Sons, N. D.

ISYS (CO'TSWOLD). An Angler's Strange Expericnces. Illustrated. Sq. 8vo. London: Sampson Low, 1883.

ISYS (COTSWOLD). A Handy Guide to Dry-Fly lishing. 2 Illustrations. Third Edition. 12mo. London: Sampson Low, 1894.

ISYS (COTSWOLD). Lyra Piscatoria. 16mo. London: H. Cox, 1895.

ACKSON (JOHN). The Practical Fly-Fisher. Colored Plates. Third Edition. 8vo. London and Leeds: 1880.

JACKSON (JOHN). The Practical Fly-Fisher. Colored Plates. Fourth Edition. 8vo. London: Grbbings \& Co., 1899. 
JACKSON (R. M. S.) The Mountain. 12mo. Philadelphia: J. B. Lippincott Co., 1860.

JACOB (GILES). The Compleat Sportsman. 16mo. In the Savoy: Printed by Eliz. Nutt and R. Gossing, 1718.

JAFFIER (J.) Eléments de Pisciculture Pratique. 50 Engravings. 12mo. Paris: A. Courn \& Cie., 1897.

JANNETTAZ (ED.) Les Poissons. Organization-DescriptionFamile - Ordre-Groupe - Pisciculture. New Edition. $16 \mathrm{mo}$. Paris: N. D.

JARDINE (Sir WM.) Natural History of Fishes of the Perch Family. 36 Colored Plates. First Edition. 16mo. Edinburgh: W. H. Lizars, 1835.

[JEFFERIES (RICHARD)]. The Amateur Poacher. 12mo. Boston: RoBer'ss Bros., 1879.

JEFFERIES (RICHARD). The Gamekeeper At Home. Third Edition. 12mo. Boston: Roberts Bros., 1879.

JEFFERIES (RICHARD). Wild Life in a Southern Country. Vignette on title. 16mo. Boston: Roberts Bros., 1879.

(JEFFONHAM). Tales Told to Anglers. Printer's proof mounted and bound. $16 \mathrm{mo}$. N. P., N. D.

JENNESS (JOHN SCRIBNER). The Isles of Shoals. Map and Illustrations. 16mo. New York: Hurd \& Houghton, 1873.

JESSE (CAPtaIN). Le Morvan (a district of France). Its Wild Sports, Vineyards and Forests. By Henri de Crignelle. Translated. Frontispiece. 12mo. (London) Saunders \& Otley, 1851.

JESSE (EDWARD). Gleanings in Natural History. Illustrated. First Edition. 12mo. London : John Murray, 1832.

JESSE (EDWARD). Gleanings in Natural History. To which are added Maxims and Hints for an Angler. 16mo. Phila.: $\mathrm{C}_{\triangle \mathrm{REY}}$, Lea \& Blanchard, 1833.

JESSE (EDWARD). Gleanings in Natural History. Second Series. Illustrations and facsimile. 'First Edition. 12mo. London: JoHN MURRAY, 1834.

JESSE (EDWARD). Gleanings in Natural History. Illustrated. Third and Last Series. First Edition. 12mo. London: JoHN MURRAY, 1835.

JESSE (EDWARD). An Angler's Rambles. First Edition. $12 \mathrm{mo}$. London: J. VAN Voorst, 1836. 



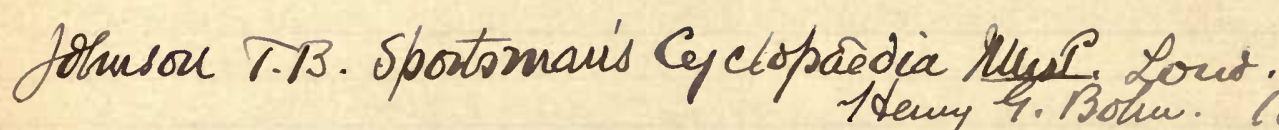
Atany Y. Bolver. 1848

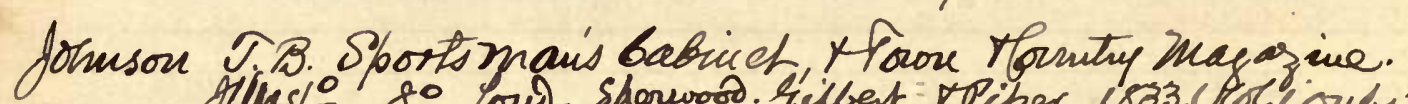

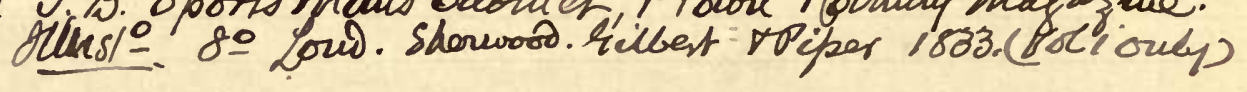
Iones, Rev C.A. Home Walls YHoliday Rambles. Heus? $12^{\circ}$ Cloth Roudon: Lougmant May (ARas) Gones, G. B. Wild Westène scesues new Ehn Rlêted, revised rected. 16 Eugp. 120 Phila: HPh ippincent to, 1857 
JESSE (EDWARD). Scenes and Tales of Conntry Life. Woodcuts. First Edition. 8vo. London: John Murray, 1844.

JESSE (EDWARD). Scenes and Occupations of Country Life. Woodcuts. New and Revised Edition. 16mo. London: John Murray, 1853.

JESSE (EDWARD). Lectures on Natural History. Reprinted from The Brighton Herald. 8vo. London and Brighton: 1860.

JOHN (UNCLE). Boy's Book of Sports and Games. Illustrated. Sq. 24mo. Phila.: Geo. S. Appleton, 1851.

JOHN (UNCLE). The Boy's Own Book. Illustrated. 12mo. New York: Hors' \& Co., N. D.

JOHNS (Rev. C. A.) Home Walks and Holiday Rambles. Illustrated. 12mo. London: Longmans, (1863).

JOHNSON (T. B.) The Sportsman's Cyclopedia. Portrait and Illustrations. 8vo. London: Sherwood, Gilbert \& Piper, 1831.

JOHNSON (T. B.) Sportsmen's Cabinet, Town and Country Magazine, from Nov., 1832, to Oct., 1833. 2 vols. 8vo. London: 1832-33.

* Signature A missing from Vol. 1.

JOHONNOT (JAMES). A Natural History Reader for School and Home. Illustrated. 16mo. New York: Appleton, 1883.

JONES'S (J.) Guide to Norway. Edited by Frederick Tolfrey. Colored Plates. 16mo. London: Longmans, 1848.

JONES (J. B.) Rural Sports. A Tale. 12mo. Phila.: Chas.Marshall, 1849.

JONES (J. W. C.) The Water World. Illustrated. 8vo. Chicago: Aome Publishing House Co., 1889.

* Sold only by Subscription.

JONES (WM.) The Broad, Broad Ocean. A New Edition. With illustrations. 12mo. London: F. WARNE \& Co., N. D.

JOIGNEAUX (P.) Pisciculture et Culture des Eaux. Illustrated. 12mo Paris: N. D.

JORDAN (Prof. DAVID S.) Fishes of Indiana. Reprinted from The Geological Survey. Frront. 8vo. N. P.: 1874.

* Relates to the "Sisco of Lake Tippecanoe and Its Relatives."

JORDAN (Prof. D. S.) and Van Vleck (B. H.) A Popular Key to the Birds, Reptiles, Batrachians and Fishes of the Northern U. S. East of the Miss. Sq. 24mo. (N. Y.) Appleton, 1874.

JORDAN (D. S.) On the Distribution of the Fresh-Water Fishes of the United States. 8vo. Indianapolis: 1876. 
JORDAN (D. S.) and Brayton (A. W.) Contributions to North American Ichthyology. Based Primarily on the Collections of the United States National Museum. 8vo. Washington : 1878.

JORDAN (D. S.) Report on the Collection of Fishes made by Dr. Elliott Coues, U. S. A., in Dakota and Montana, 1873-1874. 8vo. Washington: Dec. 11, 1878.

JORDAN (D. S.) Science Sketches. 12mo. Chicago: A. C. McClura \& Co., 1888.

JORDAN (D. S.) and Copeland (H. E.) Check List of the Fishes of the Fresh Waters of North America. 8vo. N. P., N. D.

* From the Bulletin of the Buffalo Society of Natural Sciences.

JOURDEUIL (E.) La Traite son Histoire ses Habitudes, ses Differénts Modes de Pêche. 16mo. Dijon: 1872.

JOURDEUIL (E.) La Pêche du Dimanche. 16mo. Paris: N. D.

JOVII (PAVLI). Novocomensis, de Piscibvs Marinis Lacrstribvs, item de Testaceisac Salsamentis Liber. [Colophon] Romae Ex AEdibvs F. Minitii Calvi, Anno MDXXVII. Meuse Aprili Pontificatvs. S. D. N. Clementis. VII. Pont. Max. Anno IIII. 12mo. Woodcut border round title.

JUDKIN (REv. T. J.) Bygone Moods. Illustrated. 12mo. London : LoNGMANs, 1856.

TARR (ALPHONSE). Dictionnaire du Pêcheur. Traite Comple de la Pêche en eau Douce et en eau Salee. Histoire des Poissons etc. 16mo. Paris: 1855.

KARR (ALPHONSE). La Pêche en eau Douce et en eau Salee, etc. Second Edition. 12mo. Paris : 1860.

KEENE (J. H.) The Practical Fisherman. Illustrated. 12mo. London: "The Bazaar" Offich, 1881.

KEENE (JOHN HARRINGTON.) Fishing Tackle. Its Material and Manufacture. 254 Illustrations. 12mo. London: WARD, LooK \& Co., (1886.)

KEENE (J. H.) Fly-Fishing and Fly-Making for Trout, etc. With plates of actual material and other illustrations. $12 \mathrm{mo}$. New York: 0 . JoDD \& Co., 1887.

KEENE (J. H.) The Boy's Own Guide to Fishing. Illustrated. $12 \mathrm{mo.}$ Boston: Lee \& Shepard, (1894).

KELLOGG (ELIJAH). The Fisher Boys of Pleasant Cove. Illustrated. 12mo. Boston: Lee \& Shepard, 1890. 
Gordan (Prof D.S.) HGatalogue of the Tishes Nwown to hehabih the watero of X.a. Worth of the Tropie o Caucor 80 Mashinfor 1885 


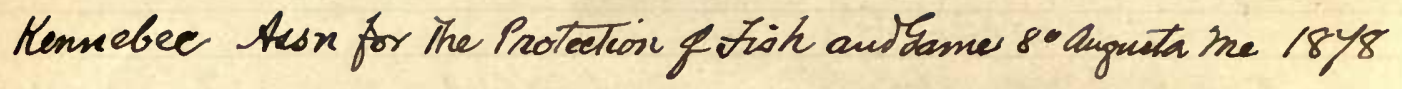

Hinigsley (bhas.) The Water-Babies Mcco El ifore 100 Mewh

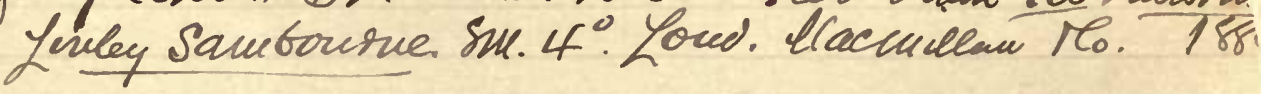


KEMP (JOHN). Shooting and Fishing in Lower Brittany. Map. $12 \mathrm{mo}$. London : LoNGMAN, 1859.

KENDALL (SIDNEY C.) Among the Laurentians. 12mo. Toronto: WM. BRIGGS, 1885.

KENNARD (EDWARD). Norwegian Sketches. Fishing in Strange Waters. Illustrations printed by the Automatic Engraving Co. Oblong 4to. London: Chapman \& Hall, 1889.

KENNARD (EDWARD). Norwegian Sketches. Fishing in Strange Waters. Finely Illugtrated. 8vo. London and Norway: 1889. KENNARD (Mrs. EDWARD). Landing a Prize. (Pictured Cover bound in.) 16mo. London: F. V. Write \& Co., 1891.

[KENNEDY (J. P.)] The Blackwater Chronicle. A Narrative of an Expedition Into the Land of Canaan in Randolph Co., Virginia. By "The Clerke of Oxenforde." Illustrated. First Edition. $12 \mathrm{mo}$. New York: Redfigld, 1853.

KENNEDY (САPт. W. R.) Sport, Travel and Adventure in Newfoundland and the West Indies. Illustrations. 12mo. Edin. and London: BLAOKWOOD, 1885.

KENT (W. SAVILLE). Hand-Book of the Marine and Fresh Water Fishes of the British Islands. Illustrated. 8vo. London: WM. Clowes \& Sons, 1883.

KILBOURNE (S. A.) Game Fishes of the United States. Text by G. Brown Goode. Large 4to parts in Portfolio-Complete. 20 colored figures of Fish. New York: Soribners, N. D.

KING (JOHN LYLE). Trouting on the Brale River. Map. $12 \mathrm{mo.}$ Chicago: Chic. Legal News Co., 1879.

KING (JOHN LYLE). Trouting on the Brule River. Map. $12 \mathrm{mo}$. New York: Orange Jund Co., 1880.

KING (MaJ. IV. ROSS). The Sportsman and Naturalist in Canada. Colored Plates and Woodcuts. 4to. London: HuRst \& Blackett, 1866.

KINGSLEY (CHAS.) Glaucus; or, the Wonders of the Shore. Third Edition. Colored Illustrations. 16mo. Cambridge: Macmillan, 1858.

KINGSLEY (Rev. CHAS.) Prose Idylls, New and Old. Second Edition. 12mo. London: Macmillan, 1874.

KINGSLEY (CHARLES). His Letters and Memory of His Life. Edited by His Wife. Abridged from the London Edition. Portrait. 12mo. New York: Chas. Soribner's Sons, 1884. 
KINGSLEY (GEO. HENRY). Notes on Sport and Travel. Memoir by His Daughter. Portrait. 8vo. London: Macminlan, 1900.

KIPLING (RUDYARD). "Captains Courageous." A Story of the Grand Banks. Illustrated. 12mo. London: Macmillan, 1897.

KIRKBRIDE(JOHN). The Northern Angler; or, Ex-Fisher's Companion. Steel Front. and Woodcut. 16mo. Carlisle: C. Thurman, 1837 .

KLEIN (JACOBI THEO.) Historiæ Piscium Naturalis Promovendæ. Missus Primus de Lapillis Eorvmque Numero in Cranis Piscium, etc. 54 Fine Plates (1 inserted), 5 parts in 1 vol., 4to. Editio Secondo. Lipsiæ, in Libraria Gleditsohia, 1802.

KNIGH'T (CHAS.) A Volume of Varieties. By the Editor of the Weekly Volume. 24mo. London: Chas. Kniant \& Co., 1844.

KNOBEL (EDWARD). The Fresh Water Fishes of New England. Illustrated. Oblong 24mo. Boston: BradLEE WHIDDEN, (1896).

KNOX(Dr.) Fish and Fishing in the Lone Glens of Scotland. Illustrated. 12mo. London: Routledge, 1854.

KNOX (A. E.) Autumns on the Spey. 4 Illustrations, Tinted. $12 \mathrm{mo.}$ London: J. VAN Voorst, 1872.

KOLTZ (M. J. P. J.) Traite de Pisciculture Pratique ou des Procédés de Multiplication et D'Incubation Naturelle et Artificielle. Troisiéme Edition. Illustrated. 16mo. Paris: 1866.

KRESZ (C.) Le Pêcheur Francais, Traite de la Pêche a la Ligne en Eau Douce. Denxiéme Edition. Portrait and Plates. 16mo. Paris: 1830 .

(F.) A Treatise on the Art of Taking Pike, Perch, Chub, etc., with the Trimmer. By F. L. A. Sussex, Fisherman. Sq. 8vo. London, \&c., N. D.

* This is in manuscript, on 23 Sq. 8vo pages, written very neatly on one side of leaf only with two original water color drawings.

LABRADOR. Salmon Angling in the Streams of the Far North. Season 1901. Narrow 12mo. Montreal: Str. Lawrence Steamship Co., 1901.

LADY. The Accomplished Lady's Delight. (Part VI. The Female Angler.) Eleventh Edition. 24mo. London: Printed For John [ ] and Joseph Baddington, N. D. (1720.)

* Name of first printer missing.

LAINC (SAMUEL). Journal of a Residence is: Norway, during the years 1834, 1835, and 1836. Second Edition. 8vo. London: LongMAN, 1837. 

LAKELAND (R.) The Teesdale Angler. 16mo. Barnard Castle: R. $/ / A R /$ BARKLR, 1858.

LAKE SIDE LIBRARY. Fish and Fishing. By Thos. Alexander. Illustrated. Folio. Chicago: Donneluy, Loyd \& Co., 1877.

LAMBERT (M.) Nouveau Manuel Complet du Pêcheur-Praticien. New Edition. 2 folded and other illustrations. 24mo. Paris: De RoRET, 1870.

LAMBERT(OSMUND). Angling Literature in England. 16mo. London: SAMPson Low, 1881.

LAMONT (JAS.) Seasons with the Sea-Horses. Map and Illustrations. 8vo. New York: Harpers, 1861.

LAMY (ISIDORE). Nouveaux Eléments de Pisciculture. Second Edition. 12mo. Paris and Chartres : 1866.

LANG (ANDREW). Grass of Parnassus. Rhymes Old and New. 8vo. London : Longmans, 1888.

* Large Paper.

LANG (ANDREW). Lost Leaders. 8vo. London: KEgaN PAUL, 1889. *Large-paper copy. No. 63 of 100 printed.

LANG (ANDREW). Old Friends. Essays in Epistolary Parody. 8vo. London: Longmans, 1890.

* Large-paper copy. Printed on Japan paper of which only 150 were done. No. 49.

LANG (ANDREW). Angling Sketches. Three Etchings and Numerous Illustrations. 4to. London: Longmans, 1891.

* Large-paper copy. 150 copies printed. No. 10.

LANG (ANDREW). Angling Sketches with 3 Etchings and other Illustrations. 12mo. London : Longmans, 1891.

LANG (ANDREW). Letters to Dead Authors. Etched Portrait and four additional letters. 8vo. New York: Chas. Scribnim's Sons, 1893.

LANG (ANDREW). The Tercentenary of Izaak Walton. Illustrated. 4to. London : Printed for Private Circulation only, 1893.

* Limited to a few Impressions.

LANMAN (CHAS.) Essays for Summer Hours. 12mo. Boston: HrLLIARD, GRAX \& Co., 1841.

LANMAN (CHAS.) Essays for Summer Hours. Second Edition with a Frontispiece. 12mo. Boston and London : 1842.

[LANMAN (CHAS.)] Letters from a Landscape Painter. $16 \mathrm{mo.}$ Boston: Jas. Monroe \& Co., 1845. 
LANMAN (CHAS.) A Summer in the Wilderness. 12mo. New York and Phila.: 1847.

LANMAN (CHAS.) Adventures of an Angler in Canada. Portrait and Illustrations. 12mo. London: R. Benteex, 1848.

LANMAN (CHAS.) A Tour to the River Saguenay. 12mo. Phila.: Caret \& Hart, 1848.

LANMAN (CHAS.) Letters from the Alleghany Mountains. $12 \mathrm{mo.}$ New York: G. P. Putnam, 1849.

LANMAN (CHAS.) Haw-Ho-Noo ; or, Records of a Tourist. $12 \mathrm{mo.}$ Phila.: Lippincott, Grambo \& Co., 1850.

LANMAN (CHAS.) Adventures in the Wilds of North America. Edited by C. R. Weld, 2 parts. 12 mo. London : Longmans, 1854.

LANMAN (CHAS.) Adrentures in the Wilds of the United States and British American Provinces. Illustrated. 2 vols. 8vo. Phil.: J. W. Moore, 1856.

LANMAN (CHAS.) The Red Book of Michigan. 8vo. Detroit and Washington: 1871.

LANMAN (CHAS.) Recollections of Curions Characters and Pleasant Places. Front. 8vo. Edin.: D. Douglas, 1881.

LARBALETRIER (ALBERT). Traite-Manuel de Pisciculture D'Eau Douce. 64 Illustrations. Deuxiéme Edition. 12mo. Paris : 1886.

[LASCELLES (ROBERT).] Angling (being the first part of a series of Familiar Letters on Sporting), signed Piscator. Frontispiece. 8vo. London: W. Wilson, Printer, (1818).

* Dated London, Feb., 1811. This is the Second Edition. See imprint at endfor change in name of Printer.

[LA'THY (THOS. PIKE).] The Angler. A Poem by Piscator. Portrait and Vignettes. First Edition. 16mo. London: W. WrianT \& M. ILEY, 1819.

LATHY (T. P.) The Angler; A Poem. Portrait and Vignettes. Second Edition. 16mo. London: J. H. BurN, 1820.

LATHY, (T. P.) The Angler; A Poem. Portrait and 20 Woodcuts. Third Edition. 12mo. London: Sherwood, Neely \& Jones, 1822.

LATHY ('T. P.) The Angler; A Poem. Portrait and Woodcuts. 16mo. London : Sherwood, Gilbert \& Piper, 1841.

[LA TOURETTE (GUY SEGUINE)]. A North Jersey Jaunt. $16 \mathrm{mo}$. [New York: J. W. Pratt, 1874, or 1875.] 
Lees, 8.a. xClutterbuck. W.9. B.C. 188\%. ARaunble in Britiót Colmubicl. Maprys situstus. 12\%. Lond. Longmans. 1888.

Le Moine, I.M. Maple Laares, 8. Zuebec, For the Coutier 1863

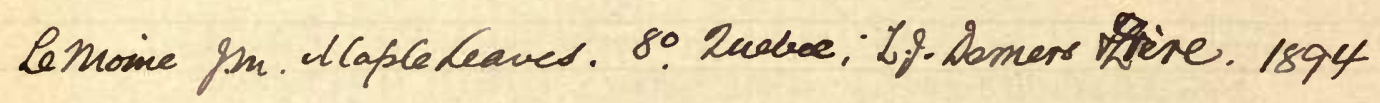
Remoine fim. The fegends of The Mr. Lawrance. So Lecebes "LeSoleil" 1898

- Lempriere, Mm ATour fim Gibralta to Taugiò ve. So Lowo Printed for the auttios. 179 
LA VIE A LA CAMPAGNE. Chasse, Péche, Courses, Haras, Nouvelles, Beaux-Arts, etc. Pisciculture Regates, etc. Illustrated with Etchings, etc., of Fish, some beautifully colored. 11 vols. Roy. 8vo. Paris : 1861-1867.

LEE (Mrs. R.) Anecdotes of the Habits and Instincts of Birds, Reptiles and Fishes. Illustrated. 16mo. London: Grant \& Grifrith, 1853.

LEFFINGWELL (WM. BRUCE). Hunting and Fishing Along the North-Western Line. Illustrated by W. L. Wells. 8vo. Chicago: RAND, MoNaLlY \& Co., 1895.

LEHIGH VALLEY R. R. Hunting and Fishing. Illustrated. Narrow 8vo. Philadelphia: N. D.

LE MOINE (J. M.) Maple Leaves. Second Series. 8vo. Quebec: For the AUthor, 1864.

LE MOINE (J. M.) Maple Leaves. New Series. 8vo. Quebec: A UGUSTIN Coté \& Co., 1873.

LE MOINE (J. M.) The Explorations of Jonathan Oldbuck in Eastern Latitudes. 8vo. Quebec: L. J. Demers \& Frìre, 1889.

LENNOX (LORD WM.) Merrie England: Its Sports and Pastimes. 8vo. London: T. C. NewBr, 1857.

LENNOX (LORD WM.) Recreations of a Sportsman. 2 Frontispieces. 2 vols. 12mo. London: Hurst \& Blackett, 1862.

LENNOX (LORD WM. PITT). Sport at Home and Abroad. 2 vols. 12mo. London: Hurst \& BLACKETT, 1872.

LEREBOULLET (A.) Recherches D'Embryologie Comparée sur le Développement de la Truite, du Lezard et du Limnée. Illustrations. 4to. Paris: 1863.

LES RUSES INNOCENTES DE LAA CHASSE ET DE LA PESCHE. A vec Les Plus Beaux secrets de la Pêche dans les Rivieres et dans les Etangs. Illustrated. 16mo. Amsterdam: Chez Daniel DE LA FUEILLE, 1695.

LEVINE (Captain R. G. A.) Echoes from the Backwoods. Illustrated. 2 vols. 12mo. London: H. Colbura, 1846.

LEWES (GEO. HENRY). Sea-Side Studies. Illustrated. 8vo. Edin. and London: W. Blackwood \& Sons, 1858.

LEYLAND (JOHN). The Yorkshire Coast. Illustrated. 8vo. London: Srember \& Co., 1892.

* Large Paper. 250 printed. No. 198.

LIDDLE (HoN. and REv. ROBT.) The Lay of the Last Angler. Illustrated. 12mo. Kelso: J. \& J. H. RUTHERFURD, 1884. 
LIGER (SIEUR). La Nouvelle Maison Rustique ou Economie Generale. Onzieme Edition. Engravings. 2 vols. 4to. Paris : Chez Desaint, 1777.

LITTLE'S (G.) Anglers' Annual. Illustrated. Sq. 8vo. London : G. Litrtle \& WM. Cate, (1882).

LITTLE'S (G.) Anglers' Annual and Fishing Directory. Edited by H. B. Bromhead. 8vo. London: G. Little \& Co., 1883.

LITTLE'S (G.) Anglers' Annual and Directory. Edited by H. B. Bromhead. 8vo. London: G. Lrtrue \& Co., 1885.

LITTLE (G.) The Anglers' Complete Guide and Companion. Illustrated. 12mo. London: By тне A चтнов, N. D.

LIVERMORE (REv. S. T.) A History of Block Island. First Edition. 12mo. Hartford: Case, Lockwood \& Brainard Co., 1877.

LIVINGSTONE (DAVID). Missionary Travels and Researches in South Africa. Illustrated. 8vo. N. Y.: 1858.

LLOYD (L.) Field Sports of the North of Europe. Illustrated. Second Edition. 2 vols. 8vo. London : H. ColbuRn \& R. Bentler, 1831.

LLUELLIN (M., Student of Ch. Ch. in Oxon.) Men-Miracles. With other Poems. 24mo. London : Printed, \& are to be sold by Peter PARKer, 1679.

* "Song Against Fishing," pp. 53-54.

LOCARD (ARNOLD). La Pêche et les Poissons des Eaux Douces. Avec Figures intercalees dans le texte. 16mo. Paris: 1891.

LOCH. By the Loch and River Side. Thirty-nine Lithographic Plates depicting Fishing. Signed with Initials K. J. F. Oblong 4to. Edin. burgh : Edmonston \& Douglas, 1866.

[LOCKE (JAS.)] Tweed and Don. Front. 16mo. Edin. and London : W. P. Nimmo, 1860.

[LOCKE (JAS.)] Tweed and Don. Front. Second Edition. $16 \mathrm{mo}$. Edin. and London : 1860.

LOCKWOOD (EDWARD). Natural History, Sport and Travel. Illustrated. 12mo. W. H. Allen \& Co., 1878.

LONDON (The) Fishery Laid Open. Sq. 8vo. London: Printed BY D. HENRy AND R. CAVE, 1759.

LONDON ALMANACK. 1864. Illustrated with colored and plain Engravings. 4to. London: Illustrated London News OfFioe, (1864).

LONSDALE'S (LORD). Salmon Hall Fishery. Map of River Derwent. 8vo. London: G. E. Eyre \& W. Spotriswood, 1868. 


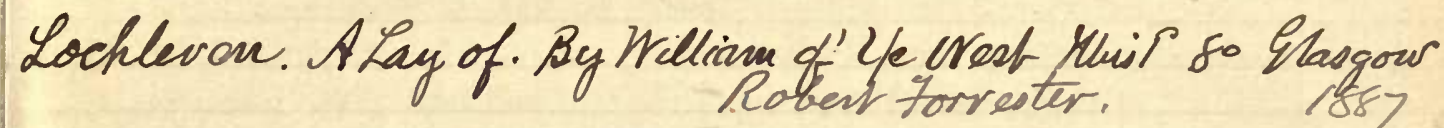

1857

aoc 


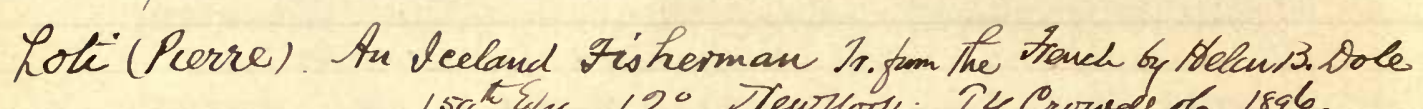
$159^{\circ}$ \&inc. $12^{\circ}$. Tew fork: T.Y. Crowde 16. 1896.

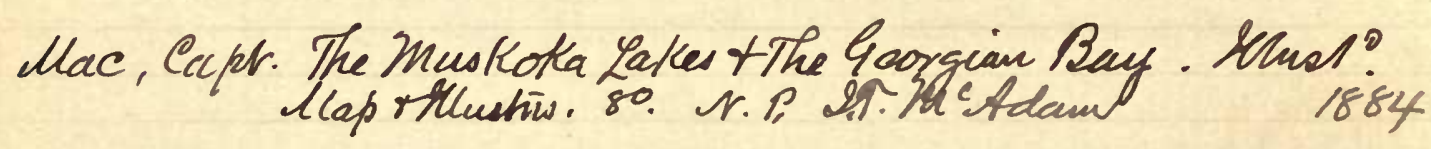


LORD (JOHN KEAST). The Naturalist in Vancouver Island and British Columbia. Illustrated. 2 vols. 8vo. London: R. Bentlex, 1866.

LORD (JOHN KEAST). At Home in the Wilderness. By "The Wanderer." Illustrated. 12mo. London: R. HARDwICKE, 1867.

LORD (W. B.) Sea Fish and How to Catch Them. Illustrated. $16 \mathrm{mo}$. London : Bradbery, Agnew \& Co., N. D.

LORD (W. B., R.A.) Sea Fish and How to Catch Them. Illustrated. Second Edition. 16mo. London : Bradberry \& Evans, N. D.

LOUGH FOYLE FISHERY CASE REPORT. 8vo. London: Arthur Taylor, 1857.

LOVELL (M. S.) Edible Mollusks. Colored Plates. 12mo. London: REEVE \& Co., 1867.

LOWSON (G.) The Modern Farrier: Sporting and Fishing, etc. Engravings. 8vo. London: Jones \& Co., N. D.

LOWTH (W. S.) Angling, Angling Dodges and Match Fishing. 8vo. Newport, Hull: W. S. Lowrh, (1860).

LUBBOCK (REv. RICHARD). Observations on the Fauna of Norfolk. Map. 8vo. Norwich : Chas. Muskett, 1845.

M

ACKAY (CHAS.) The Thames and Its Tributaries. Illustrated. 2 vols. 8vo. London: R. Bentley, 1840.

MACKENZIE (ALEXANDER). Voyages from Montreal, on the River St. Lawrence, etc. Portrait and Maps. 2 vols. 12mo. London: T. Cadell \& W. Adams, etc., 1802.

MACKENZIE (MURDO). View of the Salmon Fishery of Scotland. 8vo. Edin. and London: W. Blackwood \& Sons, 1860.

MACKINTOSH (ALEXANDER). The Driffield Angler. Portrait. 16mo. Gainsborough: For the Author, (1806).

MACKIN'TOSH (ALEXANDER). The Modern Fisher; or, Driffield Angler. Second Edition. 16mo. Derby: Henry Mozlex, N. D.

MACKINTOSH (ALEXANDER). The Modern Fisher; or, Driffield Angler. Front. and Vig. Third Edition. 16mo. Derby: HeNRY Mozlex, 1821.

MACLOC (J.) New, Complete and Universal Natural History. From the last London Edition of J. Macloc. 57 Copper Plates. $16 \mathrm{mo}$. Phila.: J. Pounder, 1821.

MAC VINE (JOHN). Sixty-Three Years' Angling. 12mo. London : LoNGMaNs, 1891. 
MACY (OBED). History of Nuntucket, The Whale Fishery, etc. Plate. 12mo. Boston: Hilliard, Gray \& Co., 1835.

MACY (OBED). History of Nantucket. Map and Plate. Second Edition. 12mo. Mansfield: Macy \& Pratt, 1880.

MACY (CAptN. W. H.) There She Blows! or, The Log of the Arethusa. Illustrated. 16mo. Boston : Lee \& Shepard. N. Y.: C. F. DiluingнАМ, 1877.

MAGAZINE TROUT STORIES. (List of Contents in each volume.) 3 vols. 8vo. N. P.: 1896, 1897, 1898.

MAGAZINE FISH STORIES. Vol. IV. 8vo. 1900.

MAGRATH (T. W.) Authentic Letters from Upper Canada. Edited by Rev. T. Radcliff. Etchings by Samuel Lover. 12mo. Dublin: Wм. Corry, Jr., \& Co., 1833.

MAINE (State of). (First) Report Commissioners of Fisheries. (47th Legislature, Sen. No. 7.) 800 ordered printed Jan. 20, 1868. N. P. Stevens \& Sayward, Printers to the State.

MAINE. Reports of Commissioners of Fisheries, Years 1867 and 1868. 8vo. Augusta : 1869.

MAINE. Third Report of the Commissioners of Fisheries, State of Maine, 1869. Front. 8vo. Augusta: Sprague, Owen \& Nash, 1870.

MAINE. Fourth Report of the Commissioners of Fisheries, Year 1870. Plans. 8vo. Augusta: Sprague, Owen \& Nash, 1870.

MAINE. Fifth Report of the Commissioners of Fisheries, Year 1871. 8vo. Augusta: Spragde, Owen \& Nash, 1872.

MAINE. Sixth Report Commissioners of Fisheries, 1872. 8vo. Augusta: 1873.

MAINE. Seventh Report Commissioners of Fisheries, Year 1873. 8vo. Augusta: 1874.

MAINE. Eighth Report Commissioners of Fisheries, Year 1874. 8vo. Augusta: 1874.

MAINE. Ninth Report Commissioners of Fisheries, Year 1875. 8vo. Angusta: 1875.

MAINE. Report Commissioners of Fisheries and Game, 1880. 8vo. Augusta : 1880.

MAINE. Report of the Commissioners of Fisheries and Game, 1882. 8vo. Augusta: 1882.

MAINE. Report Commissioners of Fisheries and Game, Year 1883. 8vo. Augusta: 1883. 
Maine. Rept q Fon's of Fisheries Mame for Yjears 1891-1892 
MAINE. Report Commissioners of Fisheries and Game, Year 1884. 8vo. Augusta : 1884.

MAINE. Report Commissioners of Fisheries and Game, Year 1886. 8vo. Augusta: 1886.

MAINE. Report Commissioners of Fisheries and Game, Year 1888. 8vo. Augusta: 1888.

MAINE. A Memorial Relating to the Destruction of the State Fisheries, Presented to Congress, March 9, 1892, by the Commission of Sea and Shore Fisheries. 4to. Washington: 1892.

MAINIVARING (Hox. W. F. B. MASSEY). The Preservation of Fish Life in Rivers. 8vo. London: W. Clowes \& Sons, 1883.

MAITLAND (SIR J. RAMSAY GIBSON). The History of Howietoun. A Description of the Various Hatching Honses and Ponds, etc. Illustrated. 4to. Stirling: J. R. Goy, 1887.

MALET (H. P.) New Pages of Natural History. 8vo. London: T. Cautley Newby, 1868.

MANBY (GEO. WM.) Journal of a Voyage to Greenland in 1821, with Graphic Illustrations. Second Edition. 8vo. London: G. \& W. B. Whittaker, 1823.

MANCHESTER 'ANGLERS' ASSOCIATION. Anglers' Evenings. Papers by the Members. Three Series. 3 vols. Svo. Manchester and London: 1880-1894.

MANCHESTER ANGLERS' ASSOCIATION. Anglers' Evenings. Papers by the Members. Second Series. Illustrated. Larax PAPER. 4to. Manchester and London: 1882.

MANLEY (.I. J.) Notes on Fish and Fishing. Illustrated. $12 \mathrm{mo.}$ London: SAMPsoN Low, 1877.

MANLEY (J. J.) Notes on Fish and Fishing. I Ilustrated. Cheaper Edition. 12mo. London: Sampson Low, 1881.

MANLEY (J. J.) Literature of Sea and River Fishing. 8vo. London : W. Clowes \& Sons, 1883.

MARBURY (MARY ORVIS). Favorite Flies and their Histories. Thirty-two Colored Plates of Flies, six Engravings and eight reproductions of Photographs. Sq. 8vo. Boston and New York: Rrverside Press, 1892.

MARCH (J.) The Jolly Angler. 80 wood engravings. First Edition. 16mo. London: J. MARCH, 1833.

MARCH (J.) The Jolly Angler. 80 wood engravings. Second Edition. 16mo. London: J. Maroh, N. D. 
MARCH (J.) The Jolly Angler. 80 wood engravings. Third Edition. 12mo. (London) J. MaRCH, (1836).

MARCH (J.) The Jolly Angler. 80 wood engravings. Fourth Edition. 12mo. London: J. MARCH, N. D.

MARCH (J.) The Jolly Angler. 80 wood engravings. Fifth Edition. 16mo. London: J. MarCH, N. D.

MARCH (J.) The Jolly Angler. 80 wood engravings. Sixth Edition. 16mo. London: J. March, N. D.

MARCH (J.) The Jolly Angler. 80 wood engravings. Seventh Edition. 16mo. London: J. March, (1850).

MARCOU (JULES). Life, Letters and Works of Louis Agassiz. Illustrated. 2 vols. 8vo. New York and London: Macmillan, 1896.

MARKHAM'S (GERVASE). Farewell to Husbandry. Sq. $12 \mathrm{mo.}$ London: Printed by Wm. Wilsion for John Harison, 1649.

*By the same author (bound in), "A New Orchard and Garden." 1648, With illustrations.

MARKHAM (GERVASE). Country Contentments; or, The Husbandman's Recreations. Ninth Edition. Sq. 12mo. London: Printed By WM. Wilson for Geo. Sawbridga, 1660.

[MARKHAM (GERVASE).] Cheap and Good Husbandry. Eleventh Edition. Sq. 12mo. London: Prin'eed by W. Wilson for Geo. SaWbridge, 1664.

MARSH (GEO. P.) Report on the Artificial Propagation of Fish. 8vo. Burlington, Vt.: Free Press Print, 1857.

MARSHALL (CHAS.) A Plain and Easy Introduction to the Knowledge and Practice of Gardening, with Hints on Fish Ponds. Third Edition. 16mo. London: F. \& C. Rivington, 1800.

[MARSTON (EDWARD).] An Amateur Angler's Days in Dove Dale. 24mo. London: Sampson Low, 1884.

[MARSTON (EDWARD).] An Amateur Angler's Days in Dove Dale. Engraved title. 16mo. London: Sampson Low, 1884.

[MARSTON (EDWARD).] Frank's Ranch. Illustrated. $16 \mathrm{mo}$. Boston and New York: Riverside Press, 1886.

[MARSTON (EDWARD).] Fresh Woods and Pastures New. $16 \mathrm{mo.}$ London: SAMPsON Low, 1887.

[MARSTON (EDWARD).] Fresh Woods and Pastures New. $12 \mathrm{mo.}$ London: SAMPson Low, 1887.

* Large Paper.

[MARSTON (EDWARD).] Days in Clover. By The Amateur Angler. 24mo. London: SAMPson Low, 1892. 
wa

Z. 
Martin, M. A Late Voyage to st. Mitda. The Renelat of all the Alébrides te. 18: llap MPlate. Loud: Presited for D. Brown re. 1698 
[MARSTON (EDWARD).] Days in Clover. Illustrated. $16 \mathrm{mo.}$ London: SAMPSON Low, 1892.

* Large Paper. No. 20 of 250 printed.

[MARSTON (EDWARD).] By Meadow and Stream. India proof illustrations. $16 \mathrm{mo}$. London: SAMPSON Low, 1896.

* No. 153 of 250 printed on Van Gelder's hand-made paper.

[MARSTON (EDWARD).] "On a Sunshine Holyday." Illustrated. 16mo. London: Sampson Low, 1897.

[MARSTON (EDWARD).] "On a Sunshine Holyday." India proof illustrations. $12 \mathrm{mo}$. London: SAMpson Low, 1897.

* No. 240 of 250 printed on Van Gelder's hand-made paper.

[MARSTON (EDWARD).] An Old Man's Holidays. Japan proof illustrations. 12mo. London: SAMPSON Low, 1900.

* No 73 of 250 printed on Van Gelder's hand-made paper.

[MARSTON (EDWARD).] An Old Man's Holidays. Illustrated. 16mo. London: Sampson Low, 1900.

MARSTON (R. B.) Walton and Some Earlier Writers on Fish and Fishing. 16mo. London: Elliot Stock, 1894.

* Printed on antique paper, cloth, beveled edges.

MARSTON (R. B.) Walton and Some Earlier Writers on Fish and Fishing. 12mo. Roxburghe, London: Elliot Stook, 1894.

* Only 250 printed on hand-made paper.

MARSTON (R. B.) Walton and Some Earlier Writers on Fish and Fishing. Sq. 8vo. London: Eцliot Stock, 1894.

* Large Paper Edition on hand-made paper.

MAR'IN (EDWARD A.) A Bibliography of Gilbert White. Front. 12mo. (London) The Roxbdrghe Press, N. D.

[MARTIN (J.).] The Angler's Guide to the Horse and Groom, Lea Bridge and White Horse Fisheries, etc. Map. 24mo. First Edition. London: H. Brown, Engraver, ete., 1840.

MARTIN (Rev. JAMES). The Angler's Guide. Front. 16mo. London: H. Cox, 1854.

MAR'TIN (J. W.) Float Fishing and Spinning in the Nottingham Style. Illustrated. 12mo. London: SAMpson Low, 1882.

MARTIN (W.S.) and ROW (B. P.) Tonbridge: for The Resident, The Holiday Maker, and The Angler. Illustrated. 12mo. Tonbridge, London: N. D.

MARYLAND (STATE OF). Report of the Commissioners of Fisheries of Maryland, Jan. 1876. 8во. Annapolis: 1876. 
MARYLAND. Report of a Commissioner of Fisheries of Maryland, Jan. 1887. 8vo. N. P.: King Bros., Printers, 1877.

MARYLAND. Report of a Commissioner of Fisheries of Maryland, Jan. 1878. 8vo. Baltimore: 1878.

MARYLAND. Report of the Commissioners of Fisheries of Maryland, Jan. 1880. 8vo. Annapolis: 1880.

MARYLAND. Report of T. B. Ferguson, a Commissioner of Fisheries of Maryland, Jan. 1891. 8vo. Hagerstown: 1881.

MASANIELLO. The Fisherman of Naples. History of His Rise and Fall. Front. 16mo. London: J. Browne, 1768.

MASCALL (LEONARD). A Book of Fishing With Hook and Line. Sq. 8ro. London: W. Satohell \& Co., 1884.

MASSACHUSETTS (STATE OF). Reports of the Commissioners on the Zoological Surrey of The State. 8vo. Boston: 1838.

MASSACHUSETTS. Report of Commissioners Appointed Under Resolve of 1856. Chap. 58, on Artificial Propagature of Fish, etc. 8vo. Boston: 1857.

MASSACHUSETTS. Report of Commissioners Concerning the Artificial Propagation of Fish, etc. 8vo. Boston: 1857.

MASSACHUSET'TS. Report Joint Special Committee upon the Subject of the Obstruction to the Passage of Fish in the Connecticut, Merrimack and Saco Rivers. 8vo. N. P.: A pril 6, 1865.

MASSACHUSETTS. First Report, Commissioners of Fisheries. Nov. 30, 1866. 8vo. N. P.: 1866. (House No. 3.)

MASSACHUSETTS. Report of Commissioners concerning the Obstructions to the Passage of Fish in the Connecticut and Merrimack Rivers. (Senate No. 8.) 8vo. Boston: Jan. 10, 1866.

MASSACHUSET'TS. Report of the Commissioners appointed under the Resolve of May 3, 1865, "Concerning the Obstruction of Fish in the Connecticut and Merrimack Rivers." (Senate No. 8.) 8ro. Boston: 1866.

MASSACHUSEI'TS. An Act for Encouraging the Cultivation of Useful Fishes. (Senate No. 91.) 8vo. N. P.: N. D. (1869.)

MASSACHUSETTS. (Second) Report of the Commissioners of Fisheries. Year ending Jan. 1, 1868. 8ro. Boston: 1868.

MASSACHUSETTS. Report of the Commissioners of Wisheries. Year ending Jan. 1, 1869 . 8vo. Boston: 1869.

MASSACHUSETTS. Report (Fourth) of the Commissioners of Fisheries. Year ending Jan. 1, 1870. 8ro. Boston: 1870. 
Masaniello. The Fisherman of Naples. Portrait C.80 Thy F. icon, fr. Leuchi Printed for C. Davis, lyra. 


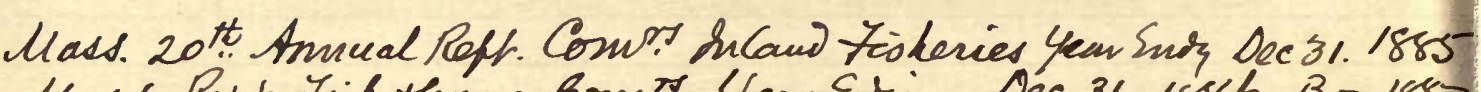
Mass. Repr. Fish racume bonn? Year Ering Dec 31. 1886 Bos.1887 
MASSACHUSET'IS. Fifth Annual Report of the Commissioners of Inland Fisheries. Jan. 1871. 8vo. Boston: 1871.

MASSACHUSETTS. Sixth Annual Report, Commissioners on Inland Fisheries. Year ending Jan. 1, 1872. 8vo. Boston: 1872.

MASSACHUSETTS. Seventh Annual Report, Commissioners on Inland Fisheries. Year ending Jan. 1, 1873. 8vo. Boston: 1873.

MASSACHUSETTS. Eighth Annual Report, Commissioners on Inland Fisheries. Year ending Jan 1, 1874. 8vo. Boston: 1874.

MASSACHUSETTS. Ninth Annual Report, Commissioners on Inland Fisheries. Year ending Jan. 1, 1875. 8vo. Boston : 1875.

MASSACHUSET'TS. Tenth Annual Report, Commissioners on Inland Fisheries. Year ending Jan. 1, 1876. 8vo. Boston: 1876.

MASSACHUSETTS. Eleventh Annual Report, Commissioners on Inland Fisheries. Year ending Jan. 1, 1877. 8vo. Boston: 1877.

MASSACHUSETTS. Twelfth Annual Report, Commissioners on Inland Fisheries. Year ending Jan. 1, 1878. 8vo. Boston : 1878.

MASSACHUSEITS. Thirteenth Annual Report, Commissioners on Inland Fisheries. Year ending Sept. 30, 1878. 8vo. Boston: 1879.

MASSACHUSETTS. Fourteenth Annual Report, Commissioners on Inland Fisheries. Year ending Sept. 30, 1879. 8vo. Boston: 1880.

MASSACHUSETTS. Fifteenth Annual Report, Commissioners on In. land Fisheries. Year ending Sept. 30, 1880. 8vo. Boston: 1881.

MASSACHUSETTS. Sixteenth Annual Report, Commissioners on Inland Fisheries. Year ending Sept. 30, 1881. 8vo. Boston: 1882.

MASSACHUSETTS. Seventeenth Annual Report, Commissioners on Inland Fisheries. Year ending Dec. 31, 1882. 8vo. Boston: 1883.

MASSACHUSETTS. Eighteenth Annual Report, Commissioners on Inland Fisheries. Year ending Dec. 31, 1883. 8vo. Boston: 1884.

MASSACHUSETTS. Nineteenth Annual Report Commissioners on Inland Fisheries, year ending Dec. 31, 1884. 8vo. Boston: 1885.

MASSACHUSETTS. Fish and Game Protective Association. An Address. By Edward A. Samuels, Prest. 12mo. Boston: 1888.

MASSACHUSETI'S. Annual Report of the Massachusetts Fish and Game Protective Association, 1892. 8vo. Boston: 1892.

MASSACHUSET'L'S. Walter L. Gilbert, Vice Commissioner of Massachusetts, in the Matter of the Trout Supply. Points for the Defendant. 8vo. Boston: A. C. Grтohell, 1893. 
MASSACHUSETTS. Laws Relating to Inland Fisheries in Massachusetts, 1623-1886. 8vo. Boston: 1887.

MASSACHUSE'TTS. Remarks of Col. Theodore Lyman, Commissioner of River Fisheries (on the Fishery Act), March 11, 1869. 8vo. N. P.

MASSACHUSE'TS. Arguments on Sea, Coast and River Fishing. 8 ro. Boston : 1879.

MASSACHUSE'TS. Manchester vs. The Commonwealth of Massachusetts on the Fisheries of the Marine Belt. Argument by Jos. H. Choate. 8vo. Fall River: N. D.

MASSAS (CHAS. DE). Le Pêcheur a la Mouche Artificielle et le Pêcheur a Toutes Lignes. Quatrieme Edition. 80 vignettes. $12 \mathrm{mo}$. Paris : N. D.

MAST (REv. ISAAC). The Gun, Rod and Saddle. 16mo. Phila:: M. E. Book and Publishing House, 1875.

MATHER (FRED.) Memoranda Relating to the Adirondack Fishes. 8vo. Albany: 1886.

MATHER (FRED.) Men I Have Fished With. Portraits. 8vo. New York: Forest and Stream, 1897.

MATHER (FRED.) In the Louisiana Lowlands. 12mo. New York: Forest and Stream, 1900.

MATHER (FRED.) Modern Fish Culture in Fresh and Salt Water. Illustrated. 12mo. New York: Forest and Stream, 1900.

MAUNDER (SAMUEL). Treasury of Natural History. 900 illustrations. New Edition. 16mo. London: Longmans, 1849.

MAXWELL (SIR HERBERT). Memories of the Months. Illustrated. 12mo. London and New York: E. Arnold, 1897.

MAXWELL (Sin HERBERT). Memories of the Months. Tinted Plates. 8vo. London: ED. Arnown, 1900.

[MAXWELL (W. H.)] Wild Sports of the West. Illustrated. 2 vols., 8vo. London: R. Bentley, 1832.

[MAXWELL (W. H.)] Field Book. Illustrated. 8vo. London: EFfingham Wilson, 1833.

MAXWELL (W. H.) Wanderings in the Highlands and Islands. Portrait. 2 vols. 8vo. London: A. H. BaIly \& Co., 1844.

[MAXWELL (W. H.)] Wild Sports of the West. Third Edition. 2 vols. $12 \mathrm{mo}$. New York: Harpers, 1847.

MAXWELL (W. H.) Wild Sports and Adventures. Front. and Vignette. 16mo. London: Routledge, 1853. 

[MAXWELL (W. H.)] Field Book. Illustrated. 8vo. London: W. TWEEDIE, N. D.

MAYER (ALFRED M.) Sport with Gun and Rod. India Proof and other Illustrations. 4to. New York: Century Co., 1883.

MAYER (ALFRED M.) Sport with Gun and Rod in American Woods and Waters. India Proof and other Mlustrations. 4to. New York: Century Co., 1883.

MAYER (JOHN). The Sportsman's Directory. Frontispiece. Third Editioll. London: BaLdwin, Cradock \& JoY, 1819.

MAYER (JOHN). Sportsman's Directory. Sixth Edition. Illustrated. 16mo. Simpkin, Marshall \& Co., 1838.

MAYER (JOHN). Sportsman's Directory. Seventh Edition. Illustrated. 16mo. London: Simprin, Marshalt \& Co., 1845.

McCARTHY (EUGENE). The Leaping Ouananiche. Map and Illustrations. Sq. 8vo. New York: Forest and Stream, 1894.

McCARTHY (EUGENE). Familiar Fish, Their Habits and Capture. Illustrated. 12mo. New York: D. Appleton \& Co., 1900.

McCARTHY (EUGENE). A Tale of Lake St. John. Illustrated. Sq. 16mo. Montreal: Desbarats \& Co., N. D.

MoCLELLAND (H. G.) The Trout Fly Dressers' Cabinet of Devices. 80 illustrations. 16mo. London: SAMPson Low, 1899.

McCORMICK (LEWIS M.) Descriptive List of the Fishes of Lorain Co., O. Illustrated. 8vo. Oberlin, O.: 1892.

McCULLOCH (LEWIS). Observations on the Herring Fisheries upon the North Coast of Scotland, etc. 8vo. London: W. Richardson, 1788.

McGAFFEY (ERNEST). Poems of the Gun and Rod. Illustrated. Sq. 8vo. New York: Chas. Scribner's Sons, 1892.

McGREGGOR (J.) The Rob Roy on the Baltic. Maps and Illustrations. 16mo. Second Edition. London: Sampson Low, 1867.

McLELLAN (ISAAC). Poems of the Rod and Gun. Etched Frontispiece. 12mo. New York: Henre Thorpe, 1886.

MEDWIN (THOS.) Angler in Wales. Illustrated. 2 vols. 8 vo. London : R. Bentuey, 1834.

MEEHAN (WM. E.) Fish, Fishing and Fisheries of Penna. Illustrated. 8vo. Harrisburg: 1893.

MELVILLE (HERMAN). Moby-Dick; or, The Whale. 12mo. New York: HARPERS, 1871. 
MENHADEN (THe) Fishery of Maine. Illustrated. 8vo. Portland: B. Thurgton \& Co., 1878.

MENNIER (VIC'TOR). Les Grandes Pêches. Ouvrage Illustré de 85 Vignettes. 12mo. Paris: 1868.

MEREDITH (LOUISA ANNE). Tasmanian Friends and Foes. Col ored Plates. Second Edition. Sq. 8vo. London: Marcus Warn \& Co., 1881.

MERRIFIELD (MRs.) A Sketch of the Natural History of Brighton. Map and Front. 12mo. Brighton: W. Pearce, 1860.

MERIONETHSHIRE (THE) Angler. 12mo. Barmouth: OwEN JoNes, N. D.

METCALFE (Rev. FRED'K). The Oxonian in Norway. Map and Illustration. Second Edition. 12mo. London: Hurst \& BACKETT, 1857.

MICHIGAN (S'IATE OF). First Report of the Commissioners on State Fisheries, 1873-4. 8vo. Lansing: 1875.

MICHIGAN. Second Report State Comrs. and Supt. State Fisheries, 1875-6. 8vo. Lansing: 1876.

MICHIGAN. 'Third Report Supt. State Fisheries for 1877-8. 8vo. Lansing: 1879.

MICHIGAN. Fourth Report State Comrs. and Supt. State Fisheries, 1879-1880. 8vo. Lansing: 1881.

MICHIGAN. Fifth Biennial Report Supt. State Fisheries for 1881-2. 8vo. Lansing: 1883.

MICHIGAN. Sixth Biennial Report State Board Fish Comrs., 1883-4, ending Dec. 1, 1884. 8vo. Lansing: 1885.

MICHIGAN. Seventh Biennial Report State Board Fish Comrs., Dec. 1, 1884 ; Dec. 1, 1886. 8vo. Lansing: 1887.

MICHIGAN. Eleventh Biennial Report State Board of Fish Comrs., Dec. 1, 1892; Dec. 1, 1894. 8vo. Lansing: 1895.

MICHIGAN. Forests, Streams, Lakes, etc. of Northern Michigan. Map and Front. 8vo. Marquette: L. P. Crarx, 1884.

MILES (HENRY DOWNES). Hook of Field Sports. Plates of Colored Filies, etc. 2 vols. 4to. London: N. D.

MILFORD (JOHN). Norway and Her Laplanders in 1841. 8ro. London: J. Murray, 1842.

* Large Paper.

MILLARD (E. E.) Random Casts, etc. From an Angler's Note Book. By E. M. E. 16mo. New York: Deriy Bros., 1878. 


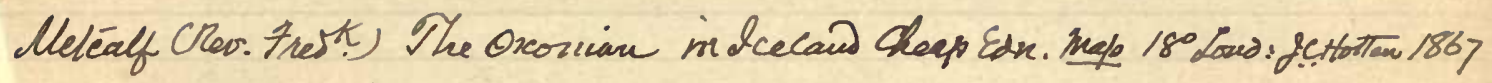




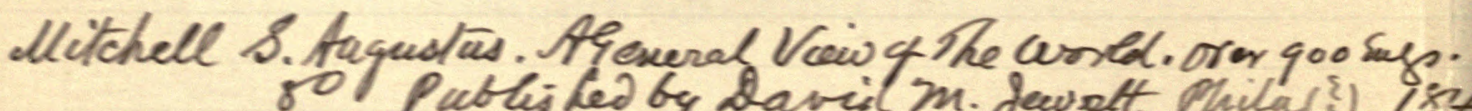
Publisted by david M. Javolt Phila(?) ist 
MILLER (JAMES WILLIAM). Poems and Sketches. 12mo. Boston: Eastburn's Press, 1830.

MILLER (THOS.) Beauties of the Country. 261 llustrations. $12 \mathrm{mo}$. London: VAN Voorst, 1837.

MILLER (THOS.) Rural Sketches، 23 Illustrations. 12mo. London: VAN VoORST, 1839.

MILLER (THOS.) Sports and Pastimes of Merry England. 21 Illustrations. 12mo. London: Darton \& Co., N. D.

MILLS (JOHN). The Sportsmau's Library. Portrait and Engravings. 8vo. Edin.: WM. Paterson, (1845).

MILLS (JOHN). The Sportsman's Library. 12mo. Phila.: LEA \& BLANOHARD, 1846.

[MILNER (WM. JR.)] An Authenthic Historical Memoir of the Schuylkill Fishing Company of the State in Schnylkill. By a Member. Illustrated. 8vo. Original Cloth. Phila.: Published by Judan Dobson, 1830.

MILNER (WM. JR.) A History of the Schuylkill Fishing Company of the State in Schuylkill, 1732-1888. Illustrated. 4to. Phila.: Purlished bx the Menibers, 1889.

MINNESOTA (STATE OF). First Annual Report State Fish Comrs. of Minnesota. 8vo. St. Paul: 1875.

MIN NESOTA. Fourth Annual Report of the State Fish Comrs. of Minnesota, year ending Dec. 31st, 1877. 8vo. Minneapolis: JонNson, SMith \& Harrison, 1878.

MINNESO'TA. Fifth Annual Report of the State Fish Comrs. of Minnesota, year ending Dec. 31st, 1878. 8vo. Minneapolis: JoHnson, SMITH \& HARRISON, 1879.

MINNESO'TA. Sixth and Seventh Aunual Reports of the Minnesota State Fish Comn, years 1879-80. 8vo. St. Peter: J. K. Moore, 1881.

MINNESOTA. Game and Fish Laws of Minnesota. 24mo. St. Paul : Pioneer Press, 1897.

MISSOURI (STATE OF). Third Biennial Report of the Fish Commission. Years 1883-84- 8vo. Jefferson City: 1885.

MISSOURI P. R. W. CO. Notes on the Scenery, Game and Fish of Arkansas. Illustrated. 12mo. St. Lovis, Mo.: 1898.

[MITCHELL (DONALD G.)] Wet Days at Edgewood. 12mo. New York : Chas. Scrimner, 1865.

[MITCHELL (DONALD G.)] Wet Days at Edgewood. 12mo. New York: Chas. Scribner's Sons, 1884. 
MITCHELL (S. WEIR). When all the Woods are Green. Portrait. 12mo. New York: Century Co., 1897.

MITCHELL (WM. ANDREW). On the Pleasure and Utility of Angling. Vignette. 12mo. Newcastle-on-Tyne: For The WaLtonian Club, (1824).

MITCHELL (W. STEPHEN). On the Place of Fish in a Hard Working Diet, and Fish as a Food. By Sir H. Thompson. 8vo. London : W. Clowes \& Sons, 1884.

MODERN (THE) ANGLER. Water-colored Engravings of Fish. Narrow 12mo. Derby: Thos. Richardson, N. D.

MOFFAT (A. S.) The Secrets of Angling. Illustrated. 12mo. Edinburgh : A. \& C. BLACK, 1865.

MONRO (ALEX.) New Brunswick, Nova Scotia and Prince Edward Island. Maps. 8vo. Halifax, N. S.: Rrohd. Nugent, 1855.

MONTPETIT (A. N.) Les Poissons D'Eau Douce du Canada. Illustrations (some colored). 4to. Montreal : 1897.

MOORE (GEO. H.) Washington as an Angler. Portrait inserted. 12mo. New York: For the Autror, 1887.

MORE (Sir J.) England's Interest, or the Gentleman and Farmer's Friend. Third Edition. 24mo. London: Printed AND sold BY J. How, 1705.

[MOREAU (F. A.)] Recherches Physiologiques sur la Vessie Natatoire Role Hydrostatique de cet Organe. Plates. 8vo. Paris: 1877.

MORICEAU (A.) Le Guide et les Droits des Pêcheurs a la Ligne. Plates. 12mo. Paris: 1882.

MORGAN (GEO.) The New Complete Sportsman. Front. $16 \mathrm{mo.}$ London: Alex. Hoge, (1747).

MORIN (A. B.) and MANDUIT (J). Guide Pratique du Pêcheur. Illustrated. 16mo. Paris: 1877.

MORRIS (JOS. E.) Surrey's Capital. A Handbook for Guildford. Chapter on Angling. Illustrated. 12mo. Guildford and London: N. D.

MORRIS (ROBT. T.) Hopkins's Pond and other Sketches. Front. 12mo. New York and London: G. P. Putnam's Sons, 1896.

MORTON (HoN: LEVI P.) Fisheries and Fish Culture, Speech of Hon. L. P. Morton, February 4, 1880. 8vo. Washington : 1880.

MOSER (JEFFERSON F.) Salmon and Salmon Fisheries of Alaska. Illustrated. 4to. Washington: 1899. 


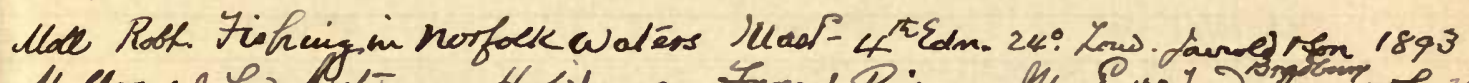

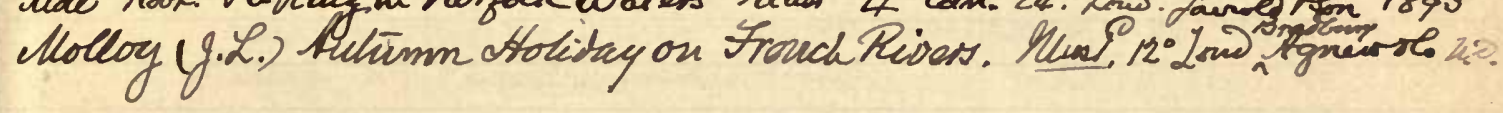




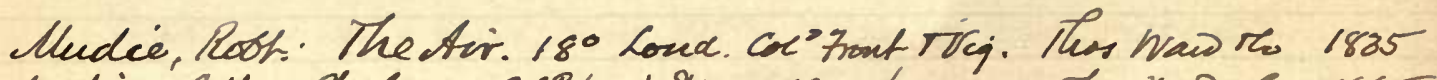

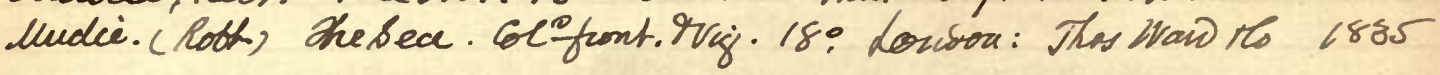

Napier, Char. O. Income. The Book g' Nature The Book of Maw, with

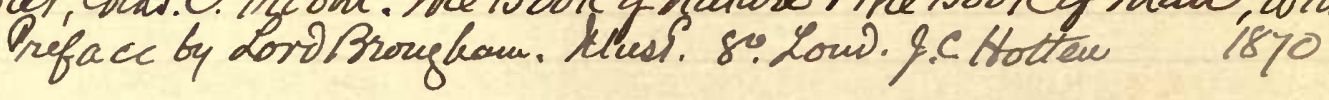


MOULE (THOS.) Heraldry of Fish. Illustrated. 8ro. London : VAN VOORST, 1842.

MULERTT (HUGO). How to Cook Fish. Second Edition. $16 \mathrm{mo}$. Cincinnati : H. MULertT, 1887.

MUFFETT (THOS.) Heath's Improvement, or Rules Comprising and Discovering the Nature, Method and Manner of Preparing All Sorts of Food. Corrected and enlarged by Chris. Bennet. Sq. 12mo. London: Printed by 'Tho. Newcomb for Saml. Thomson, 1655.

MUNRO (A. G.) Rochester and Chatham with Pen and Camera. Map and Illustrations. 12mo. Rochester: 'T. OLDroyd, N. D.

MURDOCH (W. G. BURN). From Edinburgh to the Antarctic. Sketches during the Dundee Antarctic Expedition 1892-93. Illustrated. 8vo. London: Longmans, 1894.

MURRAY (WM. H. H.) Adventures in the Wilderness. Illustrated. 16mo. Boston: Fresds, Osgood \& Co., 1869.

MURRAY (WM. H. H.) Adventures in the Wilderness. Illustrated. 16mo. Boston: Fields, Osaood \& Co., 1870.

MURRAY (W. H. H.) Adirondack 'l'ales. Illustrations. Sq. $12 \mathrm{mo}$. Boston: Golden Role Publishing Co., 1877.

MURRAY (W. H. H.) How Deacon Tubman and Parson Whitney Kept New Years. Illustrated. 12mo. St. Johnsbury, Vt.: Caledonia Countr Publishing Co., 1887.

MURRAY (WM. H. H.) Daylight Land. 140 designs in colors. 8 vo. Boston: CUPples \& Hurd, 1888.

MURRAY (W. H. H.) Lake Champlain and its Shores. Portrait. 12mo. Boston: De Wolfe, Fiske \& Co., (1890).

MURRAY (WM. H. H.) Adventures in the Wilderness. 1llustrated. 16mo. Boston: De Wolfe, Fiske \& Co., N. D.

MURRAY (W. H. H.) (Adrrondack). Cones for the Camp Fire. $12 \mathrm{mo.}$ Boston : De Wolfe, Fiske \& Co., N. D.

MURREY (THOS. J.) Oysters and Fish. 16mo. New York: F. A. Stokes \& BRo., 1888.

NAPLES. Guide to the Aquarium of the Zoological Station at Naples. Fourth Edition, with 175 Illustrations. 8vo. Leipzic: BREITKOPF \& HARTEL, 1896.

NAPLES. Guide pour L'Aquarium de la Station Zoologique de Naples. Quatrieme Edition. 167 Illustrations. 8vo. Naples: 1898. 
NAPLES. Guida per L'Acquario della Statzione Zoologica di Napoli. Quarta Edizione. 175 Illustrations. 8vo. In Modena: 1898.

NATIONAL (The) Fish-Culture Association of Great Britain and Ireland. By-Laws. 8vo. London: 1883.

NATIONAL FISHERY ASSOCIATION. Organization, Platform and By-Laws, Gloucester, Mass., Feb., 1887. 8vo. Printed at the Cape Ann Advertiser Office, 1887.

NATURAL (A) History of Fishes. 40 Engravings. 24mo. Alnwick: W. Davison, N. D.

NEEDHAM (T. H.) Complete Sportsman. 12mo. London: W. Simpkin aNd R. Marshall, 1817.

NEGRI (LUIGI DE). La Pesca e la Societa di Piscicolture Italiana. Charts. 4to. Paris: 1874.

NEIL'S (A.) Complete Angler. Front. Seventh Edition. $16 \mathrm{mo.}$ London: A. NerL, N. D.

NEIL'S (A.) Complete Angler. Front. Tenth Edition. 12mo. London : A. NeIL, N. D.

NEIL'S (A.) Complete Angler. Front. Fourteenth Edition. $12 \mathrm{mo.}$ London: Printed and Published by A. Neil, 1804.

NEIL'S (A.) Complete Angler. Frontispiece of Fish. Fifteenth Edition. 12mo. London: T. Hughes, N. D.

NEIL'S (A.) Complete Angler. Colored Front. Twentieth Edition. 12mo. London: Printed for T. Hughes, N. D.

NELSON (WM.) The Laws Concerning Game ; of Hunting, Hawking, Fishing, Fowling, etc. Sixth Edition. 16mo. London : Printed BY E. RichaRdson and C. Lintor, 1762.

NETTLE (RICH'D). The Salmon Fisheries of the St. Lawrence. 12 mo. Montreal : I. Lovel, 1857.

NEW BRUNSWICK RAILWAY. Angling and Hunting. Illustrated. Sq. 8ro. Camden, Me.: Geo. H. Haynes, N. D.

NEWFOUNDLAND FISHERIES. Correspondence Respecting, 1884-90. France, No. 1. Folio. London: N. D.

NEW HAMPSHIRE (STATe of). Report of the Comrs. of Fisheries, June Session, 1870. 8vo. Manchester : 1870.

NEW HAMPSHIRE. Report of the Comrs. of Fisheries, June Session, 1871. 8vo. Nashua: 1871.

NEW HAMPSHIRE. Report of the Comrs. on Fisheries, S. N. H., June Session, 1872. 8vo. Manchester : 1872. 
Nataral Atistory. Elements of. 2 vols s: Low. 9. Cadell prse 1801

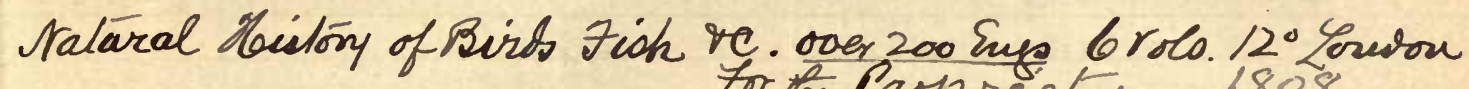
Tor the Propercetor 1808

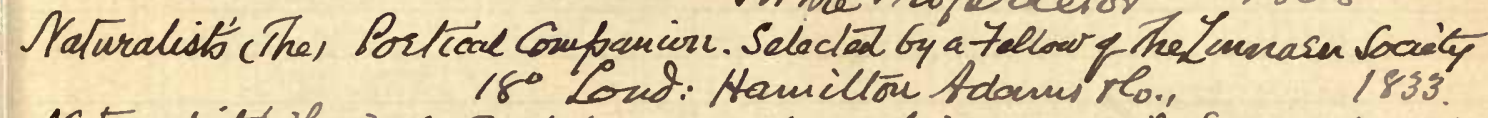

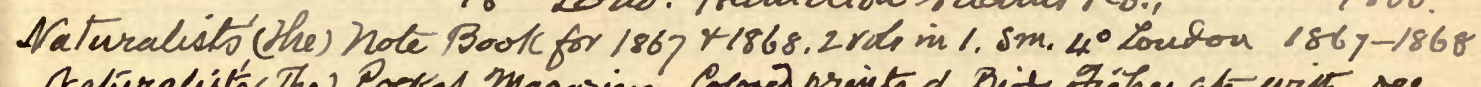
satiralistó (The) Pooket Magagine. Cocosed prints of Bits Trokes ats with ses-

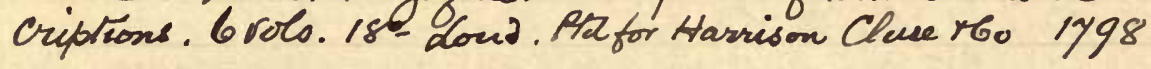

N.At, Report of the Select Comtee on tisheries Jnme Sescion 1865 N.At " "It" "Comps of Fisheries grme session 1866

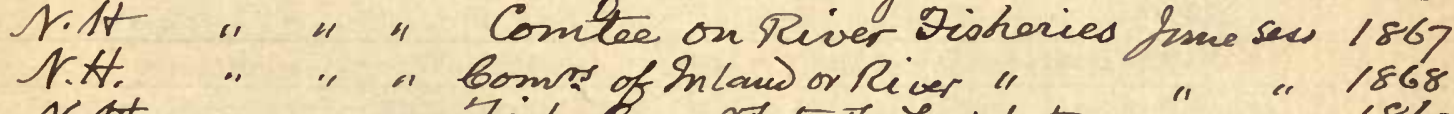

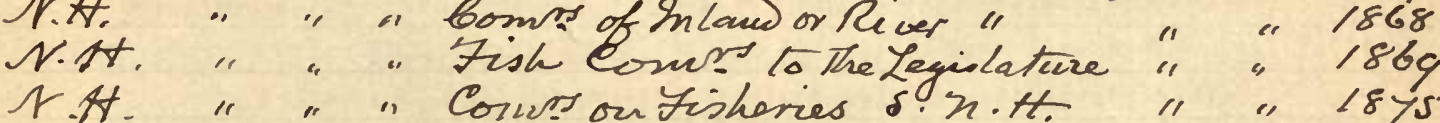

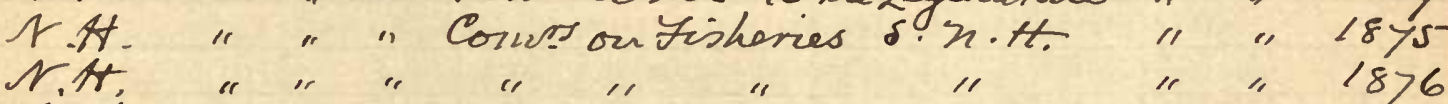

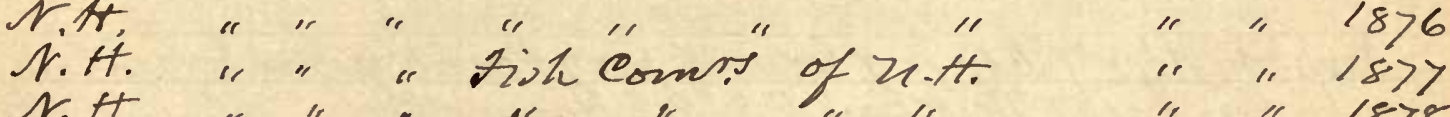

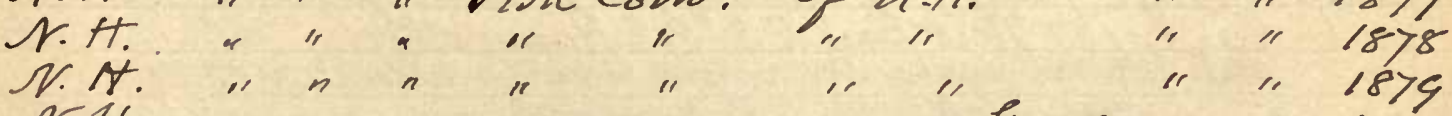

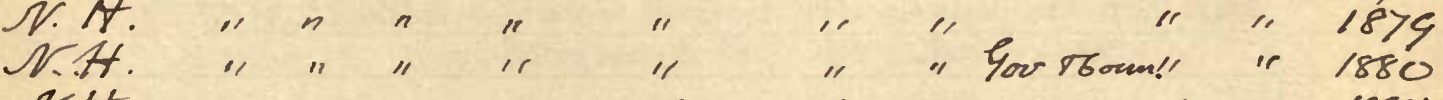

r.t. " " " " "G" " " " "1881

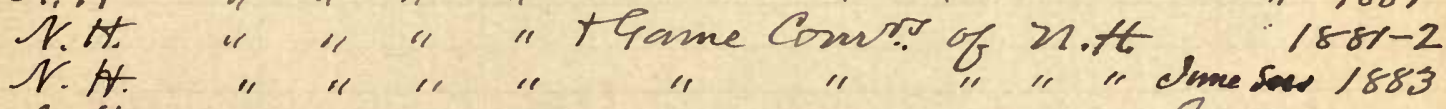

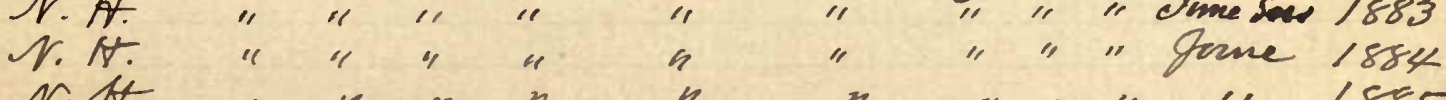

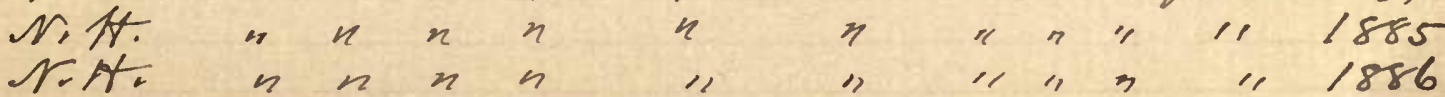

厝

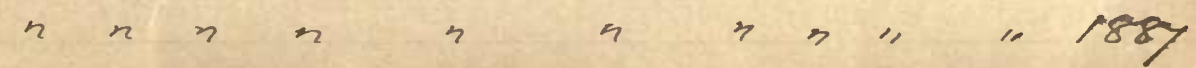




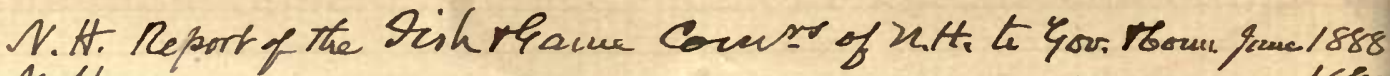

N.H.

N.H.

Vol. 1 PL 2 N. H. Voll" 3 N.T. Vol.1.pets N.S.

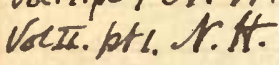

Hame Laws of The State of hew Samp hire For 1868 Iohn 3 blaske Mlauckester 1868 "184y E.a.gents

"1878 John Bolarke Seacchertas 1848

"1879 Johu B. blante Cancherter 1879

"1879 Same cuitt freited Cunenturens 1879

"1882 Dotur Bflarke Marchester 2858

"1882 " " " " " 1887

"1890 Eo" "in "Pearson Concord 1895

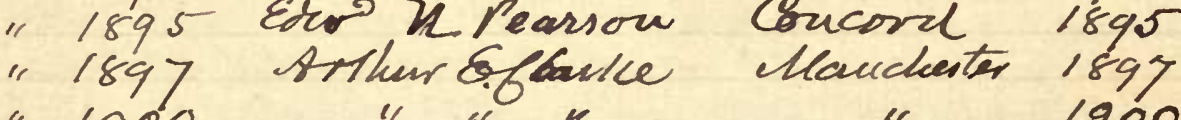
"1900" " " 1900

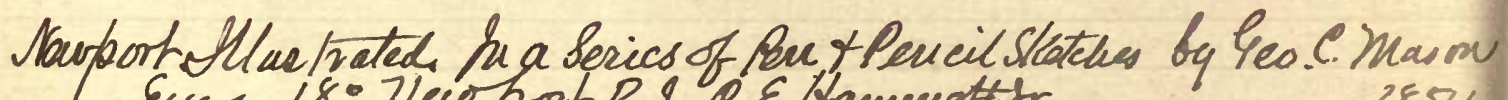
Eugs. 18 - 21eio port.RI. C.E./tamuottyr.

3854 
NEW HAMPSHIRE. Report of the Comrs. Fisheries, S. N. H., June Session, 1873. 8vo. Nashua : 1873.

NEW HAMPSHIRE. Report of the Comrs. on Fisheries, June Session, 1874. 8vo. Concord: 1874.

NEWHOUSE (S.) The Trappers' Guide. Second Edition, with new Narratives and Illustrations. 8vo. Wallingford, Ct.: PणB. BY Oneida Community, 1867.

NEW JERSEY (State of). Second Annual Report, Comrs. of Fisheries, 1872. 8vo. Trenton : 1872.

NEW JERSEY. Third Annual Report, Comrs. of Fisheries, 1872. 8vo. Trenton: 1872.

NEW JERSEY. Fourth Annual Report, Comrs. of Fisheries, 1873. 8vo. Trenton : 1873.

NEW JERSEY. Fifth Annual Report, Comrs. of Fisheries, 1874. 8vo. Trenton: 1874.

NEW JERSEY. Sixth Annual Report, Comrs. of Fisheries, 1875. 8vo. Trenton : 1875.

NEW JERSEY. Seventh Annual Report, Comrs. of Fisheries, 1876. 8vo. Trenton : 1876.

NEW JERSEY. Eighth Annual Report, Comrs. of Fisheries, 1877. 8vo. Trenton : 1877.

NEW JERSEY. (Ninth) Report, Comrs. of Fisheries, 1878. 8vo. Trenton : 1878.

NEW JERSEY. Report of the Comrs. of Fisheries, 1879-1883. 8vo. Trenton : 1883.

NEW JERSEY. Report of the Comrs. of Fisheries, 1884-5. 8vo. Trenton: 1886.

NEWLAND (REv. HENRY). The Erne, its Legends and its Fly Fishing. Front. of Colored Flies and other Illustrations. First Edition. 12mo. London: Chapman \& Hall, 1851.

NEWLAND (REv. HENRY). Forest Scenes in Norway and Sweden. 1llustrated. First Edition. 12mo. London: Rovtledae, 1854.

NEWLAND (Rwv. HENRY). Forest Scenes in Norway and Sweden. Illustrated. Second Edition. 12mo. London : Routledge, 1855.

NEWPOR'T. A Hand-Book of Newport, Rhode Island. Front. of the "Old Stone Tower." 16mo. Newport, R. I.: C. E. HAMMetr, JR., 1852.

NEWPORT. Natural History Society. Proceedings of 1891-1899. Number IX. 8vo. Newport, R. I.: F. W. Marshall, 1900. 
NEWSPAPER, and Other Kinds of Trout Illustrations, and Clippings of Fish and Angling Articles from Newspapers, etc. 3 4to volumes. N. P., N. D.

NEW YORK (STATE OF). Report, in part, of Samuel L. Mitchell, M. D., on the Fishes of New York. 16mo. New York: Printed bX D. Carlisle, Jan. 1, 1814.

NEW YORK. Transactions of the Literary and Philosophical Society of New York. 4to. N. Y.: VAN WinkLE \& Wiley, 1815.

* Contains Fishes of New York by Samuel L. Mitchell.

NEW YORK. Report of the Committee on Agriculture in Relation to the Petition of Robert L. Pell, Concerning Salmon Fisheries in the State. 8vo. Albany: 1857.

NEW YORK. First Annual Report Com'rs of Fisheries, March 9, 1869. 8vo. Albany: 1869.

NEW YORK. Second Annual Report Com'rs of Fisheries, March 11, 1870. 8vo. Albany: 1870.

NEW YORK. Third Annual Report Com'rs of Fisheries, Feb. 28, 1871. 8vo. Albany : 1871.

NEW YORK. Fourth Annual Report Com'rs of Fisheries, March 19, 1872. 8vo. Albany : 1872.

NEW YORK. Report Com'rs of Fisheries (Fifth), Feb. 12, 1873. 8vo. Albany: 1873.

NEW YORK. Sixth Annual Report Com'rs of Fisheries, Feb. 5, 1874. 8vo. Albany : 1874.

NEW YORK. Seventh Annual Report Com'rs of Fisheries, Feb. 1, 1875. 8vo. Albany: 1875.

NEW YORK. Eighth Annual Report Com'rs of Fisheries. Year ending Dec. 31, 1875. 8vo. (Albany), 1876.

NEW YORK. Tenth Annual Report N. Y. Fishery Com'rs. Year 1877. 8vo. Albany: 1878.

NEW YORK. Eleventh Report Com'rs of Fisheries, for two Years, ending Dec. 31st, 1879. 8vo. N. P.: April 1, 1880.

NEW YORK. Annual Report of the Com'rs of Fisheries (Twelfth). Year 1881. 8vo. Albany: 1882.

NEW YORK. Thirteenth Report Com'rs of Fisheries (Biennial). 8vo. Albany : 1884.

NEW YORK. Thirteenth Report of the Com'rs of Fisheries. Biennial Report. Feb. 1, 1884. 8vo. Albany: 1884. 
19

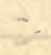

$\because$ 
Newryork. Fiskeries Same an For est Law Revised1895 Amend-1896 
NEW YORK. Fourteenth Report Com'rs of Fisheries. Biennial Report. May 10, 1886. 8vo. Albany, 1886.

NEW YORK. Seventeenth Report Com'rs of Fisheries. Jan. 10, 1889. 8vo. Albany: 1889.

NEW YORK. Nineteenth Report Com'rs of Fisheries. Jan., 1891. 8vo. Albany : 1891.

NEW YORK. First Annual Report of the Commissioners of Fisheries, Game and Forests of the State of N. Y. 4to. Albany: 1895.

NEW YORK. Second Annual Report of the Comrs. of Fisheries, Game and Forests of the State of N. Y. Illustrated. 4to. Albany : 1897.

NEW YORK. Third Annual Report of The Comrs. of Fisheries, Game and Forests of The State of New York. Colored and Plain Illustrations. 4to. Albany: 1898.

NEW YORK. Fourth Annual Report of the Comrs. of Fisheries, Game and Forests. Colored and plain Illustrations. 4to. Albany: 1899.

NEW YORK. Fisheries of the State of New York. Years 1869-1891. 3 vols. 8vo. Albany: 1869-1891.

NEW YORK STATE Association for the Protection of Fish and Game. Illustrated. 4to, cloth. Brooklyn, N. Y.: L. I. Sportsmen's Asss., 1881.

NEW YORK TRIBUNE BOOK of Open-Air Sports. Edited by Henry Hall. Illustrated. 8vo. New York: Tribune Assn., 1887. NEW YORK STATE GAME LAWS. 8vo. New York and Albany: BANKS Bros., 1892.

NEW YORK, Ontario and Western Railway. Hunting and Fishing. Illustrated. 8vo. New York: 1898.

NEW YORK AQUARIUM. Official Guide. Illustrated. 12mo. New York: G. E. JenNings, 1899.

NICOLS (ARTHUR). The Acclimatisation of the Salmonidæ at the Antipodes. 12mo. London: Sampson Low, 1882.

[NOBBES (RO.)] The Compleat Troller; or, The Art of Trolling. By a Lover of the Sport. First Edition. 24mo. London: Privted by T. James for Tho. Helder at the Angel in Little Britain, 1682.

NOBBS (ROBERT). The Compleat Troller; or, The Art of Trolling. 16mo. H. K. Causton, Printer, Birohin-Lane, Cornhill, N. D.

* N. P. or date on title. Imprint as above at foot of last page. 
NOEL (EUGIENE). Pisciculture Pisciculteurs et Poissons. 12mo. Paris : 1856.

NONNIUS. Ludovici Nonni Medici Ichtyophagia Sive De Piscium esv Commentarius (printers device on title.) 16no. Antverpiœ. Apud Perrom and Ioannedr Belleros. M.DC.XVI.

NORDHOFF (CHARLES). Whaling and Fishing. Frontispiece. $16 \mathrm{mo}$. Cincinnati: Moorre, WII stach, Keys \& Co., 1856.

NORRIS (THAD.) The American Angler's Book. Eighty Engravings. 8vo. Phila.: E. H. Butler \& Co., 1864.

NORRIS (THAD.) American Angler's Book. 80 Engravings. New Edition with a Supplement. 8vo. Phila. : E. H. Butler \& Co., 1865.

NORRIS (THAD.) American Fish Culture. Illustrated. 12mo. Phila.: Porter \& Coates, (1868.)

NORRIS (THAD.) American Angler's Book. 80 Engravings. 8 vo. Phila.: Porter \& Coates, N. D.

* Memorial Edition with a fine portrait of the Author.

[NORTH (Hon. ROGER).] A Discourse of Fish and Fish Ponds. Done by A Person of Honour. 16mo. London: Printed for E. Curle, 1713.

NORTH (Hon. ROGER). A Discourse of Fish and Fish Ponds. 4to. N. P., N. D.

NORTH-COUNTRY ANGLER, (The); or, The Art of Angling as Practised in the Northern Counties of England. Frontispiece of a Fish. First Edition. 16mo. London: Printed for the Editor; AND SOLD BY J. Richardson, 1786.

NORTH-COUNTRY ANGLER. Vig. 12mo. London: LoNGMaN, 1817.

NORTH-COUNTRY ANGLERS. A Collection of Right Merrie Garlands for North Country Anglers. Illustrations by Bewick. 12 mo. New Castle: Printed for Emerron Charnlex, 1842.

NORTHRUP (A. JUDD). Camps and Tramps in The Adirondacks. 16mo. Syracuse, N. Y.: Davis, BardeEN \& Co., 1880.

NORTH WOODS WALTON CLUB. 12mo. Utica : CuRtiss \& White, Printers. N. D.

NOTICE HISTORIQUE sur L'Etablissement De Pisciculture De Huningue. 4to. Strasbourg: 1862.

NOTIZIE DEI PESCI Delle Provincie Di como E Sondrio E del Cantone Ticino. Seconda Edizione. 16mo. Como: 1864. 
Norfoll( The) Jour. Fiftt Edition. 120 Norwich R. BeaTuiffe, 1495 
Olai Magni. Histôria rerum septêntrionalium, 320 Antarerpicie. Apud Loannom Bellerum 1555. 
NOVA SCO'TIA. List of the Fishes of. Corrected to date, 1879. By J. Matthew Jones. 8vo. N. P.: N. D.

NOVICE. The Anglican Friar and the Fish He Took. By A. Novice, A. F. \& F. Illustrated. 12mo. London: J. \& A. A. Darling, 1851.

$\mathbf{0}$ 'BRIEN (A. H.) Ortario Game and Fishing Laws. Fourth Edition. Sq. 16mo. Ottawa: Despatch \& A gencr Co. And Toronto : 1892-99. O'CONNOR (R.) An Introduction to the Field Sports of France. Illustrated. 12mo. London: John Murray. Paris: Stassin et Xavier, 1846.

ODD (The) VOLUME. Illustrated by Two Odd Fellows-Robt. Seymour and Robert Cruikshank. 16mo. London: W. Kind, N. D.

OGDEN ON FLY TYING. Photo-Portrait of the Author, and of Angler's at the Bull Inn, Fairford, and other illustrations. $12 \mathrm{mo.}$ Cheltenham: J. T. Norman, 1879.

OGDEN ON FLY TYING. Illustrated. 12mo. Cheltenham: J. T. NoRMAN, 1879.

OHIO (STATE OF). First Annual Report of the Commissioners of Fisheries. Year Ending Dec., 1873. 8vo. Columbus : 1874.

OHIO. First Annual Report of the Ohio State Fish Commission to the Governor. Years 1875 and 1876. 8vo. Columbus: 1877.

OHIO. Second Annual Report Ohio State Fish Commission. Year 1877. 8vo. Columbus: 1878.

OKE (GEO. C.) A Handy Book of the Game and Fishery Laws. Second Edition. 12mo. London: Butrerworths, 1863.

OLDFELloW (ALFRED). Uncle Nat. Portrait and Woodcuts. $16 \mathrm{mo}$. New York: 1865.

O'NEILL (J. W.) Glimpses of Animated Nature. Descriptions of Fishes, etc. Illustrated. 8vo. Phila.: 1878.

ONGARO (ANTONIO). Alceo Favola Pescatoria Di Antonio Ongaro. Nuova Edizione Dedicata All' Illustrissima Signora Madama Elisabetta Griffith Lady Rich. 24mo. Londra: Appesso Tommaso Eduin, 1737. OPPIAN. HALIEUTIKA. De Natura Seu Venatione piscium lib. V. [Gr.] Florentiæ in ædibus Ph. Juntæ, 1515. ff. 64. $16 \mathrm{mo}$.

OPPIAN. De Piscibus, L. Lippio interprete, lib. V. [Greek and Latin]. Venetiis. 24mo. In Aidibus Aldi et Andrea Socerr, 1517.

OPPIAN. De Venatione lib. IV., depiscatu lib. V. Cum Interpretatione Latina et Commentariis Studis et Opera Conr. Rittershusii. [Gr. and Lat.] 16mo. Lugd. Bat.: 1597. 

PAGE (I. E.) Angling Days and an Angler's Books, by Jonathan Dale. Illustrated. Cheaper Edition. 12mo. London: E. Sтоok, 1898.

PAIJKULI, (C. W.) A Summer in Iceland. Trans. by Rev. M. R. Barnard. 1llustrated. 8vo. London: Chapman \& Hali, 1868.

PARLOA (Miss M.) Camp Cookery. 24mo. Boston: Estes \& LaurIA'T, (1878).

PARTHENII (NICOLAI). Grannettasii Neapolit Soc. Jesu. Piscatoria et Nautica. Editio Altera. Fine Engravings. 16no. Neapoli : Typis Reais, 1686.

PASKE (Deputy Surg.-Gen'L. C. 'T.) and Aflalo (Fred'k G.) The Sea and the Rod. Illustrated. 12mo. London: Chapman \& Hall, 1892.

PATTERSON (JAS.) A Treatise on the Fishery Iaws of the United Kingdom. 12mo. London and Cambridge: Macmllan, 1863.

PATTERSON (JAMES). Judgment regarding Lord Lonsdale's Salmon Hall Fishery. 8vo. London: Exre \& Spotriswood, (1869).

PATON (Dr. NOEL, EDITOR). Investigations on the Life-History of the Salmon in Fresh Water. Illustrated. 8vo. Glasgow: J $\mathrm{J}_{\mathbf{s}}$. HeDderwick \& Sons, 1898.

PAULIN (M. G.) Nouveau Manuel Complet Du Pêcheur. D'Eau Douce Et De Mer. New Edition. Vignettes, etc. 16mo. Paris : RORET, 1864.

PAYNE-GALLWEY (Sir RALPH, BART.) The Diary of Col. Peter Hawker. Illustrated. 2 vols. 8vo. London and New York: LovaMANS, 1893.

PEACHAM (HENRY). The Compleat Gentleman. Engraved Title by Er. Delaram, and Coats of Arms, etc, Third Impression. Sq. 12mo. London: Printed by E. Tyler for Rich'd Thrale, 1661.

PEARD (WM.) A Year of Liberty. Map. 12mo. London: H. Cox. 1867.

PEARD (WM.) Practical Water-Farming. 16mo. Edinburgh : EDMoNSTON \& Dovglas, 1868.

PEARSON (EDWIN). Anglers' Garland for 1870. Woodcuts by $\boldsymbol{T}$. Bewick. Sq. 8vo. Westminster: Edwin Pearson, 1870.

PEARSON (EDWIN). Angler's' Garland for 1871. Woodcuts by $T$. Bewick. Sq. 8vo. Westminster: Bickers \& Son, 1871.

PEEK (HEDLEY). The Poetry of Sport. 1llustrated. Sq. 8vo. London: Longmans, 1896.

* Badminton Library. Large Paper. 
PEEL (E. LENNOX). A Highland Gathering. 31 Illustrations. $12 \mathrm{mo.}$ London: Longmans, 1885.

PELL (ROBERT L.) Edible Fishes of New York. 8vo. N. P., N. D. [PENN (RICHARD).] Maxims and Hints for an Angler. Drawings on Stone. First Edition. 16mo. London: John Murray, 1833.

PENN (RICH'D.) Maxims and Hints for an Angler. Woodcuts. A New Edition, (Second). 16mo. London: J. Murray, 1839.

PENN (RICH'D) Maxims and Hints for an Angler. Woodcuts. A New Edition. 16mo. London: J. Mulray, 1842.

[PENN (RICH'D).] Maxims and Hints for an Angler. Humorous Engravings. First American Edition. 16mo. Phila.: F. Bell, 1855.

[PENN (RICH'D).] Maxims and Hints for an Angler. Humorous Engravings. 16mo. Phila.: Claxton, Reusen \& Haffelfinger, 1868.

PENNANT (THOS.) British Zoology. (Fish in Vol. III.) Illustrated. 4 vols. 4to. Warrington: Printed by WM. Erres, 1776.

PENNELL (H. C.) Spinning Tackle. With a few words on FineFishing. 16mo. London: HARrison, 1862.

PENNELL (H. C.) Spinning Tackle. Second Edition. 16mo. London: Harrison, 1862.

PENNELL (H. C.) The Angler-Naturalist. 150 Wood Engravings. 12mo. London: J. VAN Voorst, 1863.

PENNELL (H. C.) The Angler-Naturalist. 150 Wood Engravings. 12mo. London and New York : Rodtledge, N. D.

PENNELL (H. C.) The Fisherman's Magazine and Review. Illustrated. 2 vols. 8vo. London: Chapman \& Hall, 1864-1865.

PENNELL (H. C.) The Book of the Pike. Illustrated. $12 \mathrm{mo.}$ London: R. HARDWICKE, 1865.

PENNELL (H. C.) The Book of the Pike. Illustrated. Second Edition. 12mo. London: F. W ARNE \& Co., N. D.

PENNELL (H. C.) The Book of the Pike. Illustrated. Third Edition. 12mo. London: Rovtledege, N. D.

PENNELL (H. C.) Fishing Gossip, Front and Vignette. 12 mo. Edinburgh : A. \& C. Black, 1866.

PENNELL (H. C.) The Modern Practical Angler. Fifty Engravings. Front. of Colored Filies. 12mo. London: F. W ARNE \& Co., 1870.

PENNELL (H. C.) The Modern Practical Angler. Fifty Engravings. 12mo. London: Routledae, N. D. 


PENNELL (H. C.) Fly-Fishing and Worm-Fishing for Salmon, Trout and Grayling. Illustrated. 12mo. London: RootLedge, N. D. (1876).

PENNELL (H. C.) Trolling for Pike, Salmon and Trout. Illustrated. 12mo. London: Routledae, N. D. (1876).

PENNELL (H. C.) Fishing. Salmon and Tront, Pike and Other Coarse Fish. Illustrated. 2 vols. Sq. 8vo. London: Longmans, 1885.

* Badminton Library. Large Paper.

PENNELL (H. C.) The Sporting Fish of Great Britian. 16 Lithographs of Fish in Gold, Silver and Colors. 8vo. London: SAMPson Low, 1886.

PENNELL (H.C.) Fishing. Salmon and Trout, Pike and Other Coarse Fish. Fifth Edition Revised. With Numerous Additional Illustrations. 2 vols. $12 \mathrm{mo}$. London: Longmans, 1889.

* Badminton Library. (2nd vol. Boston and London, 1885.)

PENNELL (H.C.) Modern Improvements in Fishing Tackle and Fish Hooks. 250 Wood Engravings. 12mo. London: SAMPson Low, N. D.

PENNELL. Directions for Making Pennell's Flies, etc. Manuscript of seventeen pages. Sq. 8 ro. N. P.: N. D.

PENNSYLVANIA (STATE OF). Report Comrs. for Restoration of the Fisheries of the Susquehanna, Year 1868. 8vo. Harrisburg: 1869. PENNSYLVANIA. Report of the Comr. for the Restoration of the Inland Fisheries, Year 1870. 8vo. Harrisburg: 1871.

PENNSYLVANIA. Report of the Comr. for the Restoration of the Inland Fisheries, Year 1871 (Including Report on Fish Ladders). 8vo. Harrisburg: 1872.

PENNSYLVANIA. Report of the State Comrs. of Fisheries, Year 1873. 8vo. Harrisburg: 1874.

PENNSYLVANIA. Report State Comrs. Fisheries, Year 1874. 8vo. Harrisburg: 1875.

PENNSYLVANIA. Report of the State Comrs. of Fisheries, Year 1876. 8vo. Harrisburg: B. F. Meyers, 1877.

PENNSYLVANIA. Report of the State Comrs. of Fisheries, Years 1879 and 1880. 8vo. Harrisburg: 1881.

PENNSYLVANIA. Report State Comrs. of Fisheries, Years 1881 and 1882. 8vo. Harrisburg: 1883.

PENNSYLVANIA. Report of the State Comrs. of Fisheries, Years 1883 and 1884. Illustrations. 8vo. Harrisburg: 1885.

PENNSYLVANIA. Report of the State Comrs. of Fisheries, Years 1885 and 1886. Illustrated. 8vo. Harrisburg: 1887. 
PENNSYLVANIA. Report of the State Comrs. of Fisheries, for the Year 1896. Colored Plates. 8vo. N. P.: C. M. Busch, 1897.

PENNSYLVANIA RAILROAD. A Paradise for Gunners and Anglers. Illustrated. Sq. 12mo. Phila.: 1883.

PERCY (SHOLTO and REUBEN). The Percy Anecdotes. Pastime. ("Salmon Hunting," etc.) 24mo. London: T. Boys, 1821.

PERLEY (M. H.) The Fisheries of the Gulf of St. Lawrence. 4to. Fredericton : 1849.

PERLEY (M. H.) Sea and River Fisheries of New Brunswick. 8vo. Fredericton: J. Simpson, 1850.

PERLEY (M. H.) Catalogue [in part] of the Fishes of New Brunswick and Nova Scotia. 8vo. Fredericton: J. Srmpson, $185 \mathrm{~L}$.

PERLEY (M. H.) The Sea and River Fisheries of New Brunswick. Second Edition. 8vo. Fredericton: J. Srmpson, 1852.

PERLEY (M. H.) A Hand-Book of Information for Emigrants to New Brunswick. Map. 12mo. St. John, N. B.: H. Сновв \& Co., 1854.

PERLEY (M. H.) A Hand-Book to New Brunswick. 12mo. London : E. StANFoRd, 1857.

PESCADOR (MARTIN). Piscatorial Patches. 12mo. London: F. V. White \& Co., 1897.

PETIT (G. ALBERT). La Truite de Riviére Peche a la Mouche Artificielle. Illustrations. 8vo. Paris: 1897.

PHILLIPS (HENRY). The True Enjoyment of Angling. Portrait and Music. 12mo. London: W. Pickering, 1843.

PHILLIPS-WOLLEY (CLIVE). A Sportsman's Eden. 8vo. London: R. Bentley \& Son, 1888.

PHILLPOTTS (EDEN). Folly and Fresh Air. 12mo. New York: HARPERS, 1892.

PHIPSON (EMMA). The Animal Love of Shakespeare's Time. Front. 12mo. London: Kegan Paud, 1883.

PIERCE (S. S. CO.,) Sportsmen's Special Limited. Illustrated. Narrow 8vo. Boston: S. S. Pierce Co., N. D.

PIGOREAU (C. B.) Nouveau Traite de la Pêche dan les Fleures et Riviére Navigables. Revu et Augmenté du Vade-Mecum du Pêcheur etc., Par C. Kresz Ainé. 16mo. Paris : 1828.

PINCKNEY (FRANK S.) The Tarpon or Silver King. Map and Illustration. 16mo. New York: Anglers Peblishing Co., 1888.

PISCATOR. Observations on the Public Right of Fishing by Angle or Net, in Thames, etc. 8vo. Marlow: For the Author, 1826. 


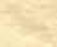

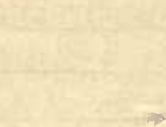


Portiy of The zear. Mnstrative of The Seusous. 16 Chrowe lichograples fiom Dpravisigo 4: Lowou Ciriffin th. n? 
PISCATOR. Handy Guide to the Fishing in the Neighborhood of Bath. 12mo. Bath.: WM. Lewis \& Sons, N. D. (1886).

PIZZETTA (JULES). La Pisciculture Fluviale et Maritime en France. Culture de L'Ecrevisse et des saugsues. Illustrated. 16mo. Paris : 1880.

PLAN FOR THE ENCOURAGEMENT OF THE BRITISH FISHERIES, \&o. 4to. Brunswick and London: J. Budd, 1803.

PLANT SYSTEM. Rod and Gun on the West Coast of Florida. Illustrated. 12 mo. N. P.: N. D.

PLANVERNAY (B. DE). La Pêche A la Ligne. Au Lac du Bourget. 24mo. Aix-Les-Bains: G. Bernard, 1898.

PLATTS (W. CARTER). Angling Done Here. 12mo. London: JARROLD \& SoNs, 1897.

PLATTS (W. CARTER). A Few Smiles. Illustrated. 12mo. London: JARROLD \& Sons, 1898.

POEMS. A Collection of Original Poems by Scotch Gentlemen. $16 \mathrm{mo}$. Edinburgh : A. Donaldson, 1762.

POEY (FELIPE). Conspectus Piscium Cubensium. 4to. Habana : 1861. *Extract from "Historie Natural de la Isla de Cuba."

POITEVIN (M. B.) L'Ami du Pêcheur. Traite Pratique de la Pêche a Toutes Lignes. Avec 98 gravures et 4 planches hors texte. 8vo. Paris : G. MAsson, Editeur, 1873.

POITEVIN (M. B.) L'Ami du Pêcheur. Traité Pratique de la Pêche a Toutes Lignes. Sixieme Edition. With 98 engravings in text and four full page. 12mo. Paris: N. D.

POLLARD (RICHARD). The New and Complete Angler. Cuts of Fish. 16mo. London: Alex. Hoga, N. D.

POLLOCK (FREDERICK). The Fishery Laws. 8vo. London: Wм. Clowes \& Sons, 1883.

POLLOCK (Coloner). Incidents of Foreign Sport and Travel. Illustrated. 8vo. London: Chapman \& Hall, 1894.

[POND (FRED. EUGENE).] Wildwood's Magazine, An Illustrated Monthly of Out-Door Recreation. 8vo. Chicago : May-Oct. 1888.

POND (FRED. E.) The Sportsman's Directory compiled by Will Wildwood [F. E. Pond]. Portrait. 8vo. Milwaukee, Wis.: 1891.

POND (FRED. E.) The Sportsman's Directory and Year Book. I llustrated Second Annual Edition. Compiled by Will Wildwood. Porrait. 8vo. Milwaukee, Wis.: Pond \& Goldey, 1892. 
PORTER'S (WM. T.) Spirit of the Times, vols. 1-4. From Sept. 6, 1856, to Aug. 28, 1858 inclusive. Illustrated. 4to. New York: $1856-58$.

PRACTICAL NOTES on the Legislation for the Fisheries of the St. Lawrence. By Publicus. 8vo. Quebec: "Morning Chronicle" OFFICE, 1864.

PRESBYTERIAN. Log of the 9th Annual Cruise of the Second Presbyterian Fishing Club. 12mo. Philadelphia: Allen, Lane \& Sоотт, 1879.

PRICE (MAJ. Sur ROSE LAMBER'T). The Two Americas. Illustrated. 8vo. Philadelphia: J. B. Lippincott Co., 1877.

[PRIME (WM. C.)] Owl Greek Letters. By W. First and Only Edition. 12mo. New York : Baker \& Scrimner, 1848.

[PRIME (WM. C.)] The Old House by the River. First Edition. 12mo. New York: Harpers, 1853.

[PRIME (W. C.)] The Old House by the River. Second Edition. 12mo. New York: Harpers, 1854.

[PRIME (W. C.)] The Old House by the River. Third Edition. 12mo. New York: Harpers, 1859.

[PRIME (W. C.)] Later Years. First Edition. 12mo. New York: HARPERS, 1854.

PRIME (W. C.) I Go A-Fishing. First Edition. 8vo. New York: HARPERS, 1873.

PRIME (W. C.) I Go A-Fishing. First English Edition. $12 \mathrm{mo}$. London: Sampson Low, 1873.

PRIME (W. C., LL.D.) Along New England Roads. 16mo. New York: HaRPERS, (1892).

[PRIME (W. C., LL.D.)] Among the Northern Hills. 16mo. New York: Harpers, 1895.

PRIME (SAMUEL IREN 开US). Under the Trees. 8vo. New York: H

PRITCHARD (W.) Angler's Guide to the Rivers and Lakes of Wales. Maps. First Edition. 12mo. Wrexham: N. D.

PRITT (T. E.) North-Country Flies. Eleven plates of hand-painted Flies, etc. Second Edition. 8vo. London: Sampson Low, 1886.

PRIT' (T. E.) The Book of the Grayling. Three illustrations in Chromo-Lithography. 4to. Lueeds: Goodall \& Suddicx, 1888.

PRITT (T. E.) An Angler's Basket. Portrait. 12mo. Manchester: A. HAYWOOD \& Son, 1896. 
Porta. Soh. Baptestar. Neapolitani llagiaic valuralis. 24\%. Engravedtitle. Seigd. Bat. - tpud. It de vogel 1644 
Pulmaw 9.PR Vade-mecum of thy-Fishing for Irouh. Seconit Elicion - Rewritten threatly Eulangal. 180 Loubovi Longman, $18+6$. 
PROCTER (GEO. H.) The Fisherman's Memorial and Record Book. Illustrated. 8vo. Gloucester: Procter Bros., 1873.

PROCTER BROS. The Fisheries of Gloncester from the First Catch by the English in 1623 to the Centennial Year, 1876. Illustrated. 8vo. Gloucester: 1876.

PROCTER BROS. The Fishorman's Own Book. Illustrated. Gloucester: Procter Bros., N. D. (1882).

PROU'TY (LORENZO). Fish: Their Habits and Haunts. PhotoPortrait. Sq. 8vo. Boston: Cupples, Upham \& Co., 1883.

[PULMaN (G. P. R.)] Rustic Sketches. Being Poems on Angling. By Piscator. First Edition. 16mo. Taunton: 'W. Brsqg, 1842.

PULMAN (G. P. R.) Vade-Mecum of Fly-Fishing for Trout. Illustrated. $16 \mathrm{mo}$. London: Longmans, 1851.

PULMAN (G. P. R.) Rustic Sketches. Being Poems on Angling. Second Edition. 12mo. London: John GraY BeLL, 1853.

PULMAN (GEO. P. R.) The Book of the Axe. Illustrations and $a$ Map. 12mo. London: Longmans, 1854.

[PULMAN (G. P. R.)] Rambles, Roamings and Recollections. By John Trotannot. (pseud.) Portrait. 12mo. London: Lonaman, 1870.

PULMAN (G. P. R.) Rustic Sketches. Being Rhymes and "Skits." Third Edition. Sq. 12mo. London: J. R. Sмiтн, 1871.

PYE (JAMES). The Sportsman's Dictionary. The Fifth Edition. 17 Plates. 4to. London: John Stockdale, 1807.

C. Life in the Adirondacks. By one of the Q. C. 8vo. N. P.: 1876.

QUEBEC. Lake St. John and the New Route to the Far Famed Saguenay. By E. T. D. Chambers, Illustrated. Narrow $8 \mathrm{vo}$. Montreal: Desbarats \& Co., 1898.

QUEBEC and Canadian Game Laws and Customs Regulations. $12 \mathrm{mo.}$ Ottawa: The Mortimer Co., N. D.

$D$ AMsBotTom (ROBERT). The Salmon and its Artificial Propagation. Engraving of Salmon on title. 8vo. London and Manchester, 1854.

RAPPORT. Sur la Pisciculture et la Pêche Fluviales en Angleterre, en Ecosse et en Irlande. Illustrated. 4to. Strasbourg: 1863. 
RAYMOND (REv. OLIVER). The Art of Fishing on the Principle of Avoiding Cruelty. 16mo. London: Longmans, 1866.

REBUS. Official Introduction to Bahamas Fisheries, By Rebus. 8vo. London: W. Clowes \& Sons, 1883.

RECREATION. A Monthly Magazine devoted to everything that the name implies. G. O. Shields (Coquina) Editor and Manager. From Oct., 1894, to June, 1900. Profusely illustrated. 12 vols. in 11. 8vo. New York: 1895-1900.

REGUIS (J. M. F.) Essai sur L'Histoire Naturelle des Vertébratés de la Provence. Illustrated. 4to. Marseille : 1882.

REMY (J.) Guide du Pisciculteur. Recueillis, Rédigés et Publies Par Le Dr. Haxo. 12mo. Paris: 1954.

RENAULD (L. P.) Le Parfait Pêcheur a la Ligne an Filet, etc. Illustrated. 16mo. Paris: 1873.

RENE ET LIERSEL. Traite de la Pêche a la Ligne et au Filet. Illustrated. 12mo. Paris, N. D.

RENNIE (JAMES). Alphabet of Scientific Angling. Illustrated. 16mo. London: WM. OrR, 1833.

RENNIE (JAMES). Alphabet of Angling. Illustrated. Second Edition. 24mo. London: OrR and Smith, 1836.

RENNIE (JAMES). Alphabet of Angling, for the use of Beginners. Illustrated. 16mo. Isondon: H. G. Bons, 1849.

RENOIR (EDMOND). La Pêche Mise a la Portée Tous, etc. Colored and plain illustrations. $12 \mathrm{mo}$. Paris : N. D.

REVOIL (BENEDICT H.) Chasses et Pêches de L'Autre Monde. 16mo. Paris : 1856.

REVOIL (BENEDICT HENRY). Shooting and Fishing in the Rivers, Prairies and Backwoods of North America. 2 vols., $12 \mathrm{mo}$. London: Tinsley Bros., 1865.

REYMOND (LEON). La Pêche Pratique en eau Douce a la Ligne et au Filet. Illustration by Gus. Doré, \&e. 12mo. Paris: 1883.

REYNARDSON (C. T. S. BIRCH). Sports and Anecdotes of Bygone Days. Coloredillustrations. 8vo. London: Chapman \& Hall, 1887.

REYNOLDS (CHAS. B.) Laws of the United States and Canada relating to Game and Fish Seasons. Illustrated. 8vo. New York: Forest and Stream, 1895.

REYNOLDS (J. M. D.) Peter Gott, The Cape Ann Fisherman. Fourth thousand. Front. 12mo. Boston: 1856. 
Rathbun Mary 9: Hoontribution to a kworn ledge of the Freshrater Crabs of Imerica. The Psoudothelphustrae.

80 Walkingtou 1898 


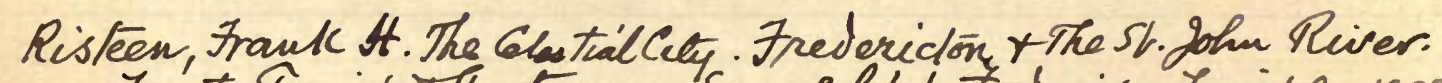

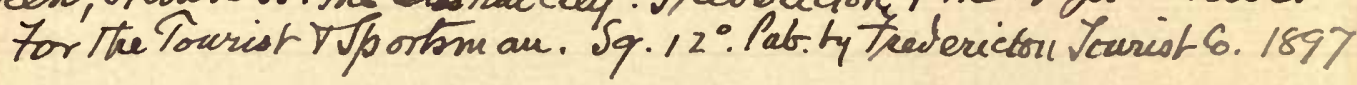


[REYNOLDS (J. H.)] Sporting. Embellished by large engravings and vignettes illustrative of British Field Sports. Edited by Nimrod. Folio. London: A. H. BaILY \& Co., 1838.

RHODE ISLAND (STATE OF). Report on the Fisheries of Narragansett Bay. May session A. D. 1870. 8vo. Pawtucket: 1870.

RHODE ISLAND. Report of the Commissioners of Internal Fisheries. February, 1872. 8vo. Providence: A. C. GreEne, 1872.

RHODE ISLAND. Third Annual Report of the Commissioners of Inland Fisheries. January session, A. D. 1873. 8vo. Providence: Prov. Press Co., 1873.

RHODE ISLAND. Report (17th annual) of the Joint Special Com. mittee to examine into the question of Trap, Fyke and Pound Fishing. January session, A. D. 1887. 8vo. Providence: E. L. Freeman \& SoNs, 1887.

RHODE ISLAND. Twentieth Annual Report Commissioners of Inland Fisheries. January session, 1890. 8vo. Providence: 1890.

RHODE ISLAND. Annual Report (23rd) of the Commissioners of Inland Fisheries. January session, 1893. 8vo. Providence: E. L. Freeman \& Sons, 1893.

RHODE ISLAND. Annual Report (24th) of the Commissioners of Inland Fisheries. January session, 1894. 8vo. Providence: E. I. Freeman \& Sons, 1894.

RHODE ISLAND. Annual Report (25th) of the Commissioners of Inland Iisheries. January session, 1895. 8vo. Providence : E. L. Freeman \& Sons, 1895.

RHODE ISLAND. Twenty-sixth Annual Report of the Commissioners of Inland Fisheries. January session, 1896. 8vo. Providence, R. I. : E. L. Freeman \& Sons, 1896.

RHODE ISLAND. Annual Report (27th) of the Commissioners of Inland Fisheries. January session, 1897. 8vo. Providence: E. L. Freeman \& Sons, 1897.

RHODE ISLAND. Twenty-eighth Annual Report of the Commissioners of Inland Fisheries. January session, 1898. 8vo. Providence : E. L. Freeman \& Sons, 1898.

RHODE ISLAND. Twenty-ninth Annual Report Commissioners of Inland Fisheries. January session, 1899. 8vo. Providence: 1899.

RIOLS (J. DE). Le Parfait Pêchenr a la Ligne au Filet, etc. Illustrated. 16mo. Paris: N. D. 
ROBERTS (Sir RANDAL). The Rivers Side; or, The Tront and Grayling. 16mo. London: H. Cox, 1866.

ROBERTS (Sır RANDAL). Glenmâhra; or, The Western Highlands. Illustrations by the Author. 12mo. London: Chapman \& Hall, 1870.

ROBERTS (SIn RANDAL H.) The Silver Trout and Other Stories. 12mo. London: W. H. Allen \& Co., 1888.

ROBER'TS (T. R.) The Spas of Wales. Illustrated. 12mo. London: JоHN HOGa, N. D.

ROBERTSON (H. R.) Life on the Upper Thanes. Illustrated. 4to. London: Virtue Spalding \& Co., 1875.

ROBERTSON (J. LEITH) Angling Streams and Angling Quarters. Maps. 16mo. Edinburgh: John Menzies, 1859.

ROBERTSON (JOHN). Hand-Book of Angling for Scotland. Map. 16mo. London: HodLston \& Wright, 1861.

ROBERVAL (Tre) Fish and Game Association. Map and Illustrations. Sq. 8vo. New York: Century Publishing Co., N. D.

ROBINSON (PHIL.) Fishes of Fancy. 8vo. London: W. Clowes \& Sons, 1883.

ROBINSON (ROWLAND E.) In New England Fields and Woods. 12mo. Boston and New York: 1899.

ROCKWELL (REv. CHAS.) The Catskill Mountains. Illustrated. 12mo. New York: Taintor Bros., 1867.

ROCKWOOD (CAROLINE W.) In Biscayne Bay. Illustrated by T. A. Hine. 8vo. New York: Dodd, Mesd \& Co., 1891.

RONALDS (ALFRED). Fly-Fisher's Entomology. Illustrated by (19) Colored Representations of the Naturat, and Artificial Insect. First Edition. 8vo. London: Longmans, 1836.

RONALDS (ALFRED). Fly-Fisher's Entomology. Second Edition. With 20 Copperplates (Colored). 8vo. London: Longmans, 1839.

RONALDS (ALFRED). Fly-Fisher's Entomology. Fourth Edition. 20 Colored Plates. 8vo. London: Longmans, 1849.

RONALDS (ALFRED). Fly-Fisher's Entomology. Sixth Edition. 20 Colored Plates. 8vo. London: Longmans, 1862.

RONALDS (ALFRED). Fly-Fisher's Entomology. Ninth Edition. 20 Colored Plates. 8vo. London: Longmans, 1883.

ROOPER (GEO.) Flood, Field and Forest. Fourth Edition. 1llustrated. 16mo. London: W. Issis'rer \& Co., 1874. 
Romanes Geo.f. Animal butelligence. 120 NY. Affleton 1886 

ROOPER (GEO.) A Month in Mayo. 12mo. London: R. HARDWICKE, 1876.

ROOPER (GEO.) The Autobiography of a Salmon. New Edition. Illustration on Cover. 12mo. London: J. S. VIRTUE \& Co., 1886.

ROOPER (GEO.) Thames and Tweed. 12mo. I Iondon and New York: Cassell, N. D.

[ROOSEVELT (ROBER'T BARNWELL)]. Game Fish of the Northern States of America. Illustrated. By Barnwell. First Edition. 12mo. New York: Carleton, 1862.

ROOSEVELT (R. B.) Game Fish of the Northern States and British Provinces. Illustrated. 12mo. New York: CARLETon, 1865.

ROOSEVELT (R. B.) Superior Fishing. Illustrated, 12mo. New York: Carleton, 1865.

ROOSEVELT (R. B.) Game Fish. Illustrated. 12mo. New York: Carleton, 1866.

ROOSEVELT (R. B.) Game Fish. Illustrated. Fourth Edition. 12 mo. New York : CarLeton, 1869.

ROOSEVELT (R. B.) and Green (Seth). Fish Hatching and Fish Catching. 12mo. Rochester, N. Y.: 1879.

ROOSEVELT (R. B.) Superior Fishing. Portrait and Illustrations. 12mo. New York: Orange Judd Co., 1884.

ROOSEVELT (R. B.) Love and Lnck. 16mo, pictured boards. New York: Harpers, 1886.

ROOSEVELT (R. B.) Fertility in Hybridization. 8vo. New York: N. D.

* From Vol. 39, Part II. Proceedings of American Association for the Advancement of Science. Salem : 1885.

RORER (Mrs. S. T.) Fifteen New Ways for Oysters. 24mo. Phila.: Arvold \& Co., (1894).

RORET. Nouveau Manuel Complet du Pêcheur Praticien, etc. Illustrated. 16mo. Paris: 1881.

ROSCOE (E. S.) Rambles with a Fishing-Rod. 16mo. Edin. and London: W. Blackwood \& Sons, 1883.

ROSS (W. A.) A Yacht Voyage to Norway, Denmark and Sweden. Frant. Second Edition. 12mo. London: H. ColBurs, 1849.

ROUTLEDGE'S Handbook of Fishing. Illustrated. 16mo. London: RoJTLEDGe, 1867.

ROWAN (JOHN J.) The Einigrant and Sportsman in Canada. Map. 12mo. London: Edward Stanford, 1876. 
ROXBY (ROBT.) The Lay of the Reedwater Minstrel. Vignette. 12mo. Newcastle: T. \& J. Hodgson, 1832.

RUDDIMAN (THOMAS). A Collection of Scarce, Curious and Valuable Pieces. 16mo. Edinburgh : T. Roddiman \& Co., 1785.

RULES, ORDERS and ORDINANCES for the Fisheries in Thames and Medway. 12mo. London: Arthor Taylor, 1835.

* First Edition.

RURAL ALMANAC and SPORTSMAN'S Illustrated CALENDAR. 4to. N. P.: 1858.

RUSSELL (ALEXANDER). The Salmon. 8vo. Edinburgh : EdmonSTON \& DOJgLAS, 1864.

RUSSELL (ALEX. J.) The Red River Country. Map. 8vo. Ottawa: 1869.

RUST (MARGARET). The Queen of the Fishes. A Fairy Tale of Valois. 12mo. Epping: VAle Press, 1894.

* Strictly limited to 150 copics, of whieh 120 are for sale. No. 114 .

(J.) The True Art of Angling. 24mo. London: PrInted for Onesimus Ustonson, 1770.

SAGE (RUFUS B.) Wild Scenes in Kansas and Nebraska, the Rocky Mountains, etc. Third Edition. Illustrated. 12mo. Phila.: G. D. Miller, 1855.

SABINE (LORENZO). Report on the Principal Fisheries of The American Seas. 8vo. Washington: Robt. Armstrong, 1853.

ST. JOHN (CHAS.) Short Sketches of the Wild Sports and Natural History of the Highlands. 16mo. London: J. Morrar, 1846.

ST. JOHN (CHAS.) A Tour in Sutherlandshire. Woodouts. 2 vols. 12mo. London: J. Murrat, 1849.

ST. JOHN (CHAS.) Short Sketches of the Wild Sports and Natural History of the Highlands. 16mo. London: J. MUrrar, 1849.

ST. JOHN (CHAS.) Sketches of the Wild Sports and Natural History of the Highlands. Illustrated Edition. 12mo. London: J. Murray, 1878.

ST. JOHN (CAPT. H. C.) Notes and Sketches from the Wild Coasts of Nipon. Illustrated. 8vo. Edin.: David Douglas, 1880.

ST. JOHN (HON. FERDINAND). Rámbles in Germany, France, Italy and Russia, in Search of Sport. Colored plates. 12mu. London: Longmans, 1853. 


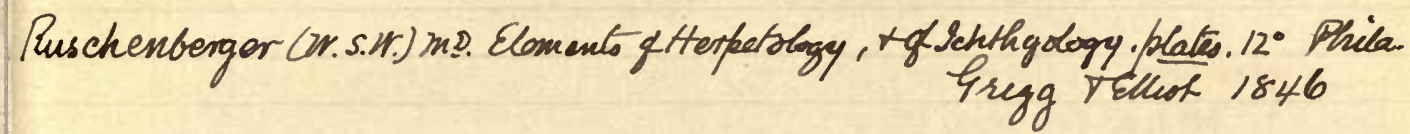

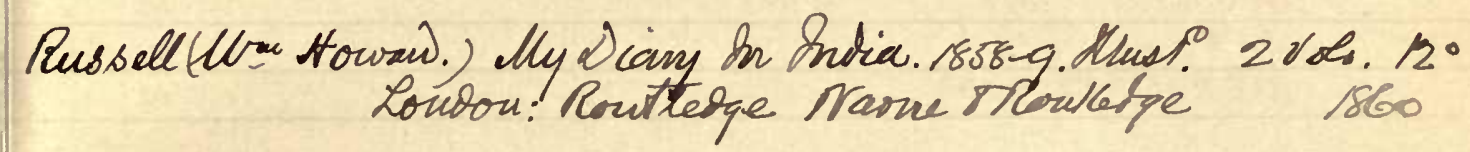


Salmon Fisheries. Report 20 'tolly 18 yo Doncaster: E. White, hi. 
ST. LOUIS AND SAN FRANCISCO R. R. Feathers and Fins on the Frisco. Illustrated. 12mo. St. Louis: 1898.

SALA (GEO. AUG.) Echoes of The Year Eighteen Hundred and EightyThree. Portrait. 8vo. London: Remington \& Co., 1884.

SALIS (MRS. DE). Oysters À La Mode, or The Oyster and Over 100 Ways of Cooking It. 16mo. London : Longmans, 1888.

SALMON FISHING. Drawn and Lithographed by R. O. C. Oblong 4to. London: Published by R. \& A. Ackerman, (1867).

[SALTER (ROBER'T).] The Modern Angler, etc. In a Series of Letters to a Friend. Frontispiece. First Edition. 24mo. Owestry: Printed For the Author by J. Salter, N. D.

SALTER (ROBERT). 'The Modern Angler, in a Series of Letters. Frontispiece. Second Edition. 16mo. Owestry: Printed for the A tThor by W. Edwards, 1811.

SALTER (T. F.) Angler's Guide. Second Edition. Engravings. 8vo. London: For the Author, 1815.

SALTER ('T. F.) The Angler's Guide, Being a Complete Practical Treatise on Angling, etc. Illustrated. Third Edition. 8vo. London : Printed for the Author, 1815.

SALTER ('T. F.) The Angler's Guide. With 25 Engravings and Cuts. Third Edition. 16mo. London: Sherwood, Jones \& Co., N. D.

SALTER ('l'. F.) Angler's Guide. Fourth Edition. Engravings. $16 \mathrm{mo.}$ London: For the AUTHOR, 1816.

SALTER (T. F.) Angler's Guide. Fifth Edition. Engravings. $12 \mathrm{mo}$. London, For the Author, N. D. (1823.)

SALTER ('T. F.) Angler's Guide. Sixth Edition. Engravings. $12 \mathrm{mo}$. London: SHERwoon \& Co., 1825,

SALTER (T. F.) Angler's Guide. Sixth Edition. Engravings. 8vo. London: Sherwood \& Co., 1825.

* Large Paper.

SALTER (T. F.) Angler's Guide. Seventh Edition. 88 fine cuts. $12 \mathrm{mo.}$ London : JoHN Wicksteed, 1830.

SALTER (T. F.) Angler's Guide. Eighth Edition. 88 fine cuts (new engraved title). 12mo. Isondon: JoHN WICKSTEED, 1833.

SALTER ('T. F.) Angler's Guide. Ninth Edition. 88 cuts. $12 \mathrm{mo.}$ London: JAs. MAYNARD, 1841.

SALTER (T. F.) Troller's Guide, Illustrated. First Edition. $12 \mathrm{mo.}$ London: Carpenter \& Son, 1820. 
SALTER (T. F.) Troller's Guide. 28 cuts. Third Edition. 12 mo. London: JAs. MaYNARD, 1841.

SAMUELS (EDWARD A.) With Fly-Rod and Camera. 150 plates. Sq. 8vo. New York: Forest and Stream, 1890.

SANDEMAN (FRASER). By Hook and By Crook. Illustrated. Sq. 12mo. London: Henry Sotheran \& Co., 1892.

SANDEMAN (FRASFR). By Hook and by Crook. Illustrated. 4 to. London: Sotheran \& Co., 1892.

*Only 100 copies printed. No. 32 .

SANDEMAN (FRASER). Angling Travels in Norway. Illustrated, and colored Salmon Flies by the Author. 8vo. London: Chapman \& $\mathrm{H}_{\mathrm{ALL}}, 1895$.

SANDEMAN (FRASER). Angling Travels in Norway. Illustrated. 4to. London: Chapman \& Hali, 1895.

SANDERS (J. MILTON). The Crystal Sphere. Reflections on a Drop of Water. Colored Front. Sq. 16mo. London: Hippolyte BaILLIERE, 1857.

SANNAZARO (JACOPO). Opera Omnia Latine Scripta. 16mo. Venetiis, in cedibus horedum A. Manutii, 1535.

SAN'TE FE ROUTE. A Colorado Summer. Illustrated. Sq. 8vo. Chicago: Corbett \& Butterfield Co., 1898.

[SAUNDERS (FREDERI(YK).] Salad for the Solitary and the Social. By an Epicure. 52 Original designs by Am. Artists. Engraved by Bobbett \& Matthews. Sq. 8vo. New York: De Witt C. Lent \& Co., 1872.

SAUNDERS (FREDERICK). The Story of some Famous Books. Sq. 8vo. London : Elliot Stock, 1887.

* Large paper copy. The Book Lover's Library. Edited by Henry B. Wheatley, F. S. A.

SAUNDERS (JAMES). The Compleat Fisherman. Collected from the Best Authors. Folded frontispiece. 16mo. London: Printed for W. Mears and S. Tooke, 1724.

SAUVAGE (DR. H. E.) La Grande Pêche les Poissons. fir Illustrations. 12mo. Tours: 1890 .

SAUVAGE (H. E.) AND D'HERCULAIS (J. K.) Les Poissons et les Crustaces Edition Francais. Numerous plates. 4to. Paris: J. B. Baldiere et Fils, N. D.

SCAMMON (CHARLES M.) Marine Mamimals of the N. W. Coast of N. America, with an account of American Whale-Fishery. Illustrated. 4to. San Francisco: 1874 . 


SCHOMBURGK (ROBT. H.) Natural History of The Fishes of Guiana. 66 colored plates. 2 vols. First Edition. 16mo. Edin.: W. H. Lizars, 1841.

SCHOOL OF WISDOM ; or, Repository of the most Valuable Curiosities of Art and Nature. 16mo. Gainsbrough : Printed by Joun MoseLEX, 1776.

SCHOOLCRAFT (HENRY R.) Narrative of an Expedition through the Upper Mississippi and Itasca Lake in 1832. Map. 8vo. New York: Harpers, 1834.

SCHREINER (WM. H.) Sporting Mannal. Fishing, Fowling and Hunting. Illustrated. 16mo. Phila.: 1841.

SCHULTES (HENRY). An Essay on Aquatic Rights. Law relative to Fishing. 8vo. London: W. Clarke \& Sons, 1811.

SCHWATKA (FREDERICK). Nimrod in the North. Hunting and Fishing adventures in the Arctic Regions. Sq. 8vo. New York: Cassell Publishina Co., (1892).

SCHWATKA (FRED'K.) A Summer in Alaska. Illustrated. 8vo. St. Louis, Mo.: J. W. Henry, 1893.

SCHWATKA (FREDERICK). Along Alaska's Great River. Illustrated. 8vo. Chicago: Henry Publishing Co., 1898.

SCORESBY (W., JUN.) An account of the Arctic Regions, with a history and description of the Northern Whale-Fishery. 24 engravings. 2 vols. 8vo. Edinburgh: A. Constable \& Co., 1820.

SCOTLAND. The Golfers and Angler's Holiday Guide to Scotland. Illustrated. 12mo. Inverness : 1897.

SCOTT (GENIO C.) Fishing in American Waters. 170 Illustrations. First Edition. 12mo. New York: HarPers, 1869.

SCOTT (GENIO C.) Fishing in American Waters. A New Edition containing parts six and seven. Illustrated. 8vo. New York: American News Co. N. D. (1875).

[SCOT'T (DR. THOMAS).] The Anglers. Eight Dialogues in Verse. 16mo. London : Printed for E. DrLly, 1758.

SCOT'T (WM. HENRY). British Field Sports. Fishing, ete. Illustrated. 8vo. London: Sherwood, NeELy \& JoNes, 1818.

[SCO'TT (WM. HENRY).] The Sportsman's Calendar. By the Author of the British Field Sports. Vig. 16mo. London: SHerwood, Neely \& Jones, 1818.

SCRAP BOOK OF FISH ADVERTISEMENTS. 4to. N. P., N. D. 
SCRAP BOOKS. Fishing scraps. Newspaper clippings on the subject of Fishing and Kindred subjects mounted in $3 \mathrm{Sq}$. 8ro books. 3 vols., N. P., N. D.

SCROPE (WM.) Days and Nights of Salmon Fishing in the Tweed. Illustrated. Second Edition. 8vo. London: John Murray, 1854. SCROPE (WM.) Days and Nights of Salmon Fishing in the River Tweed. Illustrated. 8vo. London and Glasgow: 1885.

SCROPE (WM.) Days and Nights of Salmon Fishing in the River Tweed. Illustrated by Lithographs and Wood Engravings. Plate of two Young Salmon beautifully colored as Frontispiece. Sq. 8vo. London: Edward Arnold, 1898.

SCUDDER (CHAS. W.) List of Publications of the U. S. Fish Commission, 1871-1896. 8vo. Washington : 1896.

[SEARS (GEO. W.)] Woodcraft. By "Nessmuk." Engravings. 16mo. New York: Forest and Stream, (1884).

SEARS (GEO. W., "Nessmuk.") Forest Runes. Portrait. 8vo. New York: Forest and Stream, 1887.

SEASIDE LIBRARY. Fish and Fishing. By Thos. Alexander. Illustrated. Folio. New York: Geo. Munro, 1879.

SEELEY (H. G.) The Fresh Water Fishes of Europe. 214 illustrations. Sq. 8vo. London: Casselds, 1886.

"SENECA." Hints and Points for Sportsmen. Compiled by "Seneca." Illustrated. 16mo. New York: Forest and Stream, 1889.

SENIOR (W.) Waterside Sketches. Front. 12mo. London: Grant $\&$ Co., 1875.

SENIOR (W.) By Stream and Sea. 12mo. London: Chatto \& WinDus, 1877.

SENIOK (W.) Travel and Trout in the Antipodes. Portrait. $12 \mathrm{mo.}$ London : Chatro \& Windes, 1880.

SENIOR (WM.) Angling in Great Britain. 8vo. London: W. Clowes \& Sons, 1883.

SENIOR (WM.) Waterside Sketches. (Cheap Edition.) 24mo. London: SAMpson Low, 1885.

SENIOR (WM.) Near and Far. 12mo. London: SAMPson Low, 1888. SENIOR (WM.) The Thames from Oxford to the Tower. Illustrated with 30 Original Painter's Etchings by F. S. Walker. 4to. London: J. C. Nimmo, 1891.

[SENIOR (W.)] A Mixed Bag. By "Red Spinner." 16mo. London: H. Cox, 1895 . 


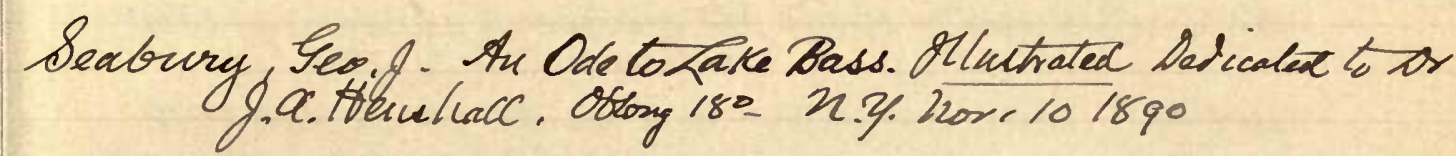


Shaw. (Geo.) Zoological Lectures $1806-18072$ vas 80 Loud on fit for Gev. Kearsley, 1809 . Shields, 9.0. Comping tamp outfits Whet, 12 Chicago my. 
SENIOR (W.) Pike and Perch. With Chapters by "John Bickerdyke" and W. H. Pope. Cookery by Alex. I. Shand. Illustrated. $12 \mathrm{mo.}$ London: Longmans, 1900.

SENIOR (IVM.) By Stream and Sea. A New Edition. 16mo. Lon. don: Chatto \& Windos, N. D.

SEYMIOUR (E. S.) Sketches of Minnesota. Map. 12mo. New York : HARPERS, 1850.

SHAW (GEORGE). General Zoology or Systematic Natural History. Fishes. With plates principally engraved by Wm. Heath. 2 vols., 8vo. London : Printed for G. Krarslet, 1803.

SHAW (JOHN). Development and Growth of Salmon-Fry. Plates. 4to. Edin.: A. \& C. BLACK, 1840.

SHELTON (F. W.) Up the River. Illustrated. 12mo. New York: Chas. Scribner, 1853.

SHEPHERD (RICH'D. HERNE) Waltoniana. Inedited Remains in Verse and Prose of Izaak Walton. 12mo. London: Pickering \& Co., 1878.

SHIELDS (G. O.) Rustlings in the Rockies: Hunting and Fishing. Illustrated. 12mo. Chicago: Belford, Clarke \& Co., 1883.

SHIPLEY (M. A.) Artificial Flies and How to Make Them. Illustrated. 16mo. Phila.: 1888.

SHIPLEY (MALCOLM A.) A Dictionary of Trout and Bass Flies. Oblong 24mo. Phila.: 1898.

SHIPLEY (WM.) A 'True Treatise on the Art of Fly-Fishing, Trolling, etc. Edited by Edward Fitzgibbon. Illustrations. 8vo. London: Simpkin, Marshall \& Co., 1838.

SHIRLEY (THOMAS). The Angler's Museum; or the Whole Art of Float and Fly Fishing. Portrait of John Kirby and cut of fish. 16mo. London: John Fielding, 1784.

[SHIRLEY (THOS.)] The Angler's Museum. Second Edition. Portrait and cut of fish. 16mo. London: JoHn Fielding, N. D.

* The Author's name is left off title and preface in this Edition, and prefixed is "The Sermon of St. Anthony to a Miraculous Congregation of Fishes."

[SHIRLEY (THOS.)] The Angler's Museum. Portrait and cut of fish. Third Edition. 16mo. London: Jonn Fielding, N. D.

SHRUBSOLE (EDGAR S.) Long Casts and Sure Rises. 12mo. London: Remington \& Co., 1893. 
SIM (G.) Food of Fishes, Both in Fresh and Salt Water. 12mo. London: W. Clowes \& Sons, 1884.

* Bound with above: Forest Protection and Tree Culture on Water Frontages; Providing Water, Food, Shade, etc. for Freshwater Fish. By D. Howitz.

SIMEON (CORNWALL). Stray Notes on Fishing and Natural History. Illustrated. 12mo. Cambridge: Maomillan, 1860.

SIMMONDS (P. L.) The Commercial Products of the Sea. 32 Illustrations. 12mo. New York: Appleton \& Co., 1879.

"SIXTY-ONE" Reminiscences of the Lews. By "Sixty-One." Portrait of the Author and Illustrations. Second Edition. 12mo. London: Bickers \& Son, 1873.

SKIOLDEBRAND (A. F.) A Picturesqe Journey to the North Cape. Tinted Engravings. 8vo. London: V. M. RICHardson, 1813.

SLACK (HENRY J.) Marvels of Pond Life. Second Edition. WIth colored plates and wood engravings. 12mo. London: Groombridat $\&$ Sons, 1871.

SLACK (J. H.) Practical Tront Culture. Illustrated. 12mo. New York: Geo. E. Woodw $\triangle$ Rd, 1872.

SLACK (J. H.) Practical Trout Culture. Illustrated. 12mo. New York: American News Co., N. D.

SLATER (J. HERBERT). Illustrated Sporting Books, with an Appendix of Prints Relating to Sports of the Field. 12mo. London: L. U. GiLL, 1899.

SLAUGHTER (FRANCES E.) The Sportswoman's Library. Illustrated. 2 vols. 8vo. Westminster: A. Constable \& Co., 1898.

SLOSSON (ANNIE TRUMBULL). Fishin' Jimmy. Illustrated. 12mo. New York: A. D. F. Randolpir \& Co., (1889.)

SLOSSON (ANNIE TRUMBULL). Fishin' Jimmy. With Illustrations by Alice Barber Stephens. 12mo. New York: Chas. SoribNER's SoNs, 1898.

SMALL (H. BEAUMONT). Animals of North America. Series II. Fresh-Water Fish. 8vo. Montreal: M. Longmore \& Co., 1865.

SMALL (H. B.) Canadian Hand-book and Tourist's Guide. Edited by J. Taylor. Photo-Illustrations. 12mo. Montreal: M. Longmore \& Co., 1866.

SMILES (SAMUEL). Life of a Scotch Naturalist. Portrait and Illustrations. $12 \mathrm{mo}$. New York: Harpers, 1877.

SMITH (ALBERT). Wild Oats and Dead Leaves. 12mo. London: Chapman \& Hall, 1860. 
Small, A. B. The Produets tmainffactaies of the new Dranincion 80. Ottawa: Printase by \&E Desbarals, 1868 
Snith, Augh M. Fishes tound in tho Vicinity of Woods ttele. (Mas) Mep. hupl so Wasliciegtore 1898 . 
SMITH (ARTHUR). The Thames Angler. Illustrated. Second Edition. 12mo. London: Chapman \& Hali, 1860.

S. [MITH] (A. W.) and M. W. H. [ALLE'T]. The Thames Angler. Third Edition. Frontispiece. London: Whitraker \& Co., 1846.

SMITH (GEO. PUTNAM). The Law of Field Sports. 12mo. New York: O. Jubn Co., 1886.

SMITH (HELEN AINSLIE). Birds and Fishes. Nearly 200 Illustrations. 4to. New York and London: (1886).

SMITH (H. PERRY). The Modern Babes in the Woods; or, Summerings the Wilderness. Engravings. 12mo. Hartford: Columbian Bоoк Co., 1872.

SMITH (JEROME V. C.) Natural History of the Fishes of Massachusetts. Illustrated. 12mo. Boston: Allen \& Troknor, 1833.

SMITH (JEROME V. C.) Natural History of the Fishes of Massachusetts. Illustrated. Second Edrtion. 16mo. Boston : 1843.

[SMITH (JOHN).] The True Art of Angling. By J. S., Gent. A Brother of the Angle. Frontispiece. Narrow 32mo. London. Printed for Geo. Conyers, 1696.

[SM1TH (JOHN).] The Compleat Fisher; or, The True Art of Angling. By J. S., A Brother of the Angle. Frontispiece. Fifth Edition. Narrow 32mo. London: Printed for G. Conyers, 1725.

[SMITH (JOHN).] The Compleat Fisher; or, The True Art of Angling. By J. S. A Brother of the Angle. Sixth Edition. Frontispiece. Narrow 32mo. London: Printed for G. Conyers, N. D.

SMI'H (LAURA ALEXANDRINE). The Music of the Waters. Songs set to Music, etc. 8vo. London: Keegan PaUL, 1888.

SMITH (THOMAS). Every Man His Own Fisherman. 32mo. London: Printed for C. Moran, N. D.

SMITH (Rev. THOS.) Naturalist's Cabinet (Vol. 5 containing the part relating to Fishes, \&c.) Fine Engravings. 16mo. Albion Press Printed. Published by James Cundex. N. P.: 1807.

SMITH (WM.) Official Paper on the Fisheries of Canada. 8vo. Chicago : WORLD's FAIR, 1893.

SMITH (W. ANDERSON). Benderloch; or, Notes from the West Highlands. 12mo. Paisley: Alex. Gardner, 1882.

"SNAFFLE." Gun, Rifle and Hound, in East and West. Illustrated by H. Dixon. 8vo. London: Chapman \& Halt, 1894. 
[SNART (CHAS.)] Practical Observations on Angling, in the River Trent. By a Resident in the Neighbourhood. 16mo. Newark: S. and I. RIDGE, 1801.

[SNART (CHAS.)] Selection of Poems. 2 vols. First Edition. $12 \mathrm{mo}$. Newark : M. HAGE, 1807.

SNAR'T (R.) Elegant Extracts in Verse. 2 vols. Several Poems on Angling, etc. 12mo. Newark: M. HAGE, 1813.

SNELL (F. J.) The Country of the Wild Red Deer. Illustrated. $12 \mathrm{mo.}$ Dulverton: B. BAYLEY, 1900.

SOLTAU (G. W.) Trout Flies of Devon \& Cornwall. Colored Plates of Flies. 12mo. London : Longman \& Co., 1847.

SONGS OF 'THE CHACE, ETC. Second Edition. Frontispiece. $16 \mathrm{mo}$. London: Sherwood, Neely \& Jones, 1811.

SONNENSCHEIN (WM. SWAN). A Bibliography of Arts, Trades and Sports. 4to. London': 1897.

SOUTHERN RAILWAY CO. Shooting and Fishing in the South. Illustrated. Sq. 8vo. New York: Frank Presbrey, 1898.

SOUTHERN RAILWAY. Hunting and Fishing in the South. Illustrated. Sq. 8vo. Washington: W. A. TuRk, (1900).

SPANGLER (A. M.) "Near By," Fresh and Salt Water Fishing. Map and Illustratiors. Sq. 12mo. Phila.: 1889.

SPEEDY (THOS.) Sport in the Higlilands and Lowlands of Scotland, with Rod and Gun. Illustrated. 8vo. Edin. and London: W. Black WOoD \& Sons, 1884.

SPEEDY (TOM). Sport in the Highlands and Lowlands of Scotland. Illustrated. Second Edition. 8vo. Edin. and London: W. BlackWOOD \& SoNs, 1886.

SPENDER (EDW ARD). Fjord, Isle and Tor. Front. 12mo. London : Charlton Tucker, 1870.

SPOR'T. The Encyclopædia of Sport. Edited by the Earl of Suffolk and Berkshire, Hedley Peek and F. G. Aflalo. Illustrated. 2 vols. 4to. London: Lawrence \& Bullen, 1897.

SPORT. The Encyclopædia of Sport. Edited by the Earl of Suffolk and Berkshire, Hedley Peek and F. G. Aflalo. Illustrated. 2 vols. 4to. New York and London: G. P. Putnam's Sons, 1898.

SPORTING ALMANAC, 1839. 12 Engravings. 16mo. London : F. Churton, 1839.

SPOR'IING ALMANAC and Oracle of Rural Life for 1842. 12 Illustrations, Fourth Year. 16mo. London: A. H. BAlLY \& Co., 1842. 

Another Edm 1790 
SPORTS. A New Book of Sports. Reprinted from the Saturday Review. 12mo. London: R. Bentley, 1885.

SPORTS. The Old Sports of England. 24mo. London : Cuas. Knight, 1835.

SPORTSMAN'S DICTIONARY ; or, the Gentleman's Companion, for Town and Country. Copper Plates. 4to. London: Fielding \& W ALKER, 1778.

SPORTSMAN'S POR'TFOLIO OF AMERICAN FIELD SPOR'TS. 1llustrated. Oblong 8vo. Boston : M. M. Ballou, 1855.

STACY-WATSON (C.) The Silvery Hosts of the North Sea. Illustrated. 12mo. London: "Home Words" OfFioe, N.D.

STARK (JOHN). Elements of Natural History. Illustrated. 2 vols. 8vo. Edinburgh : 1828.

STEELE (SIR RICHARD). An Account of the Fish-Pool. By Sir Richard Steele and Mr. Joseph Gillmore. Portrait Inserted and Cuts. 8vo. London: H. MeERe, 1718.

STEELE (THOS. S.) Canoe and Camera. Illustrated. Sq. $12 \mathrm{mo.}$ New York: Orange Judd Co., 1880.

STEELE (THOS. SEDGWICK). Paddle and Portage from Moosehead Eake to the Aristook River, Maine. Over 60 Illustrations. 8vo. Boston: Estes \& Ladriat, 1882.

STEVENS (CHAS. W.) Fly-Fishing in Maine Lakes. 24mo. Boston : Frankitn Press, 1881.

STEVENS (CHAS. W.) Fly-Fishing in Maine Lakes. Illustrated. 16mo. Boston: Cupples, Upham \& Co., 1884.

STEVENS (WILLIAM). How to Angle; including Trolling and Spinning. Engraving. 24mo. London: W. Stevens, Family Herald OfFice, N. D.

* Issued as "Family Herald Handy Book." No. VIII.

STEVENSON (ROBERT LOUIS). The Graver and the Pen. Illustrated. 24mo. Edinburgh : S. L. Osborne \& Co., N. D.

"Fac-simile Edition. Contains Poem "The Angler and The Clown."

S'TEVENSON (WM., M.D.) Original Poems on Several Subjects. 2 vols. 16mo. Edinburgh: A. Donaldson, 1765.

STEWART (W. C.) The Practical Angler. First Edition. 16mo. Edinburgh: A. \& C. Black, 1857.

STEWART (W. C.) The Practical Angler. Second Edition. $16 \mathrm{mo.}$ Edinburgh : A. \& C. Black, 1857. 
STEWART (W. C.) The Practical Angler. Third Edition. $16 \mathrm{mo}$. Edinburgh : A. \& C. BLACK, 1857.

STEWART (W. C.) The Practical Angler. Fourth Edition. $16 \mathrm{mo}$. Edinburgh : A. \& C. BLACK, 1861.

STEWART (W. C.) The Practical Angler. Fifth Edition. $16 \mathrm{mo}$. Edinburgh : A. \& C. Black, 1867.

STEWAR'T (W. C.) A Caution to Anglers. 16mo. Edinburgh: A. \& C. BLACK, 1871.

STIRLING (J.) The Propagation of the Salmonidæ. [Prize Essay.] 8ro. London: W. Clowes \& Sons, 1884.

* Other Essays in same cover by T. Andrews, W. O. Chambers, and Sir J. R. G. Maitland.

STODDARD (S. R.) The Adirondacks. Illustrated. 12mo. Albany : Weed, Parsons \& Co., 1874.

STODDART (THOS. TOD). The Art of Angling as Practised in Scotland. Illustrated. First Edition. 16mo. Edinburgh: W. \& R. Chambers, 1835.

STODDART (THOS. TOD). The Art of Angling as Practised in Scotland. Illustrated. Second Edition. 16mo. Edinburgh: W.\& R. Chambers, 1836.

STODDART (THOS. TOD). Angling Reminiscences. Illustrated. 16mo. Edinburgh: Edin. Printing \& Publishing Co., 1837.

STODDART (THOS. TOD). Songs and Poems. In Three Parts. 8 vo. Edinburgh : W. Blackwood \& Sons, 1839.

STODDART (THOS. TOD). Angler's Companion to the Rivers and Lochs of Scotland. Front. First Edition. 12mo. Edinburgh and London: W. Blackwood \& Sons, 1847.

STODDART (THOS. TOD). Angling Reminiscences. Illustrations. 16mo. London : Re-Published by Henry Washbourne, 1848.

STODDART (THOS. TOD). Angler's Companion to the Rivers and Lochs of Scotland. Front. Second Edition. 12mo. Edinburgh and London: W. BLackwood \& Sons, 1853.

STODDART (THOS. TOD). An Angler's Rambles and Angling Songs. Vignette. 12mo. Edinburgh: Edmonston \& Douglas, 1866.

STODDART (THOS. TOD). Angling Reminiscences of the Rivers and Lochs of Scotland. 12mo. London and Glasgow : 1887.

STODDAR' (THOS. TOD). Angling Songs. Memoir by Anna M. Stoddart. Portrait. 12mo. Edinburgh and London: W. BlackWOOD \& Sons, 1889. 
Stoddard (4m os The baptain's Boat Hestralde. 80 sloddard, Fen The the The meriam o., (1894) Pub oor the auther 1893 

STODDART (THOS. TOD). Angler's Companion. A Popular and Practical Hand-Book to the Art of Angling. Third Edition. $12 \mathrm{mo}$. London: Simpkin, 1892.

STONE (LIVINGSTON). Domesticated Trout. Illustrated. $16 \mathrm{mo}$. Boston: Jas. R. OsGood \& Co., 1872.

STONE (LIVINGSTUN). Domesticated Trout. Illustrated. Third Edition. 12mo. Charlestown, N. H.: 1877.

STONE (LIVINGSTON). Domesticated Trout. Illustrated. Fourth Edition. 16mo. Charlestown, N. H.: 1891.

STONE (LIVINGSTON). Domesticated Trout. Illustrated. Fourth Edition. 16mo. Charlestown, N. H.: 1896.

STORER (D. HUMPHREYS) and Peabody (Wm. B. O.) Reports on the Fishes, Reptiles and Birds of Massachusetts. Illustrations. 8vo. Boston : Dutron \& Wentworth, 1839.

STORER (D. H.) A Synopsis of the Fishes of North America. 4to. Cambridge : 1846.

STORER (DAVID HUMPHREYS). A History of the Fishes of Massachusetts. Plates. 4to. Cambridge and Boston: 1867.

STREET (ALFRED B.) Poems. Complete Edition. 8vo. New York: Clark \& Austin, 1845.

STREET (ALFRED B.) Woods and Waters; or, The Sanaracs and Racket. Illustrations. 12mo. New York: M. Doolady, 1860.

[STREET (ALFRED B.)] Woods and Waters. \& Illustrations. $12 \mathrm{mo.}$ New York: Hord \& Houghton, 1865.

STREET (ALFRED B.) The Indian Pass. 12mo. New York: Hurd \& Hovghton, 1869.

STREETER (EDWIN W.) Pearls and Pearling Life. Illustrated. 8vo. London: G. Bell \& Sons, 1886.

STRETTON (CHAS.) Sport and Sportsmen. Front. and Engraved Title. 8vo. London: Hurst \& Blaoketr, 1866.

STRICKLAND (MAJor). Twenty-seven Years in Canada West. -2 vols. 12mo. London: R. Bentreey, 1853.

S'TRICKLAND (W. P.) Pioneers of the West. Illustrated. $12 \mathrm{mo.}$

New York: Carlton \& Phillips, (1856).

STRUTT (JOSEPH). Sports and Pastimes of the People of England. Engravings. Second Edition. 4to. London: T. Benslex, 1810.

SUCKLEY (GEO.) On the North American Species of Salmon and Trout. (Written in 1861.) 8vo. (Washington : 1874.) 
SUFFLING (ERNEST R.) The Land of the Broads. Map. $12 \mathrm{mo.}$ London: L. U. GiLL, 1885.

SUFFLING (ERNEST R.) The Land of the Broads. Illustrated Edition with large Colored Map. 12mo. Stratford, Essex : BenJ. FERRY, N. D.

SUMMER SAUN'TERINGS in Northern Wisconsin. Illustrated. 16mo. Milwaukee: Cramer, Aikins \& Cramer: 1881.

SWAINSON (WM.) Natural History and Classification of Fishes, Amphibians and Reptiles. Illustrated. 2 vols. 16mo. London: Longmans, 1838-39.

TANDON (Mons. MOQUIN). The World of the Sea. Translated by Rev. H. M. Hart from "Le Monde de la Mer." Illustrated. 8vo. London: Cassele, N. D.

TAPLIN (WM.) Sporting Dictionary and Rural Repository of General Information. Steel Engravings. 2 vols. 8vo. London: Thos. MaIdeN FOR VERNOR \& HOOD, 1803.

TAYLER (JAS.) Red Palmer. A Practical Treatise on Fly-Fishing. Third Edition. 12mo. Folkestone: T. Kentrield, 1893.

TAYLOR (JOHN). Canadian Hand-Book and Tourist's Guide. Fishing and Shooting. Photo-Illustrations. 12mo. Montreal: M. LonGMOORE \& Co., 1867.

TAYLOR (Dr. J. E.) Half Hours at the Seaside. Illustrated. New Edition. 12mo. London: W. H. Allen \& Co., 1890.

TAYLOR (SAMUEL). Angling in All Its Branches. 12mo. London : LONGMAN, 1880.

TAYIOR (SAMUEL). Angling in All Its Branches. 8vo. London: Longman, 1800.

* Large Paper.

TAUNT (HENRY W.) Map and Guide to the River Thames. Illustrated. Second Edition. Oblong 16mo. Oxford: H. W. TAunt, 1873.

TAUNT'S (H. W.) Map and Guide to the Thames. Pocket Edition. Map of River, etc. Sq. 32mo. Oxford: N. D.

TEATINO (Del P. D. P. C.) Fauna Biblicæ ovvero Spiegazione Degli Animali, Menzionati Nella Sacra Scrittura Opera. Plates. Sq. 8vo. Palermo : 1880.

TENISON-WOODS (REV. J. E.) Fish and Fisheries of New South Wales. Illustrated. Narrow 8vo. Sydney: Thos. Richards, 1883. THALLATA. A Book for the Seaside. First Edition. 12mo. Boston: Tioknor, REed \& Fields, 1853. 


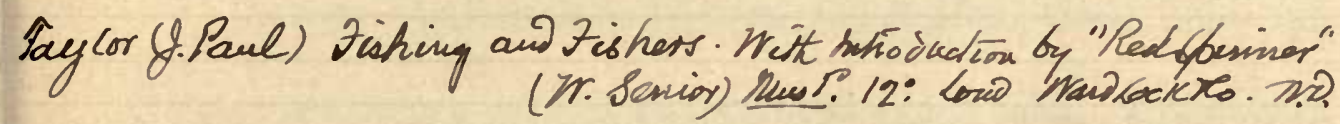



THAMES ANGLING PRESERVATION SOCIETY. 48mo. Twickenham: W. H. Curtis, Printer, 1840.

THAMES ANGLING PRESERV ATION SOCIETY, Established 1838. Annual Report and List of Subscribers for 1863-4. 16mo. London : Printed for the Socie'ly by Arliss \& Co., 1864.

THAMES ANGLING PRESERVA'TION SOCIETY, Instituted 1838. Annual Report and List of Subscribers for 1866-7. 16mo. Burslem: Printed for the Society, 1867.

THAMES ANGLING PRESERVATION SOCIETY. The "Blue Book" of. Useful Information for Thames Anglers. 16mo. Hounslow, Middlesex : Gosden, 1879.

THAMES ANGLING PRESERVATION SOCIETY. The Blue Book of the. The Annual Report, etc. 16mo. London: 1881.

['THEAKSTON (MICHAEL).] A List of Natural Flies that are Taken by Trout, Grayling and Smelt, in the Streams of Ripon. Plates of Colored Flies. First Edition. 16mo. Ripon: W. HARrison, 1853.

['THEAKSTON (MICHAEL).] A List of Natural Flies that are Taken by Trout, Grayling and Smelt, in the Streanıs of Ripon. Illustrated. 16mo. Ripon: W. Harrison, 1853.

[THEAKSTON (MICHAEL).] British Angling Flies. Revised and Annotated by Francis M. Walbran. Illustrated. 12mo. Ripon and London: N. D.

THOMAS (HENRY SULLIVAN). The Rod in India. Illustrations of Fish and Tackle. 8vo. Mangalore: C. Stouz, 1873.

THOMPSON (C. WYVILLE). The Depths of the Sea. Maps and Illustrations. Second Edition. 8vo. London: Macmillan, 1874. THOMPSON (FRANCIS BENJ'N.) Dipple's Hand-books. Angling, etc. Illuslrated. (7 Parts.) 12mo. London: Edwin Dipple, N. D. THOMPSON (GIBSON). Wolfe-Land. A' Hand-book to Westerham. Illustrated. Second Edition, 12mo. Westerham: J. A. Hugres, N. D.

THOMPSON (MAURICE). Boys' Book of Sports. 1llustrated. Sq. 8vo. New York: Cexrury Co., 1896.

THOMPSON (WINFIELD M.) In the Maine Woods. A Guide-Book for Sportsmen. Map and Illustrations. 8vo. Bangor: BANGor \& Aroostook R. R., 1900.

THOMSON (JAMES). The Seasons and Castle of Indolence. Front. and Vig. 24mo. London: C. \& L. Rivington, 1826. 
THOMSON (JAS.) The Value and Importance of the Scottish Fisheries. 12mo. London : Smith, Elder \& Co., 1849.

THOREAU (HENRY D.) Walden; or, Life in the Woods. Vignette. First Edition. 12mo. Boston: Trcknor \& Fields, 1854.

THORNBURY (WALTER). Cross-Country. Front. 12mo. London: SAMPSON Low, 1861.

THORNE (JAMES). Rambles by Rivers. The Thames, Avon, Duddon, etc. Illustrations by the Author. 4 vols. 24mo. London: 1844-1849.

THORNTON (Cor. T.) A Sporting Tour Through the Northern Parts of England and Great Part of the Highlands of Scotland. 16 Engravings. 4to. London: Vernor \& Hood, 1804.

THORPE (CoL. T. B.) The Hive of "The Bee-Hunter." Illustrated. 12mo. New York: D. A Ppleton \& Co., 1854.

THOUSAND (A) Notable Things on Various Subjects, etc. $16 \mathrm{mo}$. London: G. \& T. WILk 1793.

THRASHER (HALSEY). The Hunter and Trapper. Illustrated. 12mo. Orange Judn Co., (1868).

THREE ANGLERS. How to Catch Trout. By Three Anglers. Illustrated. 16mo. Edin.: David Douglas, 1888.

THREE ANGLERS. How to Catch Trout. Illustrated. Fourth Edition. 16mo. Edin.: D. Dovglas, 1889.

THREE ANGLERS. How to Catch Trout. Illustrated. New Edition. 16mo. Edin.: D. Douglas, 1895.

THREE IN NORWAY. By Two of Them. Map and Fifty-nine Illustrations. 12mo. London: LoNGMans, 1882.

THREE IN NORWAY. By Two of Them. Map and Fifty-nine Illustrations. Third Edition. 12mo. London: Longmans, 1887.

TIMBS (JOHN). Knowledge for the People; or, the Plain Why and Because. Illustrated. 16mo. Boston : Lilly \& W arT, 1832.

TIMES TELESCOPE FOR 1829. Naturalist's Diary, etc. Engravings. 12mo. London: SHERWOOD \& Co., 1829.

TOCQUE (P.) A Peep at Uncle Sam's Farm, Fisheries, etc. Illustrated. 12mo. Boston: Chas. H. PeIrce \& Co., 1851.

TOD (SUETONIUS M.) Sea and Trout Fishing in the Isle of Man. 16mo. N. P.: N. D.

* "Corrected for Glover's Illustrated Guide," 18 ro.

TOLFREY (FREDERIC). Sportsman in Canada. Illustrated. 2 vols. 12mo. London: 'T. C. NewBY, 1845. 
Thunberg 1Chas. P) Orawels in Europe, tfriea, aw Asia 17y0-1779. Engs.

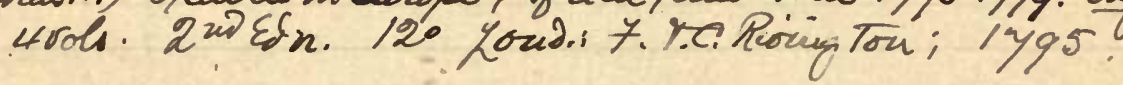


Trimmer, Mrs Mary that ural tisiony of the most Remarkable

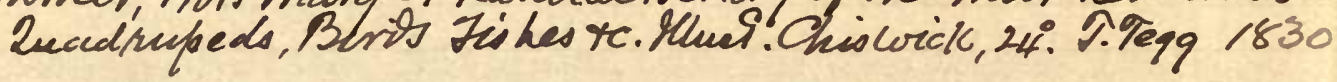


TONKIN (J. C.) and ROW (PRESCOTT). Lyonesse: A Hand-book for the Isles of Scilly. Illustrated. 12mo. London: St. Brides Press, 1900.

TOURICE (MAC). Les Secrets de la Pêche a la Ligne. 24mo. Paris : N. D.

TOURISTS' ILLUS'TRATED HAND-BOOK. For Ireland. Maps and Illustrations. 12mo. Dublin: 1853.

TOWNSHEND (J. K.) Sporting Excursions in the Rocky Mountains. 2 Frontispieces. 2 vols. 12mo. London: H. Colburn, 1840.

TRAHERNE (JOHN P.) The Habits of the Salmon. 12mo. London : Chapman \& Hall, 1889.

TRAVERS (H.) Miscellaneous Poems and Translations. $12 \mathrm{mo}$.

London: Printed for BenJ. Motte, 1731.

TRAVERS (H.) Miscellaneous Poems and Translations. $12 \mathrm{mo.}$ York: Printed by C. Ward and R. Chandler, 1740.

TREASURES OF THE DEEP. Illustrated. 12mo. London: T. NELson \& Sons, 1876.

TRITON FISH AND GAME CLUB, QUEBEC. Prospectus, ByLaws, Notices, etc. 8vo. Quebec: 1898.

TROLLOPE (ANTHONY, Editor). British Sports and Pastimes, 1868. 12mo. London: Virtue \& Co., 1868.

TROUT AND THE BLACK BASS. A Special Illustrated Edition of "The American Angler." 4to. N. Y.: May 1st, 1887.

TUGWELL (REv. GEORGE). On the Mountain. 2 colored lithagraphs. 12mo. London: R. Beniter, 1862.

TUPPER (MAR'IIN F.) Heart: a Social Norel, etc. 12mo. London :

R. Bentley, 1844.

TURNER (L. M.) Contributions to the Natural History of Alaska. 26 plates of Fish and Birds. 4to. Washington : 1886.

TURTON (JOHN). The Anglers' Manual. Front. 16mo. London: R. Groombridge, 1836.

TYSON (T.) Angling: An Illustrated Book on Bottom Fishing, etc. Illustrated. Sq. 24mo. Sheffield: E. E. Weston, (1888).

INITED STATES. Catalogues of the United States Exhibit at the International Fisheries Exhibition, London, 1883. 2 vols. 8vo. Washington : 1884.

UNITED STATES CENSUS June 1, 1890. Statistics of Fisheries. 16mo. Washington: 1890. 
UNITED STATES Comn. of Fish and Fisheries, Reports on. 25 vols. 8vo. Washington: 1873-1900.

UNITED S'TATES FISH COMN. of Fish and Fisheries. Proceedings and Papers of the National Fishery Congress, Tampa, Florida, Jan. 19-24, 1898. Illustrations. 4to. Washington: 1898.

UNITED S'IATES Comn. of Fish and Fisheries. The Preservation of Fishery Products for Food. By Chas. H. Stevenson. Illustrated. 4to. Washington: 1899.

UNITED STATES Comn. of Fish and Fisheries. Investigations of the Aquatic Resources and Fisheries of Porto Rico in 1899. Colored and Plain Plates. 4to. Washington : 1900.

UNIVERSAL ANGLER; or, The Art Improved-Espocially in FlyFishing. Cuts of the Fish. First Edition. 16mo. London : Printed, and sold by all the Booksellers in Town and Country, 1766.

UP DE GRAFF (THAD. S.) Bodines; or, Camping on the Lycoming. Illustrated. 16mo. Phila.: J. B. Lippincott Co., 1879.

UP DE GRAFF (THAD. S.) Camping in the Alleghanies; or, Bodines. Illustrated. Second Edition. 16mo. Phila.: J. B. Lippincotr Co., 1883.

Whenciennes. Cartilages des Poissons. Colored Plates. Folio. Paris: N. D.

* From " Archives du Muséum d'Histoire Naturelle."

VALLOT (J. N.) Ichthyologie Française ou Histoire Naturelle des Poissons D'Eau Douce de la France. Portrait. 8vo. Dijon: E. Fradtin, 1837.

VALUABLE SECRETS Concerning Arts and Trades. Art of Fishing, Angling, etc. 16mo. Dublin: Jas. Wruliams, 1778.

VALUABLE SECRETS in Arts and Trades. Art of Fishing, Etc. 12mo. London: Printed for J. Barker, N. D.

VAN BENEDEN (P. J.) Animal Parasites and Messmates. 83 Illustrations. Second Edition. 12mo. London: H. S. KING \& Co., 1876.

VAN DOREN (LOUIS O.) The Fishes of the East Atlantic Coast, Florida. By S. C. Clarke. Illustrated. 8vo. New York: AmerIOAN ANGLER, 1884.

VAN DYKE (THEO. S.) Flirtation Camp. Rifle, Rod and Gun in California. First Edition. 12mo. New York: Fords, Howard \& HULBERT, 1881. 
Van Syke (tramp LitteReivers. Elahing. $24^{\circ}$ h.Y. Seribuers, 1899 
VAN DYKE (HENRY). Little Rivers. Illustrated. 12mo. New York : Chas. Soribner's Sons, 1895.

VAN DYKE (HENRY). The Builders and Other Poems. $12 \mathrm{mo.}$ New York: Chas. Soribner's Sons, 1897.

VAN DYKE (HENRY). Fisherman's Luck. Illustrated. $12 \mathrm{mo.}$ New York: Chas. Soribner's Sons, 1899.

VAN DYKE (HENRY). Fisherman's Luck. Walton Edition. Japan Proof Illustrations. 8vo. New York: Chas. Soribner's Sons, 1899.

* Limited to 150 copies on Van Gelder paper. No. 23.

VAN NEST (Rev. A. R., D. D.) Memoir of Rev. Geo. W. Bethune, D. D. Portrait. 12mo. New York: Sheldon \& Co., 1867.

VANIERII (JACOBI). Prædium Rusticum. Nova Editio Eæteris Emendatior. Frontispiece. 16mo. Paris: Jos. Barbod, 1774.

VANIER. Fishing. A Translation from the Latin of Vanier. Book $\mathrm{XV}$, Upon Fish. By Rev. John Duncombe. 8vo. London: Printed for R. Triphook, 1809.

"VATES." The Sporting Oracles and Almanack of Rural Life. 12 Illustrations. $16 \mathrm{mo}$. London: A. H. BaILx, 1841.

VENABLES (Cor. ROB'T.) The Experienced Angler; or, Angling Im. proved. Cuts. Fourth Edition. 24mo. London: Printed For Richard Marriot, 1676.

VENABLES (CoL. ROB'T.) The Experienced Angler. Title Engraved and Used as a Frontispiece and Cuts. Fifth Edition. 24mo. London: Printed bx B. W. for B. Tooke \& Thos. Sawbridge, 1683. VENABLES (CoL. ROB'T.) The Experienced Angler. Engravings of Fish. 12mo. London: T. Gosden, 1727.

VENABLES (CoL. ROB'T.) The Experienced Angler. Engravings of Fish. 16mo. London: S. Prowett \& T. Gosden, 1825.

VENABLES (CoL. ROB'T.) The Experienced Angler. Engravings of Fish. 12mo. London: T. GosDen, 1827.

VERMIN (Thi) KILLER. Being a Compleat and Necessary Family Book. 16mo. London: Printed and Sold bY W. Owen. [Circa, 1754.]

VERMIN (The) Killer. Also "The Art of Taking all Kinds of Fish and Fowl," etc. 8vo. Preston: Printed and sold by W. Sergent, N. D.

VERMONT (STATE OF). Report of Commissioners Relative to the Restoration of Sea-Fish to the Connecticut River and its Tributaries. Annnal Session, 1866. 8vo. Montpelier: 1866. 
VERMONT. Report of the Fish Commissioners of the State of Vermont. By A. D. Hager and Chas. Barrett, 1869. 8vo. Montpelier: 1869.

[VICARY (JOHN FULFORD).] A Danish Parsonage. By An Angler. 12mo. London: Keegan PaUl, 1884.

VILLIERS-STUAR'L. Adventures Amidst the Equatorial Forests and Rivers of South America. Illustrations and Maps. 4to. London : John Murray, 1891.

VIRGINIA (STATE OF). Report Fish Commissioners to the Governor of Virginia. Mid-Lothian, Jan. 4, 1872, by Wm. B. Ball. (Sen. Doc. No. VIII.) 8vo. N. P.: 1872.

VIRGINIA. Annual Report of the Fish Commissioners, 1875. 8vo. Richmond : 1875.

VIRGINIA. Annual Reports of the Fish Commissioners. Years 1875-6 and 1876-7. Illustrations. 8vo. Richmond: 1877.

VIRGINIA. Annual Report of the Fish Commissioners, State of Virginia. Year 1877. 8vo. Richmond: 1877.

VIRGINIA. Annual Report of the Fish Commissioner. Year 1878. 8vo. Lexington, Va.: 1878.

VIRGINIA. Annual Report, Commissioners of Fisheries for Virginia, 1883. 8vo. Richmond: 1884.

VOX PISCIS: or, The Book-Fish. Contayning Three Treatises which were found in the belly of a Cod-Fish in Cambridge Market, on Midsummer Eve last, Anno Domini 1626. Frontispieee. 24mo. London : Printed for Jas. Boler and Robert Milbovrne, 1627.

1 ADE (HENRY). Rod-Fishing in Clear Waters, by Fly, Minnow and Worm. Colored Plates of Flies. 16mo. London: Bell \& DALDY, (1860).

WADE (HENRY). Halcyon; or, Rod-Fishing with Fly, Minnow and Worm. Eight Colored Plates. 12mo. London: Bell \& Daldy, 1861.

WALBRAN (FRANCIS M.) Piscatorial Hints, with Catalogue of Salmon, Trout and Grayling Flies, Rods, Reels, etc. Illustra'ed. Fourth Edition. Sq. 8vo. Leeds: 1890.

WALBRAN'S (FRANCIS M.) Angler's Annual, 1894. Illustrated. Sixth Edition. Sq. 8vo. Leeds: 1893.

WALES. Gossiping Guide to Wales. 34 Maps, Plans, etc. $16 \mathrm{mo.}$ New York: Henry Blackwell, Woodside, Long Island, 1889. 

WALKER(PATRICIUS). Rambles. Vignette, Queen's Bower. $12 \mathrm{mo}$. LoNGMANs, 1873.

WALLACE (E. R.) Descriptive Guide to the Adirondacks. Revised. Maps and Illustrations. 12mo. New York and Syracuse: 1875.

WALLWORK (JAMES). The Modern Angler. Copper Engravings. 12mo. Manchester: J As. CheethaM, 1847.

[WALSH (JAS. HENRY).] Angling. By "Stonehenge." (From British Rural Sports, Seventh Edition, pp. 260-310.) Sq. $12 \mathrm{mo.}$ London: F. W ARNE \& Co., 1867.

WALTER (JOHN). Hints to Young Sportsmen; or, the Gun, Saddle and Rod. 8vo. London: R. Barretr \& Sons, 1870.

WALTON (IZAAK) and COTTON (CHAS.) The Compleat Angler. 16mo. London: H. KENT, 1750.

* First Moses Browne Edition.

WALTON (I.) and COTTON (C.) The Complete Angler. Third Hawkins Edition. 8vo. London: Rivington, 1775.

WALTON (I.) and COTTON (C.) The Complete Angler. Fifth Hawkins Edition. 12mo. London: F. \& G. Rivington, 179?.

WALTON (I.) and COTTON (C.) The Complete Angler. Seventh Hawkins, First Bagster Edition. 8vo. London: S. Bagster, 1808.

WALTON (I.) and COTTON (C.) The Complete Angler. Chiswick Edition. Reprint of 1797 edition. 2 vols. 24mo. Chiswick: C. WhitTingham, 1824.

WALTON (I.) and COTTON (C.) The Complete Angler. $16 \mathrm{mo.}$ London: Wm. Cole, N. D. (Circa, 1828)

WALTON (I.) and COTTON (C.) The Complete Angler. 2 vols. 4to. London: Wm. Pickering, 1836.

* Extended to 4 Vols. by the insertion of 366 extra plates.

WALTON (I.) and COTTON (C.) The Complete Angler. Fourth Rennie Reprint of 1833 Edition. 16mo. London: Allan Bell \& Co., 1836.

WALTON (I.) and COTTON (C.) The Complete Angler. 2 vols. in 1. 32mo. London: Chas. Tru't, 1837.

* "Tilt's Miniature Classical Library."

WALTON (I.) and COTTON (C.) The Complete Angler. Edited by John Major. Fourth Edition. 16mo. London: D. Bogue, 1844.

WALTON (I.) and COTTON (C.) The Complete Angler. Sixth Rennie Edition. 16mo. Manchester: S. JoHnson \& Son, 1844. 
WALTON (I.) and COTTON (C.) The Complete Angler. First Bethune Edition. 12mo. New York: Wiley \& Putnam, 1847.

WALTON (I.) and COTTON (C.) The Complete Angler. Third Bethune Edition. 8vo. New York: Wiley \& Putnam, 1852.

WALTON (I.) and COTTON (C.) The Complete Angler. Edited by "Ephemera." Second Edition. 12mo. London: N. Cooke, 1854.

WALTON (I.) and COTTON (C.) The Complete Angler. Reprint of Bohn's 1856 Edition. 12mo. London: Born, 1861.

WALTON (I.) and COTTON (C.) The Complete Angler. 16mo. Boston: TickNor \& FiELDs, 1866.

WALTON and COTTON'S ANGLER. Index to the Original and Inserted Illustrations to Pickering's (1836) Edition. 4to. New York: Privately Printed, 1866.

WALTON (I.) and COTTON (C.) The Complete Angler. 8vo. Boston: LitTle, Brown \& Co., 1866.

* Large Paper. Only 100 printed.

WALTON (I.) and COTTON (C.) The Complete Angler. 16mo. Boston: Little, Brown \& Co., 1867.

WALTON (I.) and COTTON (C.) The Complete Angler. 12mo. London: A. Murray \& Son, 1869.

WALTON (I.) and COTTON (C.) The Complete Angler. Edited by E. Jesse and H. G. Bohn. 12mo. London: Bell \& DALdx, 1870.

WALTON (IZAAK). The Compleat Angler. Facsimile Reprint First Edition, 1653. 12mo. London : Elliot Stock, 1876.

* Large Paper.

WALTON (IZAAK). The Compleat Angler. 16mo. London: E. Stock, N. D. (1880)

* Facsimile Edition.

WALTON (I.) and COTTON (C.) The Complete Angler. 2 vols., 8vo. New York: WILEY \& Sons, 1880.

* Bethune's Edition, Corrected, Large Paper.

WALTON (I.) and COTTON (C.) The Complete Angler. 8vo. Philadelphia: J. B. LipPincotT \& Co., (1881)

* Edition of 250 . No. 42.

WALTON (IZAAK). The Compleat Angler. 16mo. London : Wildiam Griges, (1881)

* Facsimile of the First Edition.

WALTON (I.) and COTTON (C.) 'The Complete Angler. Major's Edition. 4to. London: Nimmo, 1885.

* Large paper. Only 120 printed. No. 86. 


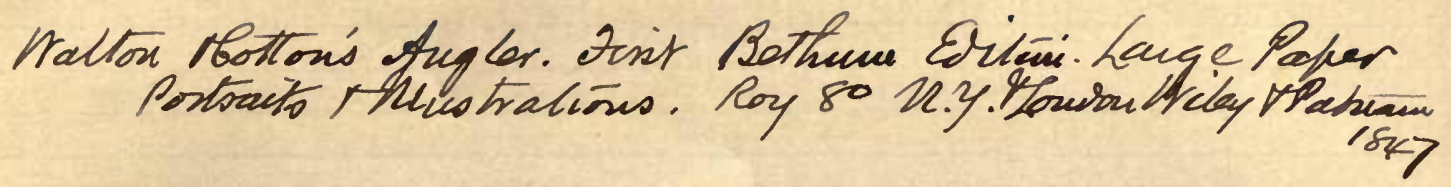


Wallou (Ozaak) Complate Angler Eried Wict an hno metion by Eq. Johuson

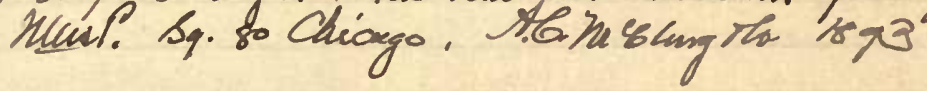

Waltou (dzacak) Lives of Dome, Wotton, Hooker, Alerbert, Sanderson Porvaits. 160 London: Sény Násbourne $184 y$

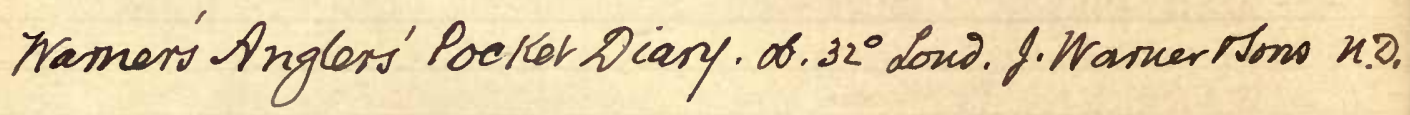


WALTON (I.) and COTTON (C.) The Complete Angler. $12 \mathrm{mo.}$ London: Chatto \& Windus, 1887.

WALTON (I.) and COTTON (C.) The Complete Angler. 2 vols. 4to. London: SAMPSON Low, 1888.

* Lee \& Dove Edition, Demy 4to., 500 printed, No. 122.

WALTON (I.) and CO'TTON (C.) The Complete Angler. 8vo. London : Nтммо, 1889.

WALTON (I.) and COTTON (C.) The Complete Angler. 2 vols., 8vo. Boston: LitTtle, Brown \& Co., 1889.

* Lowell Edition. 500 printed No. $25 \%$.

WALTON (IZAAK). The Complete Angler. 16mo. New York : BaKer \& TAYLOR, 1889.

* Facsimile of First Edition.

WALTON (IZAAK). The Compleat Angler. A New Edition. Edited with an Introduction by Andrew Lang. Illustrated by $E$. $J$. Sullivan. 12mo. London: J. M. Drent \& Co., 1896.

WALTON (IZAAK). The Compleat Angler. Portrait and Cuts of Fish. Miniature Edition ( $1 \frac{7}{8} \times 2 \frac{1}{16}$ inches). London: HENRY Frowde, N. D.

WALTON (IZAAK). Lives of Donne, Wotton, Hooker, Herbert and Sanderson. 16mo. London: J. MAJOR, 1825.

WALTON (IZAAK). Lives of Donne, Wotton, Hooker, Herbert and Sanderson. Portraits. 48mo. London: W. Prokering, 1827.

WALTON AND COTTON CLUB. Rules and Regulations. Illustrated. Sq. $12 \mathrm{mo}$. London: 1840.

WALTON AND CO'TTON CLUB. Rules and Regulations. Instituted 19th March, 1817. Revised 8th April, 1840. Plates inserted. Sq. 12mo. London : 1840.

[WALTON (R.)] A Tour on the Banks of the Thames from London to Oxford. By a Pedestrian. 16mo. London: Hord, 1834.

WARNER (CHAS. DUDLEY). In the Wilderness. 16mo. London : SAMPSON Low, 1878.

WARNER (CHAS. DUDLEY). In the Wilderness. 24mo. Boston : Hovghton, Osgood \& Co., 1879.

WARNER (CHAS. DUDLEY). In the Wilderness. 16mo. Boston and New York. Hovanton, M. \& Co., 1886.

WARREN (MATTHEW H.) Lecture on Newfoundland and Its Fisheries. 8vo. St. Johns: 1853.

WARREN (T. ROBINSON). Shooting, Boating and Fishing. Illustrations. 12mo. New York: Chas. Scribner \& Co., 1871. 
WASHINGTON COUNTY RAILROAD MONTHLY. 2 vols. Narrow 8vo. Calais, Maine : 1899-1901.

WASHINGTON NUMBER OF MAGAZINE OF AMERICAN HISTORY. Illustrated. Edited by Mrs. Martha J. Lamb. Sq. 8vo. New York: 1888.

* Contains "Washington as an Angler."

WATERTON (CHAS.) Wanderings in South America. Engraving of a Nondescript. Fourth Edition. 16mo. London: B. Fellowes, 1839.

WA'TERTON (CHAS.) Wanderings in South America. New Edition. Edited by Rev. J. G. Wood. 100 Illustrations. 12mo. London: Macmillan, 1879.

WATKINS (REv. M. G.) In the Country. 12mo. London: W. Satchell \& Co., 1883.

[WATMOUGH (EDMD. C.]) Scribblings and Sketches, Diplomatic, Piscatory and Oceanic. Second Edition. 12mo. Phila.: C. Suerman, 1844.

WATSON, (A. E. 'T., Editor). The Year's Sport for the Year 1885. 8vo. London : Longmans, 1886.

WATSON (B. A.) The Sportsman's Paradise; or, 'The Lake Lands of Canada. Illustrations and Map. 8vo. Phila.: J. B. Lippincont Co., 1888.

WATSON (JOHN). Sketches of British Sporting Fishes. Front. $12 \mathrm{mo}$. London: Chapman \& Hali, 1890.

WAY'TH (C.) Trout Fishing; or, The River Darent. 8vo. London : Simpkin, Marshall \& Co., 1845.

WEBBER (C. W.) Romance of Sporting. Colored illustrations. 4 to. Phila.: I. W. Bradley, (1851.)

WEBSTER (DAVID). The Angler and the Loup-Rod. Portrait and Illustrations. 12mo. Edin. and London: W. Blackwood \& Soss, 1885.

[WEIDMEYER (M. C.)] American Fish and How to Catch Them. By an Old Angler. Sq. 12mo. New York: F. P. H ARPer, 1885.

WELD (CHAS. RICH'D). Vacations in Ireland. Frontespiece. $12 \mathrm{mo}$. London: Longmans, 1857.

WELLS (HENRY P.) Fly-Rods and Fly-Tackle. Illustrations Sq. 12mo. New York: Harpers, 1885.

WELLS (HENRY P.) Fly-Rods and Fly-Tackle. Illustrated. Sq. 12mo. London: Sampson Low, N. D., (1885). 

Whed uright H.M. Bies hwauderings of a Naturulist. By an Old Bushmaw. 18० Lhud: Roulletge, is6. 
WELLS (HENRY P.) The American Salmon Fisherman. Illustrated. Sq. 12mo. New York: Harpers, 1886.

WELIS (HENRY P.) Fly-Rods and Fly-Tackle. Illustrated. Sq. 12mo. New York: Harpers, N. D.

WELLS (JOSEPH). 'The Temperance Fishing Book; or, The Contemplative Angler. Second Edition. Front. of Hooks. $24 \mathrm{mo}$. Sheffield: Printed at the Independent Office, 1853.

WELLS (WM. V.) Explorations and Adventures in Honduras. Maps and Illustrations. 8vo. New York: Harpers, 1857.

WEST BUCKLAND Year Book and Kalendar for 1857. Illustrations. 8vo. South Molton: W. Tucker, 1857.

WESTWOOD (THOS.) The Chronicle of the "Compleat Angler." Sq. 8ro. London: Willis \& Sotheran, 1864.

WESTWOOD (THOS.) The Chronicle of the "Compleat Angler." A New Edition with additions by Thos. Satchell. Sq. 8vo. London: W. Satchell, 1883.

WESTWOOD (T.) In Memoriam. Izaak Walton, Obiit 15th December, 1683. Twelve Sonnets and an Epilogue. Sq. 8ro. London: W. SATCHELL, N. D.

WHEA'TLEY (HEWE'T'). Rod and Line; or, Practical Hints and Dainty Devices for the Sure Taking of Trout, Grayling, etc. Colored plates of Flies. 16mo. London: Longmans, 1849.

WHEELDON (J. P.) Angling Resorts near London. Portrait inserted. 12mo. London: TRÜBNER, 1878.

WHEELDON (J. P.) Angling Clubs and Preservation Societies of London and the Provinces. 8vo. London: W. Clowes \& Sons, 1883.

*Bound in "Angling Clubs, by J. Skinner," Prize Essay. London : 1884.

WHEELDON (J. P.) Practical Lessons in the Gentle Craft. 8vo. (London: 1888).

WHEELDON (J. P.) Sporting Facts and Fancies. 12mo. London: For the Author, 1894.

WHEELER (OLIN D.) Wonderland '98. Illustrated. Sq. 8vo. St. Paul : Nortirern Pacifio Railway, 1898.

[WHEELWRIGHT (HORACE WM.)] Sporting Sketches at Home and Abroad. By the Old Bushman. Illustrations. 12mo. London : F. W ARNE \& Co., N. D.

WHISTLE-BINKIE. A Collection of Songs for the Social Circle. Five series in 2 vols. 24mo. Glasgow: David Robertson, 1842-46. 
WHITCHER (W. F.) Nepigon Trout. An Ottawa Canoeist's experience on the Northern Jake Superior. Illustrated. Sq. $16 \mathrm{mo.}$ Montreal: Canadian Pacific R. R., 1887.

WHITE (REv. GILBERT). A Naturalist's Calendar. Never before published. Frontispiece of the curious Hybrid Bird, colored. 8vo. London: B. \& J. W HITE, 1795.

WHITE (REv. GILBERT). Natural History of Selborne. A New Edition, with engravings. 2 vols. 8vo. London: White, Cochrane \& Co., 1813.

WHITE (REv. GILBERT). Natural History of Selborne. A new Edition. Notes by Edward Blythe. Illustrations. $16 \mathrm{mo}$. London: Orr \& SмItH, 1836.

WHI'TE (REv. G.) Natural History of Selborne. 40 engravings. 16mo. London: H. G. BoHs, 1851.

WHITE (REv. G.) Natural History of Selborne. Notes by Rev. J. G. Wood. Engravings. 16mo. London: Routledge, 1854.

WHITE (REv. G.) Natural History of Selborne. Edited by E. Jesse. Engravings. 12mo. London: G. Ber.L \& Sons, 1878.

WHITE (Rev. G.) Natural History of Selborne. 16mo. London: ROUTLEDGe's WorLd Library, 1886.

WHITE (REv. G.) Natural History and Antiquities of Selborne. Revised, with notes by J. E. Harting. Seventh Edition. Engravings by Bewick, etc. 8vo. Philadelphia: Grbbie \& Co. 1889.

WHI'TE (REv. GILBER'T). Natural History of Selborne. Edited with Notes by G. Christopher Davies. Illustrated. 12mo. London and New York: F. W ARNE \& Co., N. D.

WHITE (J.) Hocus Pocus; or, A Rich Cabinet of Legerdemain, Curiosities, etc. 40 Curious Cuts. 24mo. London: Sold at the Ring in Litrule Britain, etc., N. D.

[WHITE ( ).] Sporting Scenes and Country Characters. By Martingale. (pseud.) Illustrations. Sq. 12mo. London: Longmans. 1840.

[WHITE ( ).] English Country Life. By Martingale. (pseud.) 12mo. London: R. Bentley, 1843.

WHITEHURST (FRED FIELD). On the Grampian Hills. Salmon and Trout Fishing etc. 12mo. London: Tinslex Bros., 1882.

WHITNEY (JOHN). The Genteel Recreation; or, The Pleasure of Angling. A Poem. 16mo. London: Printed in the Year 1700.

* One hundred copies for J. H. Burn, 1820. 
Irhite (Walter) All Around The Trelcin Post 80 London: Chapman strall 1860 

WHOLE (THE) Art of Fishing and the Laws of Angling. Frontispiece. 12mo. London: Printed for E. Curll, 1714.

WILCOCKS (J. C.) The Sea-Fisherman, or Fishing Pilotage. Over 100 Engravings. First Edition. 12mo. Guernsey: S. BARBET, 1865.

WILCOCKS (J. C.) Sea-Fisherman. Second Edition. Almost entirely rewritten, and enlarged. Illustrated. 12mo. London: Longmans, 1868.

WILCOCKS (J. C.) Sea-Fisherman. Fourth Edition. Illustrated. 12mo. London: Longmans, 1884.

WILCOX (WALTER DWIGHT). The Rockies of Canada. Over 40 Photogravures and other Illustrations. 8vo. New York and London: Putnams, 1900.

WILLARD (CAPT'N. BEN'J. J.) Captain Ben's Book. Pilot and Stevedore. Illustrated. 8vo. Portland, Me.: 1895.

WILLIAMS (F. 'T.) Angler's Pocket Diary and Monthly Guide. Vignette of the Silver Trout. $16 \mathrm{mo}$. London: 1867.

WILLIAMSON (JOHN). The British Angler: or, A Pocket-Companion for Gentlemen-Fishers. Copper Plates. 16mo. London: J. Hodges, 1740 .

WILLIAMSON (CAPTAIN THOS.) Oriental Field Sports. Jrawings by Samuel Howitt (Colored.) 2 vols., 4to. London. E. Orme. 1807. WILLIAMSON (Captain T.) The Complete Angler's Vade Mecum. Engravings. 8vo. London: Payne \& Mackinlay, 1808.

WILLIS (N. P.) Al'Abri, or the Tent Pitch'd. 12mo. New York: Sam's Colman, 1839.

WILLIS (N. PARKER). Rural Letters. First Edition. 12mo. New York: BAKER \& ScribNER, 1849.

WILLIS-BUND (J. W.) Salmon Problems. 12mo. London : Sampson Low, 1885.

WILMOT (SAMUEL). Report on Fish-Breeding Operations in the Dominion of Canada during the year 1881. Svo. Ottawa: Maclean ROGER \& Co., 1882.

WILLOUGHBY (FRANCIS). De Historia Piscium Libri Quator, Jussu and Sumptibus Societatis Regiæ Londonensis Editi. Old Engravings. Folio. Oxonii: E. Theatro Sheldoniano, Anno Dom., 1686.

WILSON (ANDREW). Sketches of Animal Life and Habits. 1 llustrated. 16mo. London and Edinburgh : 1877. 
WILSON (JAS.) An Introduction to the Natural History of Fishes. From the 7th Edition of the Encyclopædia Britannica. Plates. 4to. Edin. A. \& C. Black, 1838.

WILSON (JAMES). The Rod and the Gun. Engravings. $12 \mathrm{mo.}$ Edinburgh : A. \& C. Black, 1840.

WILSON (JAS.) A Voyage Round the Coasts of Scotland and The Isles. Illustrations, 1 Map. 2 vols. in 1. 12mo. Edinburgh : A. \& C. BLACK, 1842.

WILSON (JAS.) The Rod and the Gun. New Edition. Illustrations. 12mo. Edinburgh : A. \& C. Black, 1844.

WILSON (JOHN). The Isle of Palms and other Poems. First Edition. 8vo. Edin.: Longmans, 1812.

WILSON (JOHN). Poems by. A new Edition. 2 vols. 12mo. Edin. and London : 1825.

[WILSON (PROF. JOHN)]. The Recreations of Christopher North.

3 vols. 12mo. Edinburgh and London : 1842.

WILSON (PROF. JOHN). Noctes Ambrosianæ. Revised Edition. Memoirs and Notes, by R. Shelton MacKenzie. Portrait. 5 vols. 12mo. New York: W. J. Wrddleton, 1863.

WILSON (SIR SAMUEL). Salmon at the Antipodes. Map and Front. 12mo. London: E. Stanford, 1879.

WISCONSIN CENTRAL RAILROAD. Noted Pleasure and Summer Resorts of Wisconsin and Lake Superior. Illustrated. $12 \mathrm{mo.}$ Milwaukee: N. D.

WOOD (ARNOLD). A Bibliography of "The Complete Angler" of Izaak Walton and Charles Cotton. 4to. New York: Chas. Scribner's Sons, 1900.

* Of this Edition on Van Gelder paper, only 102 copies were printed, No. 29.

WOOD (J. G.) Illustrated Natural History. Reptiles, Fishes, Molluscs, etc. Illustrated. 4to. London and N. Y. (1863).

WONDERS of Marine Life. 25 Illustrations. 12mo. Boston and New York: D. Appleton \& Co., (1894).

WOODCRAFT MAGAZINE. Vol. 1. 8vo. New York: Forest and Stream, 1900.

WOODCRAFT. Game Laws in Brief and Woodcraft. Illustrated. Vol. II. 8vo. New York : Forest and Stream, 1900-1.

WOOLSEY (CHAS. WM.) A Fishery Imbroglio. Sq. 16mo. New York: Art Age Press, 1886. 

- Young, Atthur. Fravels in Trance 1787-1289. Maps $2 v 6$ so Oubliv Pruetes for Hiceir Cros, Wogou re. 1799

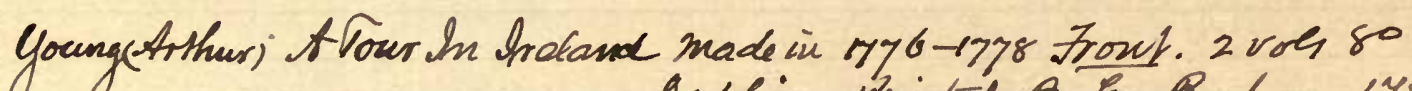
Sheblice: Brinted By Geo-Boxham 11980 
WORLYDGE (J.) Systema Agriculturæ. Second Edition. Frontispiece. 4to. London: 1675.

WRIGHT (W.) Fishes and Fishing. Artificial Breeding of Fish, etc. Illustrations. 16mo. London: T. C. Newbr, 1858.

WYATT (THOS.) A Synopsis of Natural History. Plates of Fish, etc. 8vo. Phila.: 1839.

ARRELL (WM.) A History of British Fishes. Illustrated by nearly 400 Woodcuts. 2 vols. 8vo. London: J.VAN Voorst, 1836.

YARREL (WM.) On the Growth of the Salmon in Fresh Water. Six Colored Illustrations of the Fish. Oblong 4to. London: J. VAN Voorst, 1839.

"YELLOW BODY." Angling Days on Scotch Lochs. By "Yellow Body." 12mo. Edinburgh : J. Menzies \& Co., 1884.

YOUNG (ANRDEW). The Natural History and Habits of the Salmon. 16mo. London: Longmans, 1854.

YOUNG (ANDREW). Angler and Tourist's Guide. Map. 24 mo. Edin.: A. \& C. Black, 1857.

YOUNG (ARCHIBALD). Angler's and Sketcher's Guide to Sutherland. Map. 16mo. Edinburgh: W. Paterson, 1880.

YOUNG (ARCHIBALD, Advocate). The Angler's and Sketcher's Guide to Sutherland. Map. Second Edition. 16mo. Edinburgh : WM. Paterson, 1881.

YOUNG (LAMBTON J. H.) Sea-Fishing As a Sport. Illustrated. 12mo. London: Groombridge \& Sons, 1865.

YOUNG (L. J. H.) Sea-Fishing As a Sport. Colored Plates of Fish, etc. Second Edition. 12mo. London: Groommridge \& Sons, 1872.

YOUNG (Тне) Angler, Naturalist, etc. 98 illustrations. 16mo. London: Routleder, 1860.

YOUNG (TнE) Angler's Companion. 50 Engravings. Printed and Published by Jas. March. 16mo. London: N. D.

YOUNG (TнE) Angler. Containing Instructions for Preparing Rods, Lines, Reels, Hooks, Baits, etc. Illustrated. 16mo. New York: N. D.

YOUNG (Tнe) Fisherman, A Complete Guide to Angling. 12mo. London : H. Elliot, N. D. 
YOUNG SPORTMAN'S Miscellany in Hunting, Shooting, Racing, Coursing, Angling, Cocking, etc. Including a reprint of Barker's Scarce Tract on Angling. Front and 22 fine Woodcuts. $24 \mathrm{mo}$. London: Сомpton \& Ritchie, 1826.

YOUNGER (JOHN). On River Angling for Salmon and Trout. First Edition. 32mo. Edinburgh: W. Black wood \& Sons, 1840.

YOUNGER (JOHN). River Angling for Salmon and Trout. Portrait. 16mo. Kelso: J. \&. J. H. Rutherfurd, 1860.

YOUNGER (JOHN). River Angling for Salmon and Trout. Portrait. 16mo. Kelso: J. \& J. H. Rutherfurd, 1864. 


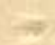

$-90+2+2+2$ 







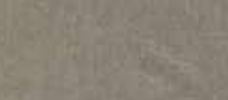

6.

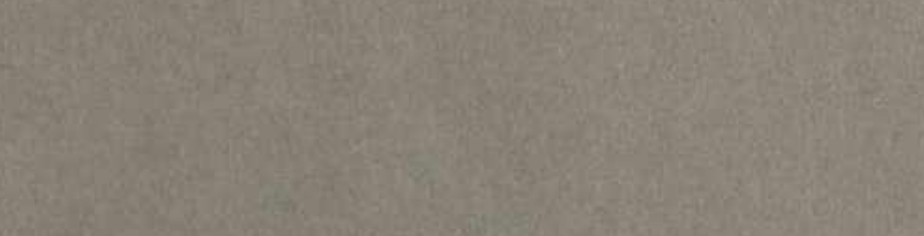

19.

WaYSE

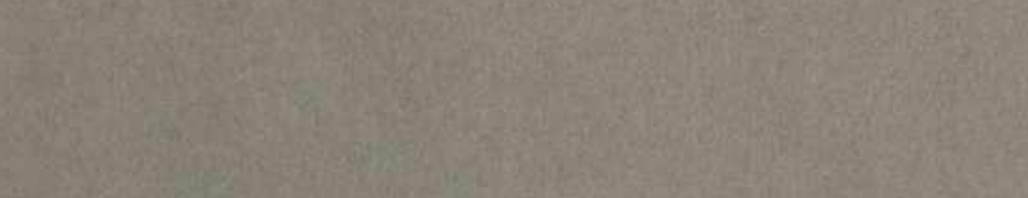
-

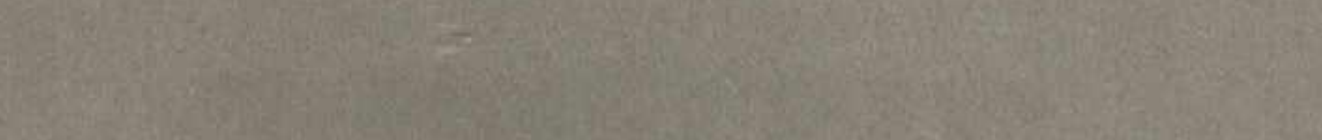
4.

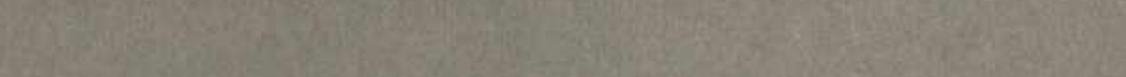
(7.

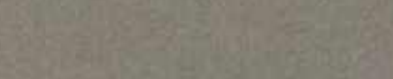
8. Ii

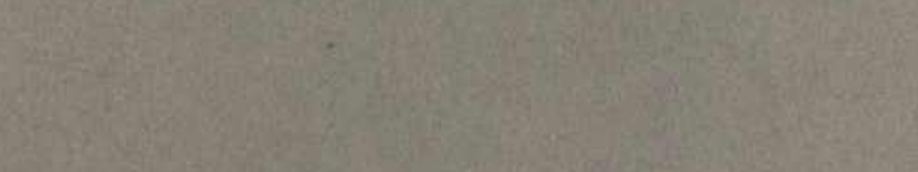

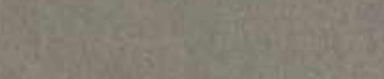
1.

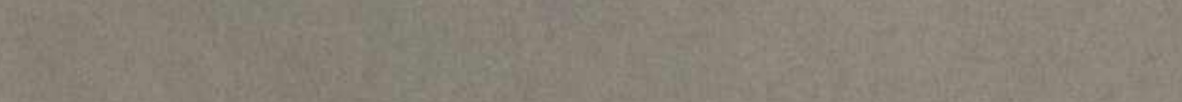

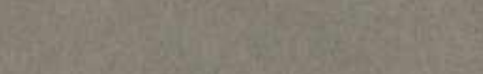

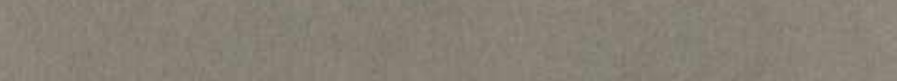
G.

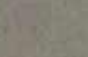
ation

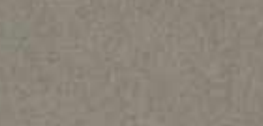
SThe

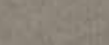
Thising

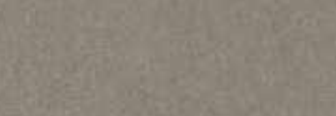
ing

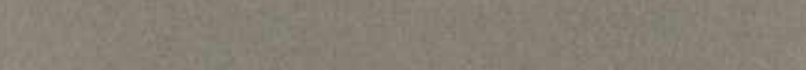

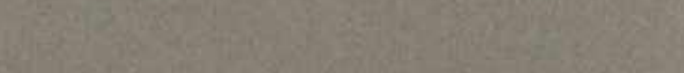
10.

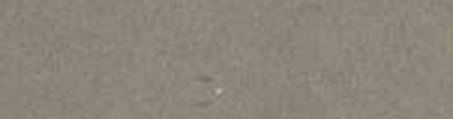
(3) y. wh at is

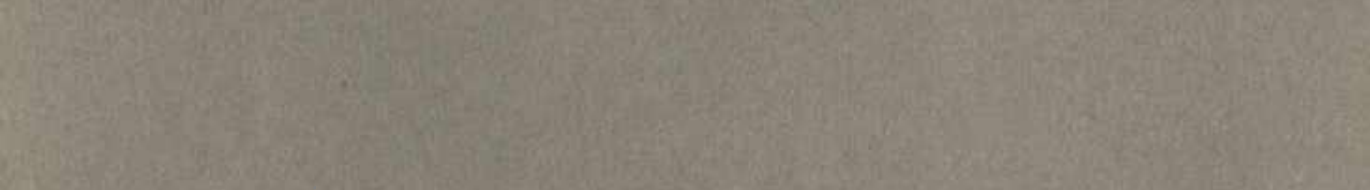

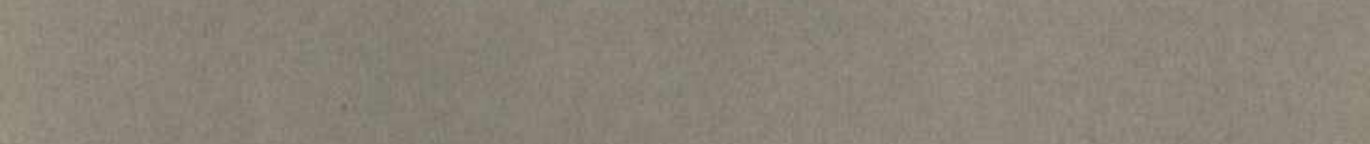

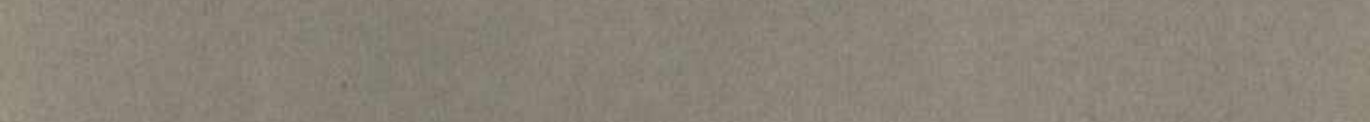
Whin

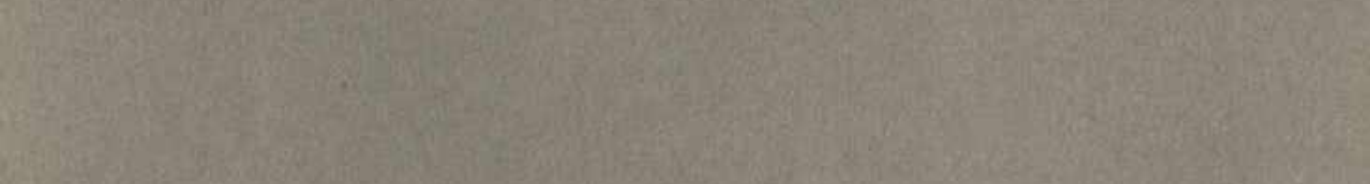
$y_{1}=4$

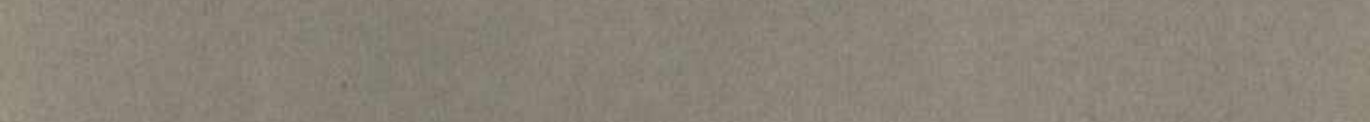

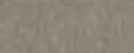
$x_{1}=x^{2}=3$ (8) Wing

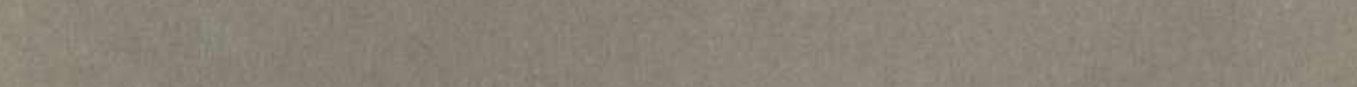

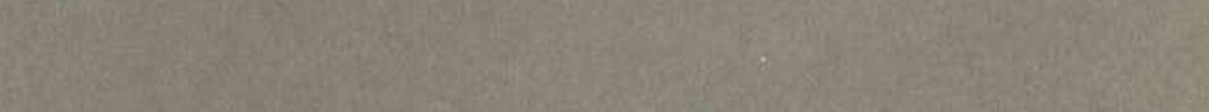

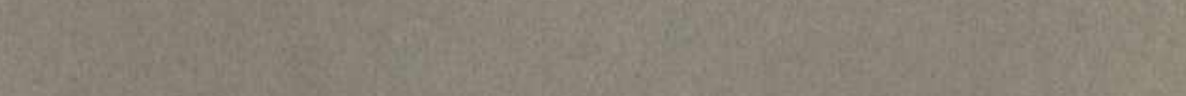
(ix) 
RETURN TO the circulation desk of any University of California Library or to the

NORTHERN REGIONAL LIBRARY FACILITY

Bldg. 400, Richmond Field Station

University of California

$-$

Richmond, CA 94804-4698

- ALL BOOKS MAY BE RECALLED AFTER 7 DAYS

- 2-month loans may be renewed by calling (510) 642-6753

- 1-year loans may be recharged by bringing books to NRLF

- Renewals and recharges may be made 4 days prior to due date.

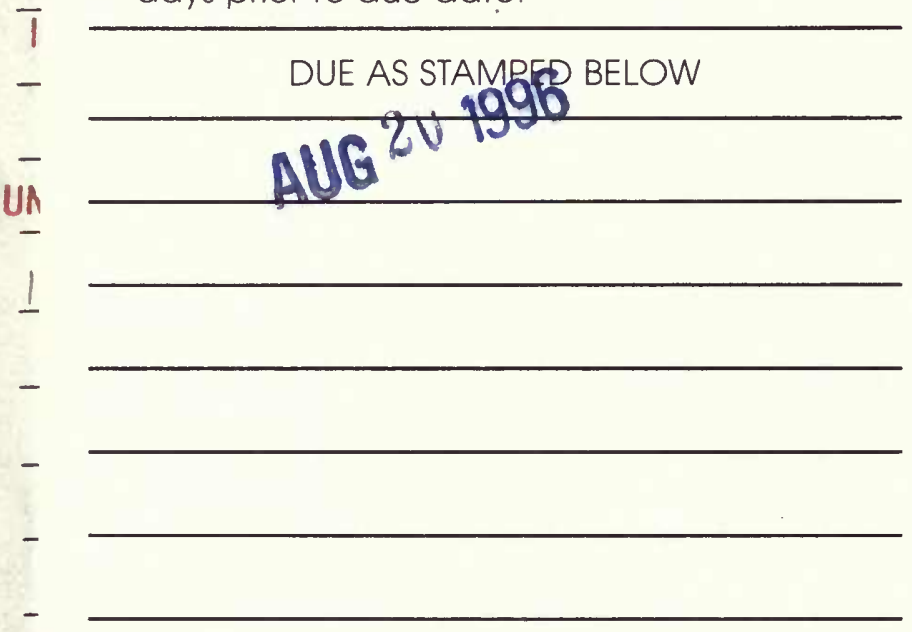





$$
=
$$

